E. J. CROSSMAN CHERYL D. GOODCHILD

\section{An Annotated Bibliography of the Muskellunge, Esox masquinongy (Osteichthyes: Salmoniformes)}

Publication date: 28 February 1978

ISBN 0-88854-208-9

ISSN 0082-5093

Suggested citation: Life Sci. Misc. Pub., R. Ont. Mus. 


\section{ROYAL ONTARIO MUSEUM \\ PUBLICATIONS IN LIFE SCIENCES}

The Royal Ontario Museum publishes three series in the Life Sciences:

LIFE SCIENCES CONTRIBUTIONS, a numbered series of original scientific publications including monographic works.

LIFE SCIENCES OCCASIONAL PAPER, a numbered series of original scientific publications, primarily short and usually of taxonomic significance.

LIFE SCIENCES MISCELLANEOUS PUBLICATIONS, an unnumbered series of publications of varied subject matter and format.

All manuscripts considered for publication are subject to the scrutiny and editorial policies of the Life Sciences Editorial Board, and to review by persons outside the Museum staff who are authorities in the particular field involved.

\section{LIFE SCIENCES EDITORIAL BOARD}

Chairman: A. R. EMERY

Senior Editor: A. G. EDMUND

Editor: A. J. BAKER

Editor: J. H. MCANDREWS

E. J. CROSSMAn is Curator in the Department of Ichthyology and Herpetology, Royal Ontario Museum, and Professor in the Department of Zoology, University of Toronto.

CHERYL D. GOodCHILD is a Curatorial Assistant in the Department of Ichthyology and Herpetology, Royal Ontario Museum.

\section{LIERTRYY}

\section{OYAL: ONTARIO MUSEUN}

PRICE: $\$ 4.50$

(C) The Royal Ontario Museum, 1978

100 Queen's Park, Toronto, Canada M5S 2C6

PRINTED IN CANADA AT THE ALGER PRESS 


\section{Contents}

Introduction 5

Acknowledgements 10

Annotated Bibliography 14

Index by Subjects

Accounts by Geographical and Political Areas 115

Age and Growth 115

Anatomy 116

Angling and Record Catches 116

Behaviour 118

Commercial Fishing 118

Creel Census 119

Culture and Artificial Propagation 119

Dingell-Johnson Project Reports 120

Distribution and Range 121

Food and Feeding Habits 123

Fossils 123

General Accounts 123

Habitat and Environmental Factors 123

Hybrids 124

Introduction and Stocking 124

Length-Weight Relationships 125

Life History and Habits 125

Management (general) 125

Marking and Tagging 126

Parasites, Diseases, Pathology 127

Physiology 127

Popular Accounts 127

Population Studies 129

Predator-Prey Relationships 130

Proteins, Enzymes, Electrophoresis 130

Spawning (natural) 130

Taxonomy, Nomenclature, Systematics 131 
Digitized by the Internet Archive in 2012 with funding from Royal Ontario Museum 


\section{An Annotated Bibliography of the Muskellunge, Esox masquinongy (Osteichthyes: Salmoniformes)}

\section{Introduction}

The muskellunge, the largest species in the family Esocidae, is endemic to the fresh waters of North America and has the most restricted distribution of the five native North American esocids. There are many unauthenticated stories of catches in the late $1800 \mathrm{~s}$ and early $1900 \mathrm{~s}$ of individuals weighing more than 100 pounds $(45 \mathrm{~kg}$ ). The present angler record stands at 69 pounds, 15 ounces $(31.7 \mathrm{~kg})$. The muskellunge was 64.5 inches $(163.8 \mathrm{~cm})$ in length and 31.75 inches $(80.6 \mathrm{~cm})$ in girth, and was caught in September 1957 by Arthur Lawton, in the St. Lawrence River.

The recent North American distribution extended from the St. Lawrence River near Quebec City, south through western Vermont, west of the Appalachian Mountains (except in Pennsylvania, where it had been introduced east of the mountains), to the Tennessee River system in Tennessee (and probably extreme northern Alabama at one time), northeast through Kentucky and eastern Ohio, around the southern periphery of lakes Erie, Huron, and Michigan, to the stem of the Mississippi River in Iowa, north through Wisconsin and eastern Minnesota to southeastern Manitoba and the Lake of the Woods-Rainy Lake region of Ontario, south around Lake Superior, north to Chapleau, Ontario, and east through Ontario and Quebec to the St. Lawrence River. In the last few years the muskellunge has been introduced into impoundments to the east and to the west of the distribution just described. The introductions in the past have often been unsuccessful (Scott and Crossman, 1975).

In certain water systems in North America the muskellunge is the only esocid. In other North American systems it occurs in the same waters as the northern pike, Esox lucius. In the latter systems natural hybrids are known and the populations of muskellunge are often less successful.

Until the early 1900 s muskellunge were taken commercially by both net fishermen and hook-and-line fishermen, but the species is now strictly a sport fish over the whole of its distribution. Because the muskellunge takes a long time (three to five years) to reach sexual maturity, in many areas it is the only sport fish protected by local minimum-length regulations.

Except for salmons and trout, probably no North American freshwater sport fish is more subject to angler mystique and avid pursuit. The great attraction is not only the potential size of an individual but the legendary struggle, spectacular acrobatics, and strength of a hooked muskellunge. The capture of a legal muskellunge can require as many as 100 man-hours of angling. Anglers who fish almost exclusively for this species are organized into clubs and associations that support hatchery and liberation programmes, study groups, extensive record keeping, and number and weight competitions. These organizations often require that their members release even legal-sized muskellunge. 
Literature references in this bibliography were drawn from a file accumulated over 24 years in the Department of Ichthyology and Herpetology at the Royal Ontario Museum, in conjunction with studies of esocid fishes. To those we have added references provided by a number of biologists and muskellunge anglers.

In response to a growing interest in the welfare and pursuit of the muskellunge, and to increasing requests for access to the file, it seemed appropriate to publish this bibliography. (See also Crossman, E. J. and G. E. Lewis. 1973. An annotated bibliography of the chain pickerel, Esox niger (Osteichthyes: Salmoniformes). Life Sci. Misc. Publ., R. Ont. Mus., 81 pp.)

The bibliography is intended simply as a source book of available publications for anyone interested in the muskellunge from either a professional or a recreational standpoint. It does not attempt to evaluate various papers, especially since many were not seen. A number of references for which citations could not be completed with the aid of bibliographic tools or by correspondence appear in incomplete form. We thought it better to include references to works we knew existed rather than to leave them out because we could not determine year, volume, or pagination, and we do not imply that the bibliography is complete. We hope that those who use it will bring errors and omissions to our attention. If there is a response, and interest in the literature continues, a future update might be appropriate. A revision could be completed with a minimum of effort since this bibliography (like that for $E$. niger) was prepared using the labour-saving Norfield Copystrip system (see Crossman and Goodchild, 1973, Scholarly Publishing 4(3): 245-249).

Wherever possible, publications listed were examined directly in order to assure accuracy of the citation and to prepare an annotation. When this was not possible, we checked the citation in standard bibliographic aids or asked the author or agency concerned to verify it. The intensive search for references from bibliographic aids and literature citation sections of publications, and by contact with authors, ended in June 1976.

Annotations for the large number of references had to be brief. They vary from abbreviated and paraphrased versions of authors' abstracts, to copies of short abstracts from abstracting periodicals, to simple statements of content. Absence of annotation indicates one or both of the following: the article was not examined, though a concerted effort was made to acquire it, or it appeared in an angling periodical and was judged not to require annotation.

When information on the muskellunge is limited to only a few pages in a lengthy publication, the numbers of the pages that make specific mention of the muskellunge are included in the annotation.

For books that have appeared in several, unchanged editions, we attempted to cite only the most recent edition. If there have been changes in title or authors, or significant changes in the discussion of the muskellunge, then more than one edition is cited.

In dealing with numerous citations, the most appropriate format is the briefest one that will be as free as possible of ambiguous abbreviations. For abbreviations we followed the BIOSIS 1972 List of Serials with Coden, Title Abbreviations, New, Changed and Ceased Titles (Biosciences Information Service of Biological Abstracts). The use of abbreviations deviates from the policy for recent ROM publications but was adopted in order to save space in a publication consisting almost exclusively of citations. 
The body of the bibliography is arranged alphabetically by author and chronologically for authors with more than one publication listed. If the reader is searching for details of a citation for which he knows the author's name, he can refer directly to the body of the bibliography.

The subject index that follows the bibliography attempts to organize the subject matter dealt with in the individual publications. It lists alphabetically, under each subject heading, the authors' names and publication dates for all applicable publications in the bibliography. The complete reference, and annotation when provided, can then be sought in the body of the bibliography.

Subject categories were chosen on the basis of the subject matter represented by the accumulated references, but were given titles that we felt would best represent subject areas users would most naturally look for. There is a moderate amount of crossindexing in order to include in the subject index articles that treat several subjects, or involve an area that encompasses more than one of the subject categories. The subject categories of the index as are follows:

1. Accounts by Geographical and Political Areas-includes mainly publications entitled "The fishes of" a particular area. Such accounts usually involve at least brief comments for the species on several subjects. References in this category are not cross-indexed unless the account includes a significant contribution to one or more of the other categories. It is in publications indexed in this category that the reader will find at least basic information on the muskellunge in his specific region, province or state.

2. Age and Growth-publications dealing with the determination and interpretation of these subjects. Includes papers on techniques associated with the determination of age. Papers that deal with the relationship of length and weight without associating them with age are indexed under "17. Length-Weight Relationships".

3. Anatomy - this broad category was established to include the few but diverse papers on external anatomy, internal anatomy, osteology, and studies of structures that might otherwise be listed under embryology and cytology. It does not include references to works listing anatomical features as a part of a simple description of the animal.

4. Angling and Record Catches-includes stories and reminiscences about angling for the species and notices of record catches. Most often these are articles in outdoor magazines, popular books, and periodicals.

5. Behaviour-includes only those references dealing with ethological studies. Concepts of behaviour, often referred to as habits, are included under "18. Life History and Habits".

6. Commercial Fishing-articles dealing with the capture of the muskellunge for sale. Government publications listing commercial fisheries catches were not included in the bibliography. Anyone interested in this type of information should check federal, provincial, or state government reports, such as Reports of the Commissioner of Fisheries, Annual Reports, and Overseers' Reports. Government departments are frequently reorganized and therefore these reports can be found under various department names throughout the years.

7. Creel Census - although often allied to "2. Age and Growth" and "24. Population Studies", articles on creel censuses do not always indicate the intended application of the data and so they are indexed separately. 
8. Culture and Artificial Propagation-includes references to works dealing with artificial spawning, hatching, and rearing. Natural spawning was included here only if the information was provided as an adjunct to artificial culture. Otherwise articles on natural spawning are indexed under "27. Spawning (natural)". Discussions of hybrids cultured in the laboratory or hatchery are included in "15. Hybrids".

9. Dingell-Johnson Project Reports-these reports of projects supported under U.S. federal aid to fisheries are not in general circulation and references were largely derived from computer listings provided by Fish and Wildlife Reference Service, Denver, Colorado. Only some are annotated and many are difficult to categorize. We felt that readers might find it useful to have all D-J reports indexed as such. Any that could be readily categorized will appear also in the appropriate section of the index.

In D-J references the following abbreviations are part of the standard computer designation of those reports: PR-progress report, Job-job number assigned that project, wk. pl.—work plan, Fin.-final report, F-6-R-7-a coded number assigned to that report.

10. Distribution and Range-references included here vary from obvious ones to works dealing solely with the total range of the species, to those that include the species in a checklist of a single watershed or region, to some that list the species as present at a single location.

11. Food and Feeding Habits-includes all discussions of food items or feeding activities except those that allude to cannibalism or predator-prey relationships. They are listed under "25. Predator-Prey Relationships".

12. Fossils-records of fossilized remains identified as this species, including "near fossils" from archaeological digs.

13. General Accounts-much like “1. Accounts by Geographical and Political Areas", giving brief comments on several aspects of this fish, but lacking any geographical orientation in the general discussion of this species.

14. Habitat and Environmental Factors-includes not only general descriptions of the habitat of this species but specific environmental requirements, and lethal or sublethal environmental conditions, including analysis for contents of chemicals and other foreign materials dangerous to the fish or its captor.

15. Hybrids-includes references to works that deal with hybrids in nature and those cultured in the laboratory or hatchery.

16. Introduction and Stocking-introduction refers to release into areas beyond the natural range and stocking refers to the re-establishment or support of populations within the natural range by fish cultural practices.

17. Length-Weight Relationships - all compendia of length or weight and comparisons of length and weight, except when they refer strictly to individual fish taken by anglers. Comparisons of length and weight are often associated with " 2 . Age and Growth" but there were so many references to works specifically giving length and weight data that they were indexed separately.

18. Life History and Habits-includes those general discussions of aspects of the biology of the animal in nature that cannot be separately categorized. The category does not include papers on habitat, which are indexed separately. It includes discussions of activities usually referred to in general as habits but not described in ethological terms. The latter are indexed in " 5 . Behaviour".

19. Management (general) - papers that deal with broad subjects allied to the management of muskellunge populations for man's benefit are indexed under this head- 
ing. The category includes papers on production, yield, and catch per unit of effort. There may be some cross-over between this category and "24. Population Studies".

20. Marking and Tagging-regardless of the reason for the mark, studies that make extensive use of marks by mutilation, application, or implantation, whether numbered or electronic, are listed or cross-indexed here.

21. Parasites, Diseases, Pathology - this does not include lethal or sublethal responses to chemicals, other foreign substances, or adverse environmental conditions. These are listed under "14. Habitat and Environmental Factors".

22. Physiology-papers on the internal functions of the body, including response to stress and other environmental factors when results are expressed in terms of physiological processes. For convenience the category includes chemical analysis of parts of the animal in regard to percentage of constituents.

23. Popular Accounts-much like "13. General Accounts" in describing the ani$\mathrm{mal}$ in general terms, but usually in the outdoor magazines, sporting periodicals, or interpretative publications such as conservation publications of state and provincial agencies. Popular articles that deal solely with stories of angling for the muskellunge are indexed under "4. Angling and Record Catches".

24. Population Studies-articles on assessment of population size and factors affecting it, such as survival and natural and fishing mortalities. It is sometimes difficult to separate this category from "19. Management (general)". See also "7. Creel Census".

25. Predator-Prey Relationships-references are included here if the word predation occurs in the title or if it is readily interpreted from the text that the phenomenon of predation on, or predation by, muskellunge was studied. References are set aside in this discrete category as a result of the interest in esocids as predatory control of the numbers of other fishes. Otherwise references to fishes eaten appear in "11. Food and Feeding Habits".

26. Proteins, Enzymes, Electrophoresis-includes discussions of these substances other than in their physiological role. Depending on the application of the results, some of these works apply to "28. Taxonomy, Nomenclature, Systematics".

27. Spawning (natural)-papers that describe spawning in nature, habitat requirements for spawning, and production of young from natural spawning, as opposed to fish culture.

28. Taxonomy, Nomenclature, Systematics-as well as the obvious, this category contains references to adequate taxonomic descriptions of the animal and various means (such as keys) of distinguishing it from others.

The older literature (before 1900) is often confusing as a result of complications arising from the scientific and common names used. In the mid-to-late 1800 s the distinction between the northern pike $E$. lucius and the muskellunge was poorly recognized and some scientific names were used interchangeably. Since descriptions were fragmentary, it is often difficult or even impossible to determine which species was intended, particularly by authors who used the names $E$. estor, E. nobilior, $E$. nobilis, and $E$. lucioides. The scientific names that must be watched for when searching for literature on this species are as follows: 


$\begin{array}{ll}\text { Esox masquinongy } & \text { E. nobilior } \\ \text { E. ohioensis } & \text { E. nobilis } \\ \text { E. immaculatus } & \text { E. atro-maculata } \\ \text { E. masquinongy masquinongy } & \text { E. atromaculata } \\ \text { E. m. ohioensis } & \text { E. amentus } \\ \text { E. m. immaculatus } & \text { Lucius masquinongy } \\ \text { E. lucioides } & \text { L. m. ohioensis } \\ \text { E. estor } & \text { L. m. immaculatus }\end{array}$

The generic name Mascalongus was proposed but little used.

The common names in the literature are even more confusing. Weed (1927) said that the number of its common names is a fairly reliable index of the extent to which a fish attracts public attention. He stated that there were "at least forty legitimate spellings divided into two general groups, those which derive it from Indian words, which have been spelled 'Mas-kinonge' or 'Mas-kenoza', and those which derive it from the French words 'masque-allongé'." He further listed, under headings Esox immaculatus, E. masquinongy, and E. ohioensis, 94 different names applied in different areas. These include the names muskellunge (in its various spellings), pike, pickerel, picareau, tiger, and jack with various modifiers. He included 42 versions that involve various spellings derived from the supposed original French and Indian forms of the name. For further lists of common names given to the muskellunge see also Mellen (1917) and Chambers (1923). The most accepted name at present is muskellunge, but maskinonge and maskinongé are still listed as statute names in Ontario and Quebec.

\section{Acknowledgements}

We had to call on many people in our attempts to verify specific references and also to ascertain whether we had neglected possible sources of literature. Principal among these were C. F. Clark, K. H. Doan, A. W. Eipper, L. D. Johnson, J. H. Klingbiel, V. Legendre, Muskies Incorporated, H. E. Snow, R. A. Sonstegard, B. D. Shupp, J. C. Underhill, H. D. Van Meter, and Janet F. White. To them we extend our thanks for their help. A few people are due special acknowledgement for more extensive help or for making available to us literature lists that they had independently accumulated. They are the staff of the Royal Ontario Museum Library and of the Fish and Wildlife Reference Service, Denver, Colorado, G. B. Beyerle, J. Bondhus, Kathleen L. Hassan, J. J. Hasse, R. Ramsell, and G. G. Selke. To them we would like to extend a special measure of gratitude.

The project was supported in part by Grant A-1705 from the National Research Council of Canada.

The cover illustration was drawn by Peter Buerschaper and the photograph on page 11 was made available by National Fresh Water Fishing Hall of Fame "Record Gallery". The list of large muskellunge on pages 12 and 13 was provided by $L$. Ramsell. 


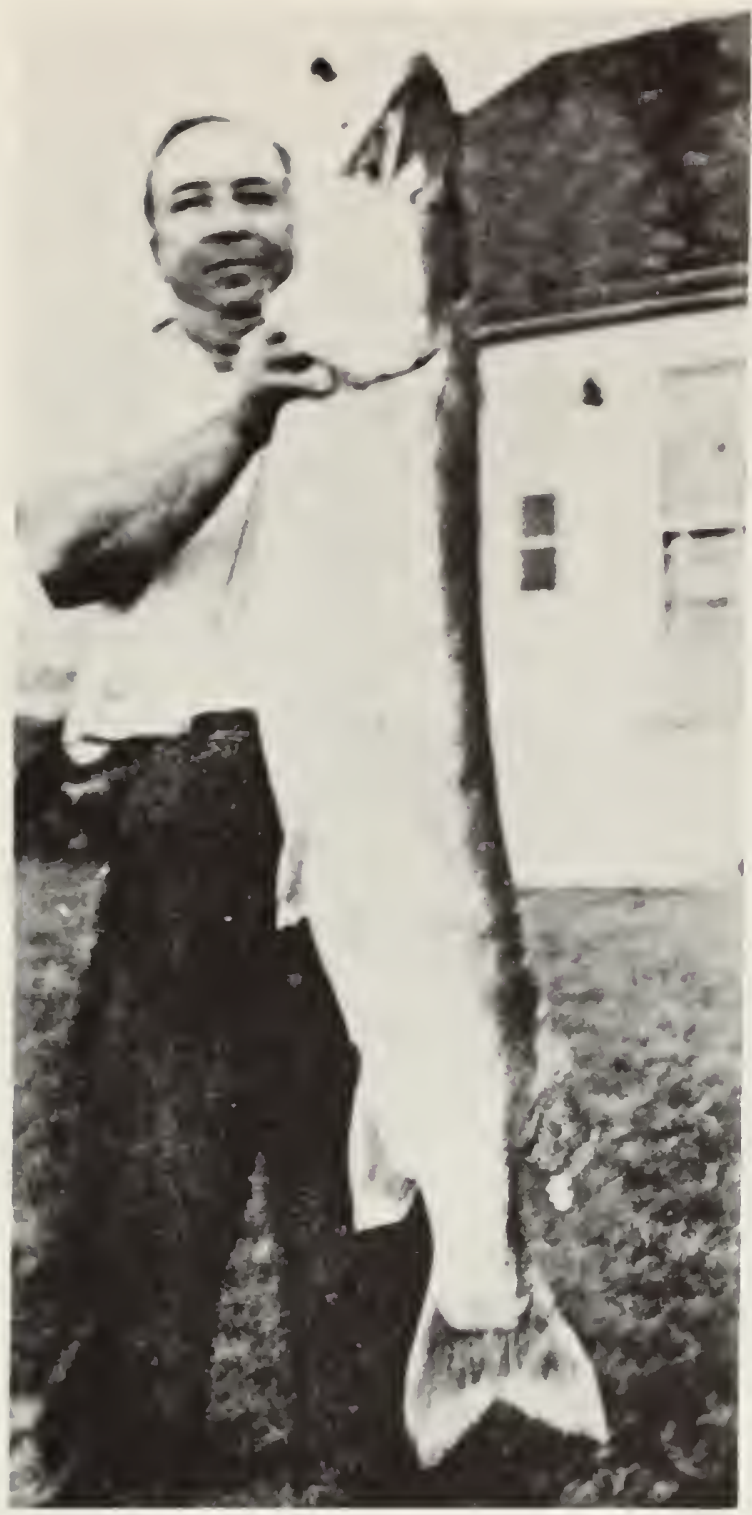

An Lawton holds the accepted world record muskellunge, weight 69 pounds 15 ounces, length $64 \frac{1}{2}$ inches, caught in the St. Lawrence River, New York, in 1957. 
A List of Muskellunge Taken by Anglers Organized in Descending Order by Weight

\begin{tabular}{|c|c|c|c|c|c|}
\hline $\begin{array}{l}\text { Weight } \\
\text { lb-oz }\end{array}$ & $(\mathrm{kg})$ & $\begin{array}{l}\text { Length } \\
\text { in. }\end{array}$ & $(\mathrm{mm})$ & $\begin{array}{l}\text { Girth } \\
\text { in. }\end{array}$ & $(\mathrm{mm})$ \\
\hline $70-4$ & $(31.9)$ & 54 & (1372) & 32 & (813) \\
\hline $69-15^{*}$ & $(31.7)$ & $641 / 2$ & (1638) & $313 / 4$ & (806) \\
\hline $69-11$ & $(31.6)$ & $631 / 2$ & (1613) & $311 / 4$ & (794) \\
\hline $67-8$ & $(30.6)$ & $601 / 4$ & $(1530)$ & $331 / 2$ & (851) \\
\hline $64-8$ & $(29.2)$ & 58 & (1473) & 24 & $(610)$ \\
\hline $62-8$ & $(28.4)$ & $561 / 2$ & (1435) & $321 / 2$ & (826) \\
\hline $58-4$ & (26.4) & 59 & (1499) & $341 / 2$ & (902) \\
\hline $56-8$ & $(25.6)$ & 55 & (1397) & $295 / 8$ & (752) \\
\hline 56.7 & $(25.6)$ & $601 / 2$ & (1537) & 31 & (787) \\
\hline $55-2$ & $(25.0)$ & $501 / 4$ & $(1276)$ & $291 / 2$ & (749) \\
\hline $54-0$ & $(24.5)$ & 57 & (1448) & 25 & (635) \\
\hline $53-8$ & $(24.3)$ & 57 & (1448) & $351 / 4$ & (895) \\
\hline $51 \cdot 1$ & $(23.2)$ & 59 & (1499) & $291 / 2$ & (749) \\
\hline $51-0$ & $(23.1)$ & $563 / 4$ & (1441) & 27 & (686) \\
\hline $51-0$ & $(23.1)$ & 53 & $(1346)$ & $251 / 4$ & (641) \\
\hline $51-0$ & $(23.1)$ & 55 & (1397) & 24 & $(610)$ \\
\hline $48-8$ & $(22.0)$ & $53 \frac{1}{2}$ & (1359) & 25 & (635) \\
\hline $48-0$ & $(21.8)$ & 51 & (1295) & $211 / 2$ & (546) \\
\hline $48-0$ & $(21.8)$ & $52 \frac{1}{2}$ & (1334) & $261 / 2$ & $(673)$ \\
\hline $45-8$ & $(20.7)$ & 55 & (1397) & 24 & $(610)$ \\
\hline $44-12$ & $(20.3)$ & 51 & (1295) & $253 / 4$ & (654) \\
\hline $44-12$ & (20.3) & 52 & (1321) & 28 & (711) \\
\hline $44-3$ & $(20.1)$ & $55^{1 / 4}$ & (1403) & $253 / 4$ & (654) \\
\hline $44-1$ & $(20.0)$ & 53 & (1346) & 26 & $(660)$ \\
\hline $43-0$ & (19.5) & $571 / 2$ & $(1461)$ & 23 & (584) \\
\hline $43-0$ & (19.5) & 54 & (1372) & 23 & (584) \\
\hline $40-3$ & $(18.2)$ & $561 / 2$ & $(1435)$ & $241 / 2$ & $(622)$ \\
\hline $39-11$ & $(18.0)$ & $53 \% / 16$ & $(1367)$ & $223 / 8$ & (568) \\
\hline $39-3$ & $(17.8)$ & $513 / 4$ & (1314) & $22 \frac{1 / 2}{2}$ & (572) \\
\hline $38-5$ & $(17.4)$ & 49 & $(1245)$ & $233 / 4$ & $(603)$ \\
\hline $38-0$ & $(17.2)$ & $521 / 2$ & (1334) & $233 / 4$ & (603) \\
\hline $37-0$ & $(16.8)$ & 49 & $(1245)$ & 25 & (635) \\
\hline 37.0 & $(16.8)$ & 52 & (1321) & 24 & $(610)$ \\
\hline $35-1$ & $(15.9)$ & $491 / 8$ & (1248) & $233 / 8$ & (594) \\
\hline $35-0$ & $(15.9)$ & $501 / 4$ & (1276) & $223 / 4$ & (578) \\
\hline
\end{tabular}

*Accepted world's record. 


\begin{tabular}{|c|c|c|}
\hline 6- $6-54$ & Eau Claire Lake, Wisconsin & Malo \\
\hline $9-22-57$ & St. Lawrence River, New York & Lawton \\
\hline $10-20-49$ & Chippewa Flowage, Wisconsin & Spray \\
\hline $7-24-49$ & LacCourt Oreilles, Wisconsin & Johnson \\
\hline $5-17-47$ & Favil Lake, Wisconsin & Hanser \\
\hline $6-28-40$ & Lake St. Clair, Michigan & Haver \\
\hline 10. $3-39$ & Eagle Lake, Ontario & Coleman \\
\hline$-\quad-31$ & Lake of the Woods, Ontario & Collins \\
\hline $6-13-38$ & Lake St. Clair, Michigan & Haver \\
\hline 4. $\quad-72$ & Piedmont Lake, Ohio & Lykins \\
\hline 8.22 .43 & Lake of the Woods, Ontario & Walshe \\
\hline $8-25-49$ & Lake of the Woods, Ontario & Curtis \\
\hline $5-19-73$ & Leach Lake, Minnesota & Kelner \\
\hline $6-\quad-73$ & Big Round Lake, Wisconsin & Slack, Jr. \\
\hline $9-21-75$ & Flambeau Lake, Wisconsin & Allen \\
\hline $9-13.16$ & Chief Lake, Wisconsin & Swint \\
\hline $10-\quad-61$ & Big Round Lake, Wisconsin & Mense \\
\hline $10-\quad-44$ & Lake of the Woods, Ontario & Unknown \\
\hline $6-20-59$ & Lake "'26", Wisconsin & Schaft \\
\hline $5-26-74$ & Big Winnie, Minnesota & Holsapple \\
\hline $5-29.72$ & Big Round Lake, Wisconsin & Slack, Jr. \\
\hline$-\quad-35$ & Lake of the Woods, Ontario & Walt \\
\hline $6-19-64$ & White Birch Lake, Wisconsin & Schmidt \\
\hline $11 \cdot 4.76$ & Mississippi River, Minnesota & Banks \\
\hline $6-23-75$ & Chippewa Flowage, Wisconsin & Weller \\
\hline $9-25-76$ & Rainy Lake, Ontario & Rose \\
\hline $9-22.76$ & Leech Lake, Minnesota & Cotton \\
\hline \multirow[t]{2}{*}{$8-5-73$} & Chippewa Flowage, Wisconsin & LeMay \\
\hline & Long Interlocken, Wisconsin & Anderson \\
\hline $10-\quad-72$ & Chippewa Flowage, Wisconsin & Schmidt \\
\hline $9-12-75$ & Lake Okeboji, Iowa & Feldhacker \\
\hline \multirow[t]{2}{*}{$11--73$} & Buckatoban, Wisconsin & Hoeft \\
\hline & Squaw Lake, Wisconsin & Weinfurtener \\
\hline $6-18-14$ & Lac Vieux Desert, Wisconsin & Elsworth \\
\hline 8.9 .76 & Lake of the Woods, Ontario & Stoner \\
\hline
\end{tabular}




\section{Annotated Bibliography}

Anon. no date a

Fishes of Ohio. Egg counts of ovaries of ripe females. 3 pp. Mimeograph.

One eight-pound muskellunge contained 30,000 eggs.

Anon. no date b

Maskinonge studies. R. Ontario Mus. Zool. 2 pp. Mimeograph.

Describes three so-called subspecies of muskellunge. What was called the true tiger muskellunge is given the scientific name Esox amentus.

Anon. 1854

No title. Proc. Boston Soc. Nat. Hist. (1851-1854) 4: 287.

An attempt to introduce the muskellunge (Esox nobilior) into a pond at Cape Cod, Massachusetts, failed when the water they were transported in was changed and the fish died.

Anon. 1877

Pike, pickerel and maskalonge. For. Stream 8(20): 320.

Distinguishing features and description of the muskellunge.

Anon. (O. O. S.) 1888

Maskinonge at Bear Lake. For. Stream, July.

Anon. 1896 a

Report of the Superintendent of Hatcheries. New York Commrs. Fish. Ist Annu. Rep.: 62-99.

Contains a brief note on the Chautauqua Lake muskellunge culture programme.

Anon. 1896 b

Commercial fisheries of the interior waters of the state. New York Commrs. Fish. 1st Annu. Rep.: 118-120.

Quantity and yield of commercial fishing for muskellunge in New York, 1894 and 1895.

Anon. (E. M.) 1897 a

La ville de Racine. Bull. Recherches Historiques 3(3): 41-42.

Historical account of the naming of a town in Wisconsin. Muscallonge was suggested because of the great numbers of the fish present in the river on which the town was situated.

Anon. 1897 b

Distribution of fish. Schedule of waters stocked for the year ending September 30, 1896. New York Commrs. Fish. Game For. 2nd Annu. Rep.: 145-175.

Information, by species, on distribution of fish stocked in 1896 .

Anon. 1898

Distribution of fish. Schedule of waters stocked for year ending September 30, 1897. New

York Commrs. Fish. Game For. 3rd Annu. Rep.: 147-190.

Information, by species, on distribution of fish stocked in 1897.

Anon. 1899

Distribution of fish. Schedule of waters stocked for the fiscal year ending September 30, 1898.

New York Commrs. Fish. Game For. 4th Annu. Rep.: 127-174.

Information, by species, on distribution of fish stocked in 1898 .

Anon. 1900 a

Distribution of fish from each hatchery. New York Commrs. Fish. Game For. 5th Annu. Rep. (1899): 77-80.

Distribution of muskellunge from Chautauqua Lake hatchery in 1899. 
Anon. $1900 \mathrm{~b}$

Total summary of fish planted. New York Commrs. Fish. Game For. 5th Annu. Rep. (1899): $80-81$.

Total numbers of muskellunge planted in 1898 and 1899 are compared.

Anon. $1900 \mathrm{c}$

Total summary of fish planted from September 30, 1898 to September 30, 1899. New York

Commirs. Fish. Game For. 5th Annu. Rep. (1899): 186-187.

Summarizes numbers of muskellunge stocked in 1898 and 1899

Anon. $1900 \mathrm{~d}$

Distribution of fish. Schedule of waters stocked for the fiscal year ending September 30, 1899.

New York Commrs. Fish. Game For. 5th Annu. Rep. (1899): 119-185.

Distribution of fish stocked in 1899.

Anon. 1901

Fish distribution. Summary for the year ending September 30, 1900. New York For. Fish Game Comm. 6th Annu. Rep. (1900): 56.

Summarizes the numbers of muskellunge that were distributed from the hatchery in 1900 .

Anon. 1902 a

Fish distribution. Summary for the year ending September 30, 1901. New York For. Fish Game Comm. 7th Annu. Rep. (1901): 62.

Summarizes the numbers of muskellunge that were planted that year.

Anon. 1902 b

Pike, pickerel, mascalonge. For. Stream 59(3): 50-51.

Description, range and potential size of the muskellunge given. For pike, chain pickerel, and muskellunge, there is a drawing of the whole body and an enlarged one of the head. Some of the figure captions are in error (see Evermann, 1902).

Anon. $1902 \mathrm{c}$

Pike, pickerel, mascalonge. For. Stream 59(4): 71.

The captions for the illustrations that appeared in an earlier article (Anon. 1902 b) are revised. A short description of the muskellunge is given.

Anon. 1904

Fish distribution. Summary for year ending September 30, 1903. New York For. Fish Game Comm. 8th, 9th Annu. Reps. (1902, 1903): 150-153.

Number of muskellunge planted.

Anon. 1907 a

Hatchery repairs and improvements. Report of the state Fish Culturist for the year 1906. New York For. Fish Game Commr. 10th, 11th, 12th Annu. Reps. (1904, 1905, 1906): 177-192.

Note on the Chautauqua Lake Hatchery, including numbers of each species raised to fry.

Anon. 1907 b

Pickerel fishing in the lakes - muscallonge - field work - pickerel work. Pennsylvania Dep. Fish. Rep. (Dec. 1, 1905 to Nov. 30, 1906): 21-22, 23-28, 51-55, 140-141.

Anon. 1925

Tables of game fish raised and distributed in Ontario and the United States. Toronto Anglers Assoc. Conserv. Committee. 1 p. Mimeograph.

Gives the number of muskellunge raised and distributed in New York and Pennsylvania. 
Anon. 1928

The game fishes of Canada. Canadian Pacific Railway Publ. 45 pp.

Describes the muskellunge, its Canadian distribution, size, life history, habits, and distinguishing features.

Anon. 1938

A tangle of letters gives Steve some light on modern fish management. Ohio Conserv. Bull., September: $1-8$.

Briefly mentions the muskellunge.

Anon. 1940 a

Hatchery production of maskinonge. Ontario Dep. Game Fish. Monthly Bull., March-April: 9-10.

Fingerling muskellunge were reared in a pond at the Deer Lake Hatchery, Ontario, to determine if it was practical to raise them artifically.

Anon. 1940 b

A fine record. Ontario Dep. Game Fish. Monthly Bul1., March-April: 10-12.

Report of a record-size muskellunge.

Anon. MS 1941

The Chautauqua Lake muskalonge problem. New York Dep. Environ. Conserv. Rep. 8 pp. Manuscript.

Anon. 1942

No title. New York Conserv. Dep. 31st Annu. Rep. (1941), Legis. Doc. 32. 402 pp.

Anon. 1946 a

No title. New York Conserv. Dep. 34th, 35th Annu. Reps. (1944, 1945), Legis. Doc. 61. 322 pp.

Anon. 1946 b

Pike, pickerel and maskinonge. R. Ontario Mus. Zool. Cir. 1. 3 pp. Mimeograph.

Discussion of the use of the names pike, pickerel, and maskinonge and of the species to which each refers.

Anon. 1948

Chautauqua Lake. Jamestown, New York, Chamber Commerce. 24 pp.

Anon. 1949

A preliminary report on the fish and wildlife resources in relation to the water development plan for Chautauqua Lake and the Chadakoin River, New York. U.S. Fish Wildl. Serv. River Basin Stud. 9 pp.

Anon. 1952 a

No title. New York Conserv. Dep. 41st Annu. Rep. (1951), Legis. Doc. 49: 134-135.

Anon. 1952 b

Monkeying with nature. Northern Sportsman 7(4): 14-15, 27.

Anon. 1953

No title. New York Conserv. Dep. 42nd Annu. Rep. (1952), Legis. Doc. 27: 131-133.

Anon. 1954

No title. New York Conserv. Dep. 43rd Annu. Rep. (1953), Legis. Doc. 47: 139-141. 
Anon. 1955

Musky fishermen of 1901 spoke of "Good old days". Wisconsin Conserv. Bull. 20(4): 17.

Discusses the possibility that size and number of muskellunge caught by anglers had decreased because of overfishing.

Anon. 1956

Three suffer muskie bites while dunking their feet. For. Outdoors, September.

Anon. 1957

Advice to State that's new to musky fishing. Wisconsin Conserv. Bull. 22(2): 30 .

Briefly discusses angling for muskellunge.

Anon. 1958

Area watershed stabilization management project. Wisconsin Conserv. Dep., D-J Proj. F-1-D-8. 71 pp.

Anon. 1959

Paradis du pêcheur la province de Québec. Quebec fisherman’s paradise. Québec Tourist Bur.

Brochure. 4 pp. [In French and English.]

Distribution map for Quebec and colour drawing.

Anon. 1960 a

Capture et baguage de maskinongés au lac Donaldson. Québec Minist. Chasse Pêch. J. Bord 3(54): 419-421.

For muskellunge captured, data are given on weight, size, and temperature of water at time of capture.

Anon. $1960 \mathrm{~b}$

Pisciculture de Lachine: rapport sur la capture et la ponte des maskinongés, année 1960.

Québec Minist. Chasse Pèch. J. Bord 3(58): 467-470.

Plan and positioning of the traps used.

Anon. 1961

Contribution de la Station Piscicole de Lachine à l'étude du maskinongé. Québec Minist. Chasse Pêch. J. Bord Suppl. 3(1): 1-55.

Various notes and articles, by several authors, on the muskellunge, primarily on culture and associated work.

Anon. 1964 a

Muskellunge the master of ambush-style attack. Inland Game Fishing Pro-amateur Sports Library Book 2.

General descriptive note of interest to the angler.

Anon. 1964 b

Two large muskies taken by netting crews. Iowa Conserv. 23(5): 40.

Anon. 1965

Game fish and fishing in Algonquin Provincial Park. Ontario Dep. Lands For. Mus. Bull. 2. 30 pp.

Checklist incudes Esox masquinongy.

Anon. 1966 a

Fish and wildlife as related to water quality of the Lake Michigan Basin. A special report on fish and wildlife resources. U.S. Dep. Inter. Bur. Sport Fish. Wildl. Bur. Commer. Fish.

Suggests that muskellunge are eliminated by poor water quality. 
Anon. 1966 b

L’élevage du maskinongé exige beaucoup de précautions. Breeding muskellunge requires many precautions. Québec Dep. Tourisme Chasse Pêch. Bull. 1(12): 30-31. [In French and English.]

Partial explanation of difficulties in maintaining hatchery fish and efforts to overcome some of the problems.

Anon. 1967 a

Forty-pounders netted in Lake St. Lawrence. Ontario Dep. Lands For. Newslett. 20(31): 4-5.

Anon. 1967 b

Muskellunge culture and management workshop. Higgins Lake, Michigan, Proc. Muskellunge Workshop, September 17-18.6 pp. Mimeograph.

Anon. 1969

Esocid culture workshop. Put-in-Bay, Ohio, Proc. Interstate Muskellunge Workshop, September 24-25. 39 pp. Mimeograph.

Anon. 1970 a

No title. Higgins Lake, Michigan, Proc. 3rd Annu. Interstate Muskellunge Workshop, September 28-30. 25 pp. Mimeograph.

Anon. 1970 b

Muskellunge program. Minnesota Dep. Nat. Resour. Sect. Fish.

Anon. $1970 \mathrm{c}$

37 tons of muskies. Sport Fish. Inst. Bull. 212: 4.

Discusses angling for muskellunge in Chautauqua Lake, New York.

Anon. 1971 a

No title. Eagle River, Wisconsin, Proc. 4th Annu. Interstate Muskellunge Workshop, September 13-15. 33 pp. Mimeograph.

Anon. (Staff) $1971 \mathrm{~b}$

Muskalonge, maskinonge, mascalongé, muskellunge or muskie: they all spell fighter. True, October: 86-91.

Anon. $1971 \mathrm{c}$

Muskies. Ontario Fisherman Hunter 3(9).

Anon. 1972

Musky workshop, Chautauqua Lake, 1972. New York Dep. Environ. Conserv. 7 pp. Mimeograph.

Anon. 1973

Wisconsin muskellunge waters. Wisconsin Dep. Nat. Resour. Publ. 1-3600(73). 25 pp.

Anon. 1974 a

Musky production in Kentucky hatchery using various musky fry stocking rates and adding fathead minnows as supplemental forage. Morehead, Kentucky, Proc. 6th Interstate Muskellunge Workshop, September 25-26: 31-33. Mimeograph.

Problems of rearing muskellunge and muskellunge forage are discussed briefly. Data collected on muskellunge reared in ponds are presented in a table.

Anon. 1974 b

Muskellunge fry production by pond spawning at the Minor E. Clark Hatchery, Kentucky. Morehead, Kentucky, Proc. 6th Interstate Muskellunge Workshop, September 25-26: 61-63. Mimeograph. 
Describes method of muskellunge pond spawning in Kentucky. Data on number of fry and fingerlings produced are given.

Anon. $1974 \mathrm{c}$

Program for development of muskellunge fishing. Minnesota Dep. Conserv. Div. Game Fish. Sect. Fish.

Anon. $1974 \mathrm{~d}$

Woodruff hatchery. Wisconsin Dep. Nat. Resour.

Anon. 1975

Wisconsin Lakes. Wisconsin Dep. Nat. Resour. Publ. 7-3600(75). 79 pp.

Ackerman, B. 1955

Handbook of fishes of the Atlantic Seaboard. Washington, D.C., American Printing. 144 pp.

Brief description of the muskellunge includes notes on growth, coloration, subspecies, plantings, habitat, habits, and angling notes. Accompanied by a small colour drawing. (pp. 112-114)

Aflalo, F. G. 1911

A fisherman's summer in Canada. Toronto, McClelland and Goodchild. $147 \mathrm{pp}$.

An angler's reminiscence of his trip through part of Canada. Briefly describes angling for muskellunge, including type of lure used, method of trolling, and size of fish.

Agassiz, L. 1850

Lake Superior: its physical character, vegetation, and animals, compared with those of other and similar regions. Boston, Gould, Kendall and Lincoln. $428 \mathrm{pp}$.

Esox estor as described by Richardson is suggested to be not the true Esox estor Lesueur (= muskellunge) nor the Esox boreus (= pike) of Agassiz from Lake Superior but some other distinct species according to the small size of its scales. (p. 317)

Allen, J. L., C. W. Luhning and P. D. Harman 1972

Residues of MS-222 in northern pike, muskellunge and walleye. U.S. Fish Wildl. Serv., Invest. Fish Control 45: 3-8.

Residues of MS-222 (tricaine methanesulfonate) in muscle tissue of northern pike, muskellunge, and walleye following anaesthesia were measured by a modified Bratton-Marshall colorimetric method and confirmed by thin-layer chromatography. The residues dissipate rapidly from the muscle when fish are withdrawn from the anaesthetic and are near the background readings of the controls within 24 hours. (Authors' abstract)

Anderson, D. J. 1965

Water wolves. Field Stream, June: 40-42, 149-154.

Anderson, L. A. 1963

How to catch a musky. Fur-Fish-Game, August: 14-15, 41 .

Anderson, L. A. 1966

Red hot muskies of the Manitowish. Fur-Fish-Game, February: 19-23.

Anderson, L. A. 1968

l'll take muskies - if I can. Fur-Fish-Game, September: 10-11, 21-22.

Anderson, L. A. 1971

Muskies in the weeds. Fur-Fish-Game, August: 8-9, 42-43.

Anderson, L. A. 1973

Where and how to catch a musky. Fur-Fish-Game, July: 6-7, 31. 
Anderson, L. R. 1948

Unusual items in the diet of the northern muskellunge (Esox masquinongy immaculatus). Copeia 1948(1): 63 .

The stomach contents of a 50.5 inch $(1.28 \mathrm{~m}), 43.5$ pound $(19.7 \mathrm{~kg})$ muskellunge were examined. A muskrat (Ondata z. zibethica) and a pied-billed grebe (Podilymbus p. podiceps) were found.

Other incidences of unusual stomach contents are mentioned.

Andrews, H. 1969

New York muskies. Fur-Fish-Game, May: 3-5.

Annin, J., Jr. 1896

Report of the Superintendent of hatcheries. New York Commrs. Fish. Game For. 1st Annu. Rep.: 62-75.

Muskellunge said to be native in very few New York State lakes. Suggests liberal planting in Chautauqua Lake and the St. Lawrence River.

Annin, J., Jr. 1897

Report of the Superintendent of hatcheries. New York Commrs. Fish. Game For. 2nd Annu. Rep.: 112-120.

At the time, all muskellunge culture was done in Chautauqua Lake in double-wire screen boxes.

Annin, J., Jr. 1898

Report of the Superintendent of hatcheries. New York. Commrs. Fish. Game For. 3rd Annu. Rep.: 126-136.

Describes method used to propagate muskellunge in wired boxes, and care taken when approving applications for the planting of fry. Includes hatchery fish distribution records.

Annin, J., Jr. 1899

Report of the Superintendent of State hatcheries. New York Commrs. Fish. Game For. 4th Annu. Rep.: 113-122.

Hatching eggs had been done in boxes with double-wire screen tops and bottoms, submerged in the water. However, glass jars were tried with some success.

Chautauqua Lake considered best muskellunge water in the state. Tables showing distribution of fishes from the hatcheries are included.

Apgear, D. B. 1966

Fish inventory and evaluation. Pike Lake Progress Report. Ohio Div. Wildl., D-J Proj. F-29-R-5, Job 7, PT5: 206-238.

Apgear, D. B. 1967

Pike Lake progress report. Ohio Dep. Nat. Resour. Div. Wildl. 31 pp.

Muskellunge stocked in Pike Lake appeared to be doing well but were removed as they were thought detrimental to bass, bluegill, and crappie populations.

Armbruster, D. 1966

Hybridization of the chain pickerel and northern pike. Prog. Fish-Cult. 28(2): 76-78.

Hybrids of chain pickerel and northern pike were produced and their growth compared with northern pike, chain pickerel, and muskellunge. Muskellunge held in rearing troughs suffered extreme losses when water temperature exceeded $70^{\circ} \mathrm{F}\left(21^{\circ} \mathrm{C}\right)$, owing to bacterial gill disease.

Armstrong, A. 1969

Lake Wisconsin. An underwater world at the Milwaukee Zoo. Anim. Kingdom 72(1): 2-9. 
Armstrong, A. E. MS 1963

Tagging and transfer of maskinonge from Maskinonge Lake and Little Vermilion Lake in Sioux Lookout District, 1963. Ontario Dep. Lands For. 12 pp. Manuscript.

A tagging and transfer progranme was carried out on Maskinonge Lake, Ontario, in 1963. Of 140 fish captured, 136 were transferred to Little and Minnitaki lakes. Age comparisons indicated that the growth rate was slower than in more southerly lakes.

Armistrong. G. C. 1967

An historical review of the management of the sport fishery in Ontario. Ontario Fish Wildl. Rev. 6(1-2): 25-34.

Black and white photograph of Mr. W. Spreadborough and a muskellunge he captured.

Armstrong. J. O. 1904

Maskinongé or maskenozha. For. Stream 62(15): 298.

Atwater, W. O. 1885

Contributions to the knowledge of chemical composition and nutritive values of American food-fishes and invertebrates. U.S. Comm. Fish Fish. Commr. Rep. (1883) 15: 433-499 $(1-67)$.

Detailed analysis of chemical composition and nutritive values as calculated from various chemical experiments.

Ayles, H. 1970

Common parasites of Ontario fishes with key to identification. Ontario Dep. Lands For. Fish Wildl. Branch, Fish Inventory Unit. $21 \mathrm{pp}$.

For each parasite there is a list of fish species that it infects.

Ayres, W. O. 1854

No title. Proc. Boston Soc. Nat. Hist. (1851-1854) 4: 288

Fifteen years earlier, the muskellunge (Esox nobilior) was introduced into a pond near Bellows Falls. When an embankment broke through, the fish escaped into the Connecticut River and became established.

Bachop, W. E. MS 1958

Studies on the developmental anatomy of Esox masquinongy ohioensis Kirtland. Ohio State Univ., M.Sc. thesis. 160 pp.

Comprehensive study of muskellunge embryology. Contains a historical review of the literature on fish embryology, particularly on the pike. Method of fixing and staining embryos after various stages of development is discussed in detail. The following stages and areas of development are discussed: segmentation of the germinal disc, descriptions of embryos on the yolk, integumentary system, excretory system, muscular system, and skeletal system.

Bachop, W. E. MS 1963

Feulgen microphotometry of periblast nuclei in the muskellunge embryo (Clupeiformes: Esocidae). Ohio State Univ., Ph.D. thesis. 309 pp.

DNA contents of periblast nuclei and non-periblast nuclei from muskellunge embryos were measured by two-wave length feulgen microphotometry and compared. Morphology of periblast nuclei in situ was observed and photographed.

Bachop, W. E. 1964

Periblast nuclei in situ on yolk of unsectioned muskellunge embryos as visualized by sequence of aldehyde blockade, feulgen processing and immersion in oil (Clupeiformes: Esocidae). Proc. Nebraska Acad. Sci. 74.

Bachop, W. E. 1965

Size, shape, number, and distribution of periblast nuclei in the muskellunge embryo (Clupeiformes: Esocidae). Trans. Am. Microsc. Soc. 84(1): 80-86. 
Observations of whole nuclei in fixed unsectioned periblast in situ on the yolk. Photomicrographs were used as an intermediate stage in mapping periblast nuclei.

Distribution, number, size, and shape of the periblast nuclei after 238,163 , and 95 hours of incubation, were studied from the "maps".

Bachop, W. E. 1966

Heuristic concepts of periblast nuclei of teleost embryos. J. Cell Biol. 31: 7A.

Bachop, W. E. 1967

Feulgen-positive configurations within giant nuclei of unsectioned periblast in situ on yolk of muskellunge embryos (Clupeiformes: Esocidae). Trans. Am. Microsc. Soc. 86(1): 71-72.

Bachop, W. E. 1968

An operational definition of the term "periblast" for the muskellunge embryo (Clupeiformes: Esocidae). Trans. Am. Microsc. Soc. 87(1): 120.

In the muskellunge there is only one acellular protoplasmic layer appressed to the yolk surface. This is designated as the periblast. Gives a description of this layer.

Bachop, W. E. and E. J. Harris 1971

Topographic and microscopic anatomy of the yolk sac of oviparous teleosts: disparity between textbooks and scientific joumals. South Carolina Acad. Sci. Bull. 33: 83.

Bachop, W. E. and J. W. Price 1969

Nuclear crowding, overlapping spindles, and nuclear coalescence: antecedents of giant nuclei in the periblast of a teleost embryo (Clupeiformes: Esocidae). Trans. Am. Microsc. Soc. 88(1): 168.

Bachop, W. E. and J. W. Price 1971

Giant nuclei formation in the yolk sac syncytium of the muskellunge, a bony fish (Salmoniformes: Esocidae: Esox masquinongy). J. Morph. 135(2): 239-246.

Continued synchronous mitosis of neighbouring syncytial nuclei and crowding together of spindles culminate in overlapping spindles, multipolar spindles, disorganized spindles, and the crowding of numbers of chromosomes from contiguous spindles. When condensed chromosomes become enclosed within one nuclear membrane, a giant nucleus appears in the following interphase.

\section{Bachop, W. E. and F. J. Schwartz 1974}

Quantitative nucleic acid histochemistry of the yolk sac syncytium of oviparous teleosts: implications for hypotheses of yolk utilization. pp. 345-353. In Blaxter, J. H. S., ed. The early life history of fish. Berlin, Springer-Verlag.

DNA contents of individual nuclei in an embryo were compared by feulgen microphotometry. The yolk-sac syncytium of each embryo contained giant nuclei whose DNA contents were four or more times those of nuclei within diploid cells of the same embryo.

Bailey, R. M. 1951

A checklist of the fishes of Iowa with keys for identification. lowa Conserv. Comm. [Reprinted from lowa Fish Fish.] 238 pp.

Checklist and key gives Esox masquinongy immacularus (pp. 189-211).

Bailey, R. M. 1956

A revised list of the fishes of lowa, with keys for identification. pp. 325-377. In Harlan, J. R. and E. B. Speaker. lowa fish and fishing. 3rd ed. lowa Conserv. Comm. 377 pp.

Believes it is unnecessary to recognize subspecies of the muskellunge. Key to families and key to species are given.

Bailey, R. M., J. E. Fitch, E. S. Herald, E. A. Lachner, C. C. Lindsey, C. R. Robins and W. B. Scott 1970 
A list of common and scientific names of fishes from the United States and Canada. 3rd ed. Am. Fish. Soc. Spec. Publ. 6. 150 pp.

Standard for accepted common and scientific names.

Baker, W. D. 1966

Fish management research. Power reservoir investigations. Biology of Fontana Reservoir fishes. Determination of fishing pressure and fishing success, Fontana Reservoir. North Carolina Wildl. Resour. Comm., D-J Proj. F-16-R-2, wk. pl. 3, Job A. Job B. 75 pp.

Balcerzak, R. 1971

Catch muskies deep - on structure! Fish. Facts, July: 15-20.

Balcerzak, R. 1972

Fall is big musky time. Fish. Facts, October: $43-48$.

Balcerzak, R. 1973 a

Never take the fish for granted. Fish. Facts, June: 93-95.

Balcerzak, R. 1973 b

How to pick a good lake for musky. Fish. Facts, July: 67-74.

Ball, M. 1954

Masters of the monster musky. Field Stream, June: 12.

Bangham, R. V. 1944

Parasites of northem Wisconsin fish. Trans. Wisconsin Acad. Sci. Arts Lett. 36: 291-325.

Bangham, R. V. 1955

Studies on fish parasites of Lake Huron and Manitoulin Island. Am. Midl. Nat. 53(1): 184 194.

Lists parasites found on the one muskellunge examined.

Bashline, J. 1971

Minnesota for muskies. Field Stream, April: 78-79, 230-231.

Bashline, J. 1973 a

In search of the muskie. New Guide to Freshwater Fishing, Field Stream: 40-42, 45.

Bashline, J. 1973 b

Pennsylvania's muskellunge population runneth over. Fish. World, May/June: 40-41, 56, 58-59.

Baskett, J. N. 1899

The story of the fishes. Appletons' Home Reading Books, New York, D. Appleton. 297 pp. Muskellunge briefly mentioned. (p. 265)

Bauer, E. A. 1951 a

Muskies in Ohio. Part 2. Ohio Conserv. Bull. 15(13): 21.

Bauer, E. A. 1951 b

The Ohio muskellunge. Ohio Conserv. Bull. 15(6): 1 .

Bauer, E. A. 1957 a

Muskies by the millions. Sports Afield Fish. Annu.: 56-58, 60-61.

Bauer, E. A. 1957 b

Wisconsin's musky country. Fisherman, October: 25-28, 52, 59, 63. 
Bauer, E. A. 1959

Chippewa Country. Sports Afield, May: 67-71, 102-103.

Bauer, E. A. 1961

Best musky lake in America. Sports Afield, June: 40-43, 91-92.

Bauer, E. A. 1963 a

Five days for muskies. Outdoor Life 131(4): 76-79, 94-96.

Bauer, E. A. 1963 b

The Chippewa. Sports Afield, April: 25-29, 114-116.

Bauer, E. A. 1963 c

A case of muskellunge madness. Sports Afield, October: 23-25, 96-97.

Bauer, E. A. 1965

Muskie explosion. Outdoor Life 135(3): 20-23, 71-74.

Bauer, E. A. 1967

This tiger takes a lot of killing. True's Fish. Yearbook: 26-29, 77-78.

Bauer, E. A. 1970

Mid-west muskies. Garcia Fish. Annu.: 79-82.

Bauer, E. A. 1971

Fall muskies are a happy madness. Sports Afield, September: 52-53, 112-114.

Bauer, E. A. 1973

Tracking a tiger. Cord Sportfacts Fish. Rep.: 18-22, 78, 79.

Bauer, E. A. and P. Bauer 1970

Tricks for muskies. Fur-Fish-Game, April: 16-18.

Bauer, P. 1964

Try muskie angling. Fur-Fish-Game, August: 28-29.

Baysinger, B. 1969

Hotspot for Missouri muskie. Fish. Hunting Guide, September: 34.

Beamish, R. J., M. J. Merrilees and E. J. Crossman 1971

Karyotypes and DNA values for members of the suborder Esocoidei (Osteichthyes: Salmoniformes). Chromosoma 34: 436-447.

Summary of chromosome counts; relative and absolute amounts of DNA/mg/cell for the Esocoidei including Esox masquinongy. Includes a figure showing squash preparation of gill tissue.

Bean, T. H. 1881

Check-list of duplicates of North American fishes distributed by the Smithsonian Institution in behalf of the United States National Museum. Proc. U.S. Natl. Mus. (1880) 3: 75-116.

Gives catalogue numbers of specimens of Esox nobilior Thompson that were sent to Sandusky, Ohio. (p. 104)

Bean, T. H. 1891

The pike family - 111. For. Stream, May: 14 
Bean, T. H. 1897

Notes upon New York fishes received at the New York Aquarium, 1895-1897. New York Commrs. Fish. Gane For. 2nd Annu. Rep.: 207-247.

Measurenents and meristic counts given for three specimens of muskellunge, Lucius masquinong.' immucularus. Also noted: description, habitat, and fish-culture operations.

Bean, T. H. 1899

The mascalonge. For. Stream, May: 6, 13.

Bean, T. H. 1902

Food and game fishes of New York. New York For. Fish Game Comm. 7th Annu. Rep. (1901): $251-460$.

Considers three species of muskellunge, for which details are provided as follows: (1) Lucius musquinongy (spotted mascalonge), synonymy, description, distribution, capture records, habits, angling, colour drawing; (2) Lucius immaculatus (northern mascalonge), description and distribution; (3) Lucius ohiensis (unspotted, barred), description of specinens, and fish culture in Chautauqua Lake.

Bean, T. H. 1903

Catalogue of the tishes of New York. New York Univ. Bull. 278, New York State Mus. Zool. 9 Bull. 60.784 pp.

Considers Mascalongus as a sub-genus of one species Lucius masquinongy (spotted musky) and one subspecies Lucius masquinongy immaculatus (unspotted, barred).

The following information is given for L. masquinongy: synonymy, detailed description, occurrence, record catches, and habits, including a curious account of feeding on " gelatinous green balls" (Coelenterata?).

For $L$. masquinongy immaculatus information on synonymy, detailed description, measurements. (pp. 301-307)

Bean, T. H. 1907

Notes upon certain fishes of New York. New York For. Fish Game Commr. 10th, 11 th, 12 th Annu. Reps. (1904, 1905, 1906): 192-231.

Notes on culture of muskellunge in Chautauqua Lake, New York.

Bean, T. H. 1908

The muskalonge of the Ohio Basin. Trans. Am. Fish. Soc. 37: 145-151.

Discusses problems encountered in artificial propagation of the muskellunge and relates attempts to hatch eggs. Includes a description of the Ohio muskellunge and notes on life history and angling.

Bean, T. H. 1910

Notes on New York fishes. pp. 339-357. In Bean, T. H. Report of the state Fish Culturist. New York For. Fish Game Commr. 13th, 14th, 15th Annu. Reps. (1907, 1908, 1909): 308-357.

Attempts to explain loss of muskellunge eggs in Chautauqua Lake Hatchery, New York.

Becker, G. C. 1964 a

The fishes of Pewaukee Lake. Trans. Wisconsin Acad. Sci. Arts Lett. 53: 19-27.

Muskellunge were planted in Pewaukee Lake, Wisconsin, in 1937, 1939, and 1940. Discusses two reported catches of muskellunge and comments on authenticity.

Becker, G. C. 1964 b

The fishes of Lakes Poygan and Winnebago. Trans. Wisconsin Acad. Sci. Arts Lett. 53: 29-52.

Lake Winnebago contained a small population of muskellunge but none was reported from Lake Poygan, Wisconsin. 
Becker, G. C. 1966

Fishes of southwestern Wisconsin. Trans. Wisconsin Acad. Sci. Arts Lett. 55: 87-117.

Muskellunge were considered to be rare in southwestern Wisconsin. Angler catch reports discussed.

Becker, G. C. 1972

Annotated list of the fishes of the Pine-Popple Basin. Trans. Wisconsin Acad. Sci. Arts Lett. 60: 309-329.

Esox masquinongy said to be present in the Pine-Popple Basin area, Wisconsin.

Becker, R. H. 1921

"Chip" River muskies. Field Stream, August: 386-388.

Bell, B. E. 1928

The tiger of the lakes. For. Stream, January: 10-11.

Bennett, G. W. 1962

Management of artificial lakes and ponds. New York, Reinhold. 283 pp.

Bennington, J. C. 1959

Fishing in the year 2000. Sports Afield, October: 71-73, 119.

Bensley, B. A. 1915

The fishes of Georgian Bay. pp. 1-52. In Contributions to Canadian biology being studied from the biological stations of Canada 1911-1914. Fasciculus 11 - Fresh water fish and lake biology. Canada Dep. Mar. Fish. Suppl. 47th Annu. Rep. Sessional Pap. 39b. 221 pp.

Descriptive note on Lucius masquinongy and key.

Berg. L. S. 1936

The suborder Esocoidei (Pisces). Bull. Inst. Rech. Biol. Perm. 10: 385-391. [In Russian, English summary.]

Says there are mistakes in the description of the skull of Esox masquinongy as given by Gregory (1933).

Bergh, K. 1969

How to catch a muskie. Sports Recreation, September/October: 6-7.

Bergh, K. 1973

The muskie mystique. Sports Recreation, March/April: 10-11.

Bergman, R, 1958

Unruly Esox family. Outdoor Life 122(3): 120-123.

Bernard, C. 1964

Maskinongés capturés en 1963 dans la rivière Chaudière, et enregistrés auprès des associations de pêche de la Beauce. Québec Minist. Tourisme Chasse Pêch. Serv. Faune Rapp. 3: 423-432.

Catch records are given, including frequency of catch of weight groups and a plot of length against weight.

Bernard, C. 1967

Le pêche sportive au maskinongé dans la rivière Chaudière, comté de Beauce, et dans le Saint-Augustin, comté de Portneuf, 1964. Québec Minist. Tourisme Chasse Pêch. Serv. Faune Rapp. 4: 297-305.

Follow-up report giving catch records.

Best, E. 1971

New world's record fish coming up? Fish. Facts, July: 21-23. 
Beyerle, G. B. 1971

Warmwater fish biology and population ecology. Food habits of predatory fish in lakes. Michigan Dep. Conserv., D-J Proj. F-29-R-5, wk. pl. 1, Job 1. 10 pp.

Beyerle, G. B. 1973

Warmwater fish biology and population ecology. Comparative growth, survival, and vulnerability to angling of northern pike, muskellunge and the hybrid tiger muskellunge stocked in a small lake. Michigan Dep. Nat. Resour., D-J Proj. F-29-R-7. 11 pp.

Bishop, R. D. 1965 a

Muskellunge investigations. Muskellunge culture techniques. Tennessee Game Fish Comm., D-J Proj. F-26-R-1, Job I. 8 pp.

Many of the project records were destroyed by a fire, and so much of the report is written from memory. The objective of the project was to develop muskellunge culture techniques that would enable Tennessee to raise enough muskellunge from eggs to stock in reservoirs.

Bishop, R. D. 1965 b

Muskellunge investigations. Reservoir evaluation and selection. Tennessee Game Fish Comm., D-J Proj. F-26-R-1, Job 2. 4 pp.

Bishop, R. D. 1966

Muskellunge investigations. Tennessee Game Fish Comm., D-J Proj. F-26-R-3, Fin. 17 pp.

Bishop, S. C. 1946

An alleged new species of muskellunge. Copeia 1946(1): 43.

Calls attention to Godfrey's 1945 description in Outdoors of a supposed new species of muskellunge, Esox amentus. Figure of mounted specimen is said to resemble supposed hybrids between Chautauqua and St. Lawrence muskellunge.

Bissett, E. D. R. 1927

Fresh-water fish of Manitoba. Can. Field-Nat. 41(6): 127-128.

The muskellunge is included in this list of fishes observed in Manitoba.

Black, J. D. and L. O. Williamson 1947

Artificial hybrids between muskellunge and northern pike. Trans. Wisconsin Acad. Sci. Arts Lett. (1946) 38: 299-314.

Report on a study to determine the value of the Esox masquinongy $\times$ Esox lucius hybrid. Reviews the literature and findings on Esox hybrids. All the hybrids used for the study were produced in Woodruff Hatchery, Wisconsin. The following characteristics of Esox masquinongy, Esox lucius, and $E . m . \times E .1$. hybrids are compared: mandibular pores, branchiostegal rays, measurements and proportions, check scales, colour and pattern, fertility and sex ratio, and natural hybrids. Several photographs of the parents and hybrids are included. Summarizes the results.

Black, R. D. 1934

Charles Fothergill's notes on the natural history of eastern Canada, 1816-1837. Trans. R. Can. Inst. 20(43): 141-168.

The muskellunge (considered a large and delicious species of pike) is a member of the Rice Lake fauna.

Bligh, E. G. 1971

Environmental factors affecting the utilization of Great Lakes fish as human food. Limnos 4(1):

13-19. [Fish. Res. Board Canada Interpretive Art. 201.]

Mercury levels found in muskellunge from Lake St. Clair. 
Boldyreff, E. B. 1935

A microscopic study of the pancreas in fishes; especially those of the Orders Haplomi and Cyprinodontes. Copeia 1935(1): 23-34.

Contains an abridged classification of the fishes studied. The pancreas is described for both Esox masquinongy masquinongy and for Esox masquinongy immaculatus and that of $E . m$. $i$. is said to have some structural differences.

Bonin, J. D. MS 1976

The physiological ecology of larval muskellunge and norlunge: temperature tolerance and growth rates under hatchery conditions. New York State Univ. Buffalo, M.A. thesis. 30 pp.

Bonnycastle, D. 1906

A camera study of the maskinonge. Canadian Mag., September: 392-397.

Botsford, H. 1956

Muskies are mean. Field Stream, August: 81-84, 86.

Boucher, P. 1964

Histoire véritable et naturelle des moeurs et production du pays de la Nouvelle-France, vulgairement dite le Canada. Reprint ed. Société Historique de Boucherville. [Paris, F. Lambert, 1664.] $415 \mathrm{pp}$.

Author interprets the 1664 remarks of Boucher on Brochet as probably based on E. lucius and $E$. masquinongy.

Boulenger, E. G. 1931

Fishes. London, Chapman and Hall. 174 pp.

Size of the largest pike, Esox masquinongy, which occurs in North America.

Bowers, R. R. 1958

The mountain state's unexpected muskies. Fisherman, March: 15-17, 67-70.

Brabant, J. 1977

Musky fishing. New York Dep. Environ. Conserv. 31(5): 21-27.

Bradshaw, H. 1969

A madness for muskies. Field Stream, March: 66-67, 138-140, 152.

Branham, L. 1972

Muskies down in Dixic. Field Stream, May: 54-55, 84, 88.

Bredemus, R. N. 1970

Fishing the Upper Chippewa. Wisconsin Conserv. Bull., March/April: 18-20.

Breder, C. M., Jr. 1925

On the feeding behavior of fishes with terminal mouths. Copeia 149: 89-91.

The author attempts to explain the feeding action of members of the genus Esox mentioned by Weed (1925). The various fish feeding in this way are compared.

Breder, C. M., Jr. and D. E. Rosen 1966

Modes of reproduction in fishes. Published for Am. Mus. Nat. Hist. by Garden City, New York, Nat. Hist. Press. 941 pp.

Short note on breeding habits of the muskcllunge. (p. 137)

Brewer, D. 1967

Musky studics. Kentucky Dcp. Fish Wildl. Res. Div. Fish. Annu. Rep.: 7-8. 
Brewer. D. L. 1968 a

Musky studies. Musky distribution in Kentucky. Kentucky Dep. Fish Wildl. Resour., D-J Proj. F-31-R-1, wk, pl. 1, Job A. 10 pp.

Brewer. D. L. 1968 b

Age and growth studies. Musky studies. Kentucky, D-J Proj. F-31-R-1, wk, pl. 1, Job E: 47-50.

Total lengths, weights, and scale samples were taken from 21 sub-adult or adult muskellunge. With the aid of a microprojector scales were read from all 21 muskellunge.

At the end of their first year, most muskellunge will have a total length of 7 to 9 inches (178 to $229 \mathrm{~mm}$ ). Most will be 15 to 17 inches long $(381$ to $432 \mathrm{~mm}$ ) at two years; 22 to 24 inches (559 to $600 \mathrm{~mm})$ at three years; 28 to 31 inches $(711$ to $787 \mathrm{~mm}$ ) at four years; and 33 to 35 inches $(838$ to $889 \mathrm{~mm})$ at five years.

Brewer. D. L. 1968 c

Musky studies. Age and growth studies. Kentucky Dep. Fish Wildl. Resour., D-J Proj. F-31-R-1, wh. pl. 1, Job E. 4 pp.

Brewer, D. L. 1969

Musky studies. Spawning studies. Kentucky Dep. Fish Wildl. Resour., D-J Proj. F-31-R-2, wh. pl. 2, Job C. 17 pp.

Brewer, D. L. 1970 a

Musky studies. Spawning studies. Kentucky Dep. Fish Wildl. Resour., D-J Proj. F-31-R-3, w.k. pl. 3, Job C. 15 pp.

Brewer, D. L. 1970 b

Musky studies. Physical-chemical-biological studies. Kentucky Dep. Fish Wildl. Resour., D-J Proj. F-31-R-3, wk. pl. 3, Job D. 15 pp.

Brewer, D. L. 1970 c

Musky studies. Age and growth studies. Kentucky Dep. Fish Wildl. Resour., D-J Proj. F-31-R-3, wk. pl. 3, Job E. 33 pp.

Brewer, D. L. $1970 \mathrm{~d}$

Muskies studies. Kentucky Dep. Fish Wildl. Resour. Annu. Job Prog. Rep. 38 pp.

Brice, J. J. 1898

A manual of fish culture, based on the methods of the United States Commission of Fish and Fisheries, with chapters on the cultivation of oysters and frogs. U.S. Comm. Fish. Rep. (1897) Appendix. 340 pp.

Bridges, W. 1970

The New York Aquarium book of the water world. A guide to representative fishes, aquatic invertebrates, reptiles, birds, and mammals. New York Zool. Soc., American Heritage Press. $287 \mathrm{pp}$.

The muskellunge is briefly mentioned. Black and white photograph. (p. 50)

Brooks, J. 1970

Weekend in Carlisle. Outdoor Life 145(2): 76-77, 82-85.

Brooks, J. 1972

Five surface smashers. Outdoor Life 149(6): 54-55, 130-131, 138

Brown, A. 197!

Muskies in Milwaukee's backyard. Fish. Hunting Guide, March: 22-23. 
Brown, E. 1969

Muskies anyone? Fur-Fish-Game, April: 32-33.

Brown, E. 1971

The river musky. Sports Recreation, March/April: 47.

Brown, E. H. 1962

Evaluation of muskellunge stocking. Ohio Div. Wildl., D-J Proj. F-29-R-1, Job Completion Rep. 19 pp.

Brown, J. J. 1876

The American angler's guide. 5th ed. New York, D. Appelton. 428 pp.

Describes the muskellunge, (Essex estor).

Brown, R. R. 1910

Chautauqua hatchery. pp. 317-318. In Bean, T. H. Report of the state Fish Culturist. New York For. Fish Game Commr. 13th, 14th, 15th Annu. Reps. (1907, 1908, 1909): 308-357.

Number of muskellunge fry planted from Chautauqua Hatchery, New York. Explains losses caused by transporting in polluted water.

Brumsted, H. B. and T. F. Horn In Press

A survey of Chautauqua Lake muskellunge fisheries. New York Dep. Nat. Resour., Comell Univ.

Bryant, G. W. 1954

Musky fishing tricks. Am. Woodsman, September: 17, 34

Buie, G. D. 1963

Omemee - Home of Ontario's first muskie hatchery. Outdoorsman 2(1): 40.

The first known instance of artificial propagation of muskellunge in Ontario is reported.

Burch, R. T. 1967

Hunting muskies. Fish. World, July/August: 42-45.

Burnett, W. I. 1854

(Note on breeding of muskellunge.) Proc. Boston Soc. Nat. Hist. 4: 360.

Buss, K. 1960

The muskellunge. A literature survey of the life history and culture of the muskellunge. Pennsylvania Fish Comm. Benner Spring Fish Res. Stn. Spec. Purpose Rep. 14 pp. Mimeograph.

Summarizes much of the literature published to that time. The following subjects are discussed: value as a sport fishery, origins of common and scientific names, subspecies and distribution, fossil history, spawning, development, age and growth, record size, food and feeding, habitat and habits, predation, culture, management, economic importance, hybrids. Includes a bibliography.

Buss, K. 1961 a

Record muskellunge - fact or fiction. Pennsylvania Angler 30(6).

Many of the stories about record-size muskellunge are unauthenticated and therefore may not be factual. Several "musky stories" are retold and some authenticated records are given.

Buss, K. 1961 b

The northern pike. Pennsylvania Fish Comm. Spec. Purpose Rep. 58 pp.

Buss, K. 1965

Pennsylvania's muskellunge program. Pennsylvania Fish Comm. Conserv. Educ. Div. 11 pp. [Reprinted from Pennsylvania Angler 30(8-9), 1961.] 
Written to inform the public about the muskellunge stocking programme in Pennsylvania. Describes methods used to improve muskellunge angling and to utilize the fish as a predator species. There is a section giving angling information.

Buss, K. 1966

Research and fish management. In Smith, J. M. Division reports to the sportsman. Pennsylvania Angler 35(1): 22-24.

Buss, K. and J. Miller 1961 a

The age and growth of the muskellunge in Pennsylvania. Part 7. Pennsylvania Angler 30(4): $10-11$.

Data presented on age and growth of the muskellunge. Data obtained from Benner Spring, Pennsylvania, records.

Buss, K. and J. Miller $1961 \mathrm{~b}$

The age and growth of the muskellunge. Part 7. Pennsylvania Fish Comm. Benner Spring Fish Res. Stn. 2 pp. [Reprinted from Pennsylvania Angler 30(4), 1961.]

Short discussion of the voracity and rapid growth rate of the muskellunge. Tables of length-weight data for 143 muskellunge and average total length per year class for Pennsylvania.

Buss, K. and J. Miller 1967

Interspecific hybridization of esocids: hatching success, pattern development, and fertility of some $F_{1}$ hybrids. U.S. Dep. Inter. Fish Wildl. Serv. Bur. Sport Fish. Wildl. Tech. Pap. 14. 30 pp.

The literature is reviewed and success of reciprocal crosses is recorded, including drawings and photographs showing the development of progeny. Fertility of $F_{1}$ hybrids was investigated. Five esocids including muskellunge were used to make 20 reciprocal crosses.

Cahn, A. R. 1927

An ecological study of certain southern Wisconsin fishes. Illinois Biol. Monogr. 11(1): $7-151$.

The muskellunge has been extinct in the Oconomowoc-Waukesha Lake district of southern Wisconsin for the last 30 years but there is little doubt that it once occurred in the Fox River. A 40-pound $(18.1 \mathrm{~kg})$ individual was caught in 1877 .

Caine, L. S. 1949

North American fresh water sport fish. A. S. Barnes. 212 pp.

General notes on angling, colloquial names, coloration, characteristics, range, habitat, size, flavour, natural foods, artificial lures, methods of angling.

Caine, L. S., ed. 1950

Muskellunge Esox masquinongy. Heddon Fish-Flashes, Release 142. 5 pp.

Cameron, G. S. no date

A taxonomic study of the maskinonge with special reference to the so-called "True-tiger" maskinonge. R. Ontario Mus. Zool. 7 pp. Mimeograph.

A study of specimens from the Kenora and Rainy River districts thought to be a subspecies (Esox masquinongy immaculatus). The following information was recorded: age with colour and markings, meristics and morphometrics (table), scutellation, sexual dimorphism (female said to be larger), and sex ratio (female to male, 2 to 1 ).

Also found in this area is the tiger musky at that time given the scientific name Esox amentus, for which very similar information was recorded. The two forms $(E, m . i$. and $E . a$.) were compared. Explanations given for the difference, including the possibility that the tiger musky is a hybrid. 
Cameron, G. S. 1948

An unusual maskinonge from Little Vermilion Lake, Ontario. Canadian J. Res. 26: 223-229.

An unusual type of muskellunge was regarded as a hybrid between Esox masquinongy and Esox lucius. This type differs in having a stouter body, longer and deeper head, longer maxillary, and longer fins. Retains dark vertical bars throughout life. Of 69 specimens examined, six were of the presumed hybrid type. They all appeared to be sterile.

Camp, R. R. 1951

Reel sport: pike, pickerel and musky. Colliers Mag., July: 30-31, 60-61.

Campbell, D. 1958

The muskellunge in Pennsylvania. Pennsylvania Angler 27(6).

Canfield, H. S. 1901

Mascalonge in the Flambeau waters. Outing Mag., September: 707-710.

Carbine, W. F. 1938

The pike. Both a prized and spurned fish. Michigan Conserv. 7(12): 6-8.

The characteristics of Esox masquinongy are briefly described.

Carhart, A. H. 1932

The fighting pike. Nature Mag., October: 155-158.

Carlander, K. D. 1948

Some changes in the fish population of Lake of the Woods, Minnesota, 1910-1945. Copeia 1948(4): 271-274.

Esox masquinongy immaculatus was collected from Lake of the Woods, Minnesota.

Carlander, K. D. 1952

Vital statistics on the pike family. Field Stream, February.

Carlander, K. D. 1969

Handbook of freshwater fishery biology. Life history data on freshwater fishes of the United States and Canada, exclusive of the Perciformes. Vol. 1. Iowa Univ. Press. $752 \mathrm{pp}$.

Tabulated data surveys of much of the available information on growth, length, weight, age, reproduction, culture, and hybrids of muskellunge. Gives extensive references to the literature. (pp. 354-363).

Carlander, K. D. and L. E. Hiner MS 1943

Preliminary report on fisheries investigations Leech Lake, Cass County. Minnesota Bur. Fish. Res. 18 pp. Manuscript.

Carlson, H. E. $\quad 1966$

Muskies at night. Field Stream, July: 36-37, 70-72.

Carroll, D. 1917

Lake and stream game fishing. A practical book on the popular fresh-water game fish, the tackle necessary and how to use it. Cincinnati, Stewart and Kidd. 253 pp.

Full of fish lore, this book was written primarily for the avid angler. Much of the contents is of doubtful accuracy, such as the statement that muskellunge shed their teeth in August. (pp. $90-94,133-137,165-203,218-219$ )

Cartier, J. O. 1967

Don't bet on a muskie. Outdoor Life 139(6): 50-51, 112-114.

Cary, B. 1968

The sawtooth terror. Fish. World, November/December: 45-49, 60-61. 
Casselman, J. M. 1975

Cleithral method of determining age and growth of northern pike and other esocids. Toronto,

Canada, Proc. 37th Midwest Fish Wildl. Conf., December 7-10, 1975.

The cleithral method of determining age and growth of muskellunge is presented for specimens from the upper St. Lawrence River.

Castle, J. 1964

Man, it's muskyville. Fur-Fish-Game, April: 7-9.

Cavender, T. M. 1969

An Oligocene mudminnow (family Umbridae) from Oregon with remarks on relationships within the Esocoidei. Univ. Michigan, Mus. Zool. Occas. Pap. 660. 33 pp.

An Oligocene mudninnow. Novumbra oregonensis, is described and compared to the esocoids, including brief mention of Esox masquinongy.

\section{Cavender, T. M., J. G. Lundberg and R. I. Wilson 1970}

Two new fossil records of the genus Esox (Teleostei, Salmoniformes) in North America. Northwest Sci. $44(3)$ : 176-183.

Although $E$. masquinongy, $E$. americanus, and $E$. niger are endemic to North America, the fossil record has provided little evidence of their evolutionary history. Included is a distribution map showing both today's boundaries and fossil locations. Discusses depressible type of palatine tooth (common to esocids) and differences between species.

Cernohous, L. 1974

Diet tests on walleye, northern pike and muskellunge. North Dakota Bur. Sport Fish. Wildl. Div. Fish Hatcheries, Valley City Natl. Fish Hatchery. Mimeograph.

Chamberland, R. B. 1946

Our muskies. Twinsburg, Ohio, Manuscript Booklet. 38 pp.

Comprehensive booklet on the biology and habits of the muskellunge, with emphasis on angling.

Chambers, E. T. D. 1904 a

Fish and fishing: "maskinongé" is its name. For. Stream 62: 212.

Chambers, E. T. D. 1904 b

Maskinonge or mascalonge. For. Stream 62: 316.

Chambers, E. T. D. 1923

The maskinonge: a question of priority in nomenclature. Trans. Am. Fish. Soc. (1922) 52: 171-177.

Discusses the origins of the various common names given to the muskellunge and reasons for the author's view that it should be called maskinongé. Cites several capture records and angling methods. Also see discussion of paper.

Chambers, K. J. 1963

Lake of the Woods survey. Northern sector - 1963. Preliminary report. Ontario Dep. Lands For. Rep. 65 pp.

Muskellunge encountered in the northern sector of Lake of the Woods during the 1963 study. Although there was no record of muskellunge taken by anglers from the creel census data, it was netted during the study period. For captured fish the following information is given: age, average fork length, pounds per trap net, and number per trap net.

Chapman, C. R. 1955

Sandusky Bay report. Ohio Div. Wildl. 84 pp.

Management notes mention muskellunge. 
Chapralis, J. C. 1954

A lunge for a musky. Am. Woodsman, June: 16-17, 24-25.

Chapralis, J. C. 1964

Muskie on his back. Field Stream, September: 70-71, 105-106, 125, 127, 129, 138.

Chapralis, J. C. 1969

The musky itch . . . and how to cure it! Annu. Midwest Fish. Guide: 32-33, 93-94.

Cheney, A. N. 1896

Mascalonge, pike, pickerel and pike-perch. New York Comm. Fish. Game For. 1st Annu. Rep. (1895): 121-124.

Identification of Lucius masquinongy by cheek and gill scalation. Notes on artificial propagation, Chautauqua Lake, New York.

Cheney, A. N. 1897 a

Concerning the work of the Fisheries, Game and Forest Commission of the State of New York. Trans. Am. Fish. Soc. 25: 112-120.

Cheney, A. N. 1897 b

Mascalonge, pike, pickerel and pike-perch. For. Stream, May: 29.

Cheney, A. N. 1898 a

A synopsis of the history of fish culture. New York Commr. Fish. Game For. 3rd Annu. Rep.: 191-198.

Briefly describes muskellunge eggs and method of hatching.

Cheney, A. N. 1898 b

The pikes. For. Stream 50(17): 330-331.

Choquette, L. P. E. 1951

Parasites of freshwater fish. V. Parasitic helminths of the muskellunge, Esox m. masquinongy Mitchill, in the St. Lawrence watershed. Can. J. Zool. 29: 290-295.

Eight species of helminths were recovered from the digestive tract of muskellunge taken from the St. Lawrence watershed. Eighty-eight per cent of the muskellunge examined contained one or more parasite species, but in all cases the number was small.

Churchill, W. S. 1950

Experimental stocking of predators for population control. Wisconsin Div. Fish. Manage. Invest. Rep. 728.8 pp.

Churchill, W. S. 1962 a

Warm water fishery research. Five lakes studies. Creel census of Escanaba, Pallette, Nebish, Spruce and Mystery Lakes. Wisconsin Conserv. Dep., D-J Proj. F-61-R-2, wk. pl. 5, Job A: $1-2,11-12$.

Churchill, W. S. 1962 b

Warm water fishery research. Five lakes studies. Evaluation of maintenance stocking of walleye fingerling. Wisconsin Conserv. Dep., D-J Proj. F-61-R-2, wk. pl. 5, Job D: 6, 22-26.

Churchill, W. S. 1968

Muskellunge fishing in Wisconsin. Wisconsin Dep. Nat. Resour. Surv. Rep. 8 pp. Mimeograph.

Churchill, W. S. and H. Snow 1964

Characteristics of the sport fishery in some northern Wisconsin lakes. Wisconsin Conserv. Dep. Tech. Bull. 32. 46 pp. 
Deals primarily with anglers. The muskellunge is one of the fish species present in the area studied.

Circle, $H$. no date

Muskellunge Esox masquinongy. Heddon Fish-Flashes, Release 54J. 3 pp.

Circle, H. 1970

The musky mystique. Sports Afield, June: $33-35,150,152-154$.

Claflin, B. 1943

The muskie hangs high. Field Stream, July: 20-21, 56.

Claflin, B. 1945

Musky fishing. A Borzoi Book, A. A. Knopf.

Clark, C. F. 1964 a

Muskellunge in Ohio and its management. Ohio Dep. Nat. Resour., Div. Wildl. Publ. W-329. $14 \mathrm{pp}$.

A comparison of history, commercial fishery, and attempts at culture in the Great Lakes.

Clark, C. F. 1964 b

Muskellunge in Ohio and its management. Ohio Div. Wildl., D-J Proj. F-29-R. 18 pp.

Clark, G. 1947

With rod and reel in Canada. Ottawa, Canadian Gov. Travel Bur. 40 pp.

Clark, G. 1955

Game fish in Canada. Ottawa, Canadian Gov. Travel Bur. 28 pp.

Clark, G. and C. H. May, eds. no date

A line on fishing. Toronto, Stewart Publ. $36 \mathrm{pp}$.

Colour illustration of the muskellunge is accompanied by a short descriptive note outlining sporting qualities, distribution, habitat, identification, and variations in name.

Clark, T. L. 1974 a

Muskellunge nursery ponds in Pennsylvania. Morehead, Kentucky, Proc. 6th Interstate Muskellunge Workshop, September 25-26: 48-49. Mimeograph.

Describes the ponds used to rear muskellunge in Pennsylvania.

Clark, T. L. 1974 b

Intensive culture of muskellunge in Pennsylvania. Morehead, Kentucky, Proc. 6th Interstate Muskellunge Workshop, September 25-26: 66-68. Mimeograph.

Describes method used to raise muskellunge in hatcheries in Pennsylvania.

Clark, T. L. 1975

Rearing of walleye and tiger muskellunge at the Corry/Union City Fish Cultural Stations in 1975. La Crosse, Wisconsin, Proc. 7th Interstate Musky Workshop, September 30-October 1: 60-67. Mimeograph.

Describes the rearing facilities and rearing techniques used to culture artificially walleye and the hybrid (Esox masquinongy $\times E$. lucius) at the Corry and Union City Hatcheries.

Clarkson, E. P. 1963

The tiger of Lake Chautauqua. Motor Boating, July: 82, 90-91, 93.

Clay, S. 1971

Action float for bluegrass musky. Fish. Hunting Guide, June: 10-11. 
Clay, S. 1973

Kentucky for muskie. Fur-Fish-Game, April: 20-22.

Clay, W. M. 1962

A field manual of Kentucky fishes. Kentucky Dep. Fish Wildl. Resour. 147 pp.

Brief description of characteristics, range, and preferred habitat is accompanied by a black and white drawing. (pp. 16,43-44)

Clay, W. M. 1975

The fishes of Kentucky. Kentucky Dep. Fish. Wildl. Resour. 416 pp.

Brief note contains an illustration and information on description, range, distribution in Kentucky, distinguishing features, and former abundance of the muskellunge.

Cleary, R. E. 1956

The distribution of the fishes of Iowa. pp. 267-324. In Harlan, J. R. and E. B. Speaker. Iowa fish and fishing. 3rd ed. Iowa Conserv. Comm. 377 pp.

Esox masquinongy is one of the species considered extinct in lowa.

Clinton, D. 1815

Some remarks on the fishes of the western waters of the State of New York in a letter to S. L.

Mitchell, M. D. Trans. Lit. Philos. Soc. New York (1814) 1: 493-501.

Includes brief mention of the muskellunge.

Colesante, R. 1974

Summary of 1974 muskellunge fry studies in New York State. Morehead, Kentucky, Proc. 6th Interstate Muskellunge Workshop, September 25-26: 45-47. Mimeograph.

Brief point-form note outlines data collected, which indicate massive mortalities of muskellunge sac fry may have been caused by a bacterial pathogen, Pseudomas sp.

Colesante, R. T. 1977

Behaviour of muskellunge fry during yolk absorption and swim-up. New York Fish Game J. 24(1): 94 .

Colesante, R. T. and R. Engstrom-Heg 1975

Report on 1975 muskellunge fry studies. New York Dep. Environ. Conserv. Bur. Fish., D-J Proj. F-9-R. 40 pp.

Collins, D. L. 1929

Old Black Joe. For. Stream, March: 178, 213.

Collins, H. H., Jr. 1959

Complete field guide to American wildlife. East, central and north. New York, Harper Publ. $683 \mathrm{pp}$.

Brief note mentions description, habits, and range of the muskellunge. Small colour illustration.

Connor, J. 1955

Five crazy days. Outdoor Life 116(5): 30-31, 34-35.

Connor, J. 1956

Fishing the moody monster. Sports Afield, July: 37-39, 79-81.

Cooper, A. R. 1918

North American pseudophyllidean cestodes from fishes. Illinois Biol. Monogr. 4: 288-541. 
Cope, E. D. 1865

Partial catalogue of the cold-blooded vertebrata of Michigan. Part 2. Proc. Acad. Nat. Sci. Philadelphia 17: 78-88.

Key to species of Esox as they were known, including $E$. nobilior. Includes synonymy and literature references.

Cope, E. D. 1869

Supplementary synopsis of the Esoces of middle North America. Trans. Am. Philos. Soc. 13(2): $407-410$.

Key to esocid species. Synonymy of Esor nobilior.

Cotchefer, R. 1902

Repon of the General Foreman of hatcheries. New York For. Fish Game Comm. 7th Annu. Rep. (1901): 58-61.

Report on the taking of eggs for the Chautauqua Lake Hatchery, New York.

Cotchefer, R. 1904

The maskalonge supply. Report of the General Foreman of hatcheries 1902. New York For. Fish Game Comm. 8th, 9th Annu. Reps. (1902, 1903): 83.

Winter spearing had greatly depleted muskellunge, and number of fry taken from Chautauqua Lake, New York, each year was decreasing.

Couch, C. 1947

Twelve years for a muskie. Field Stream, October: 24-25, 141.

Popular article about a fisherman's catching a muskellunge after twelve years of angling.

Couey, F. M. 1935

Fish food studies in a number of north eastern Wisconsin lakes. Trans. Wisconsin Acad. Sci. Arts Lett. 29: 131-172.

Coulloudon, J. 1960

Etiquetage d'esocides au moyen d'injections de latex liquide coloré. Québec Minist. Chasse Pêch. J. Bord 3(66): 558-560.

Explains a method of marking muskellunge and pike with red- and blue-coloured latex injections. Photograph showing method.

Coulloudon, J. 1965

Analyse des estomacs de maskinongés récoltés au cours des saisons 1959-1960. Québec Minist. Chasse Pêch. J. Bord 3(65): 548-550.

Analysis of stomach contents of muskellunge through the period 1959-1960. The fish were captured on a fishing line by trolling with artificial bait, casting with both natural and artificial bait, and still fishing with live bait. A map is included, which shows distribution.

\section{Coulloudon, J. et R. Couture 1961}

Expérience sur la croissance du maskinongé. pp. 14-45. In Prévost, G., ed. Contribution de la Station Piscicole de Lachine à l'étude du maskinongé. Québec Minist. Pêch. Pêche, Suppl. Trimestriel J. Bord. 55 pp.

This article contains valuable data obtained while rearing muskellunge. Included are graphs, tables, and mathematical formulae.

Courtemanche, A. MS 1963 a

Maskinongés capturés dans le lac Saint-Louis par M. Emile Pilon de Sainte-Anne-de-Bellevue, co. Jaques-Cartier, Québec de 1918 à 1927. Montréal, Québec. 9 pp. Manuscrit.

Summarizes catch statistics and presents the data in graphs and tables. 
Courtemanche, A. MS 1963 b

Maskinongés capturés en 1962, dans le lac Maskinongé, Saint-Gabriel-de-Brandon, et inscrits au concours de pêche Molson. Montréal, Québec. 15 pp. Manuscrit.

The following information is given for fish entered in the Molson Fish Contest: date and hour of capture, method of fishing, type of lure, weight, length, circumference, and name of fisherman. This information is discussed. A length-weight relationship W-L $=23$ was deduced from the graphs.

Courtemanche, A. MS 1964

(Maskinongé (Esox masquinongy): répartition au Québec, introductions, pêche.) Québec Minist. Chasse Pêch. 3 pp. Manuscrit.

Copy of correspondence giving a detailed description of muskellunge distribution in Quebec. Includes a map showing main points of distribution. Table listing Molson Fish Tournament entries is also attached

\section{Courtemanche, A. et J.-R. Mongeau 1965}

La distribution du maskinongé dans le Québec, 1964. Québec Minist. Tourisme Chasse Pêche Serv. Faune. Carte.

\section{Courtemanche, A., J.-R. Mongeau, G. Pageau et L. Deschamps MS 1963}

Maskinongé et sa maturité, doré, barbotte: capturés au filets; carte bathymétrique; lac Maskinongé, Saint-Gabriel-de-Brandon, co. Berthier, Québec, 31 mai - ler juin, 1963. Québec Minist. Tourisme Chasse Pêche Serv. Faune. 8 pp. Manuscrit.

Study undertaken to determine if the muskellunge had spawned and if not to obtain gametes for incubation in the Lachine fish culture station. Also undertook to obtain some specimens for the collection. However, all the fish taken in the first netting were males.

\section{Couture, R. 1964}

Age et croissance du maskinongé (Esox masquinongy) du lac Donaldson, 1961-1962. Travaux en cours en 1963. Québec Minist. Tourisme Chasse Pêche Serv. Faune Rapp. 3: 28-35.

Specimens of muskellunge captured in Lake Donaldson were measured and weighed. Specimens were also aged from scale samples. Data that resulted from these investigations are tabled and discussed.

Couture, R. 1972

Liste annotée des poissons de la rivière Châteauguay et des ses affluents. Québec Minist. Tourisme Chasse Pêche Serv. Faune Rapp. 6: 385-404.

Gives reported captures of muskellunge from the Chateauguay River.

Couture, R. et Y. Gravel MS 1962 a

Une pisciculture à maskinongé est-elle rentable. Québec Minist. Chasse Pêch. Serv. d'Aménagement Faune. 6 pp. Manuscrit.

Discusses methods of lessening the cost of muskellunge culture and increasing production.

Couture, R. et Y. Gravel MS 1962 b

Rapport sur les activités de la pisciculture de Lachine en 1962. Québec Minist. Chasse Pêch. Serv. d’Aménagement Faune. 8 pp. Manuscrit.

Outlines method used by the Lachine hatchery. Planting records are presented in a table.

Couture, R. et Y. Gravel 1965

Une pisciculture à maskinongé est-elle rentable? Québec Minist. Tourisme Chasse Pêche Serv. Faune Rapp. 5: 255-259.

Cross, H. 1943

Smell of muskie. Outdoor Life 94(3): 24-25, 79-81. 
Crossman, E. J. MS 1954 a

The maskinonge population of Nogies Creek, Ontario. Univ. Toronto, M.A. thesis. 74 pp.

Population estimates by Schumacher, Schnabel, Peterson methods from numbered tag recoveries of muskellunge taken in six foot trap nets.

Supplementary notes on movements, size, age, growth, and mortality.

Crossman, E. J. MS 1954 b

The movement of tagged maskinonge in Nogies Creek, Ontario. Queen's Univ., Ontario Res. Council Tech. Sessions, 6 pp. Manuscript.

Muskellunge in Nogies Creek were captured in trap nets and tagged to determine movements. Results indicate great variability in time out to distance travelled; tendency in the summer was toward little movement. Some correlation is made between size, age, and direction and distance travelled. Two interesting incidents of muskies' travelling great distances are described.

Crossman, E. J. 1956

Growth, mortality and movements of a sanctuary population of maskinonge (Esox masquinongy Mitchill). J. Fish. Res. Board Canada 13(5): 599-612.

A Schumacher population estimate based on 995 muskellunge set the number at between 769 and 1,122 in July 1953. The mean standard length of these fish was $53.0 \mathrm{~cm}$. The rate of growth $(26.3 \mathrm{~cm} \mathrm{~S}$. L. in the first year) compared favourably with that for muskellunge in other waters. The small number of fish over four years of age was apparently due to a 70 per cent annual mortality rate at least after the third year of life and perhaps before age 111 .

Recaptures of tagged muskellunge demonstrated that there was little movement in summer, but in the fall there was far more movement of fish.

Crossman, E. J. 1960

Variation in number and asymmetry in branchiostegal rays in the family Esocidae. Can. J. Zool. 38(2): 363-375.

Gives variations in branchiostegal ray numbers, usual numbers, number of epihyoid and ceratohyoid, bilateral asymmetry, and aberrations in number and location for all esocids including E. masquinongy.

Crossman, E. J. 1962 a

The grass pickerel Esox americanus vermiculatus LeSueur in Canada. R. Ontario Mus. Life Sci. Div. Contrib. 55. 29 pp.

Characters to separate esocids. Drawings of Esox masquinongy.

Crossman, E. J. 1962 b

The redfin pickerel, Esox a. americanus in North Carolina. Copeia 1962(1): 114-123.

Compares the difference in the egg counts of the redfin and grass pickerel and the muskellunge and pike.

Crossman, E. J. 1962 c

Predator-prey relationships in pikes (Esocidae). J. Fish. Res. Board Canada 19(5): 979-980.

Short note on the predator-prey relationships of the esocids indicates variability in prey selection between the species. Yellow perch and common suckers were prominent in the diet of muskellunge, Esox masquinongy. However, the wide range of fish and other vertebrates consumed made this appear to be selection by size and not by species.

Crossman, E. J. 1969

The Canadian freshwater fish fauna. Ac. Rer. Nat. Mus. Nat. Slov. Bratislava 15(2): 137-152.

The muskellunge is listed as a so-called endangered species. 
Crossman, E. J. 1971

Pike. Related forms and history. Appendix 2, pp. 292-307. In Buller, F. Pike. London, Macdonald. 320 pp.

In this appendix appearing in a book on the pike, there is a short discussion of the muskellunge. Points out differences from the pike. General information on size, growth, distribution. abundance, habitat, preferred food, angling, and attributes as a food fish.

Crossman, E. J. 1975

Musky! ROM research on an important sport fish. Rotunda 8(1): 36-40.

A popular article describing a Royal Ontario Museum research project under way to investigate the muskellunge by telemetry.

Crossman, E. J. and K. Buss 1965

Hybridization in the family Esocidae. J. Fish. Res. Board Canada 22(5): 1261-1292.

Reviews published data on hybrids of species of esocids and adds new data as a result of artificial crosses made at Benner Springs Research Station, Pennsylvania. Information is given on description, growth, fertility, and vitality of the following muskellunge hybrids: Esox masquinongy $\times$ Esox lucius; Esox masquinongy $\times$ Esox niger; Esox masquinongy $\times$ Esox americanus americanus; E. masquinongy $\times$ Esox americanus vermiculatus.

\section{Crossman, E. J. and J. M. Casselman 1969}

Identification of northem pike and muskellunge from axial skeletons, scales, and epipleurals. J. Fish. Res. Board Canada 26(1): 175-178.

Grooves and knobs on the vertebrae, ratio of length and width of scales, and ratio of lengths or rami of epipleural bones enabled us to separate northern pike and muskellunge in mutilated specimens, stomach contents, and archaeological material. (Authors' abstract)

Cuerrier, J.-P. 1948

La pêche commerciale dans les eaux douces du Québec. Carnets Soc. Zool. Québec 8(3): $1-11$.

The muskellunge is listed as one of the principal sport fishes of Quebec.

Cuerrier, J.-P., F. E. J. Fry et G. Préfontaine 1946

Liste préliminaire des poissons de la région de Montréal et du lac Saint-Pierre. Nat. Can. (Que.) 73: 17-32. [Reprinted in Univ. de Montréal, Contributions de l'lnstitut de biologie générale et de Zoologie 17. 16 pp.]

Esox masquinongy is one of the fishes common in the Montreal region but it is not abundant.

Cull, J. L., ed. 1934

The 'lunge, pike and pickerel. Rod Gun Canada 35(10): 27-28.

Describes the muskellunge and gives angling hints.

Cuvier, M. le B. et M. A. Valenciennes 1846

Histoire naturelle des poissons. Vol. 18. Paris, P. Bertrand. 505 pp.

A specimen from Lake Erie was described. Describes dentition in some detail. Information is given on distribution, feeding, common names, discussion of literature, and comparison with pike.

Czura, P. 1971

Hell on a hook. Sportfishing, November/December: 16-17, 29-30.

Daley, S. A. 1973

Report of muskellunge management in Minnesota (1972). Minnesota Dep. Nat. Resour. Div. Game Fish. Sect. Fish. 
Daley, S. A. 1974

Report of muskellunge management in Minnesota - 1973. Morehead, Kentucky, Proc. 6th Interstate Muskellunge Workshop. September 25-26: 50-54. Minreograph.

Brief outline of culture and stocking of muskellunge in Minnesota, giving costs and method. Summary of distribution of hatchery fish in the state.

Dalrymple, B. W. 1961

Dark secret. Outdoor Life 128(1): 78-79, 86-89.

Dairymple, B. 1962

The nusky fever strikes. Fish. World. June: 19-24.

Dalrymple, B. 1968

Sportsman's guide to game fish. A field book of fresh- and saltwater species. Outdoor Life Books. New York. Cleveland. World Publishing. 480 pp.

Muskellunge were planted in Clear Lake, lowa, to balance the yellow bass population, which had overproduced and become stunted. The account on the muskellunge is primarily concerned with angling. There is a colour illustration of the muskellunge. (pp. 45, 61-65, 107)

Davis, H. S. 1953

Culture and diseases of game fishes. Berkeley, Los Angeles, Univ. California Press. 332 pp.

Since muskellunge and pike methods of propagation are essentially the same, they are considered together in section "Propagation of muskellunge and pike". Significant differences between the two species, such as spawning habits and egg peculiarities, are expalined.

The entire process, from capturing ripe fish to take spawn, incubation of the eggs, and rearing of fingerlings, is described. The major problem in rearing these fish is satisfying their voracious appetite so that they do not devour each other.

Davis, W. 1958

Decoy fishing. Outdoor Life 122(5): 70-71, 133, 137-141.

Davis, W. 1961

Truth about muskie fishing. Outdoor Life 128(4): 134-316.

Davis, W. 1964

25 top fishing holes: muskies. Outdoor Life 133(5): 33-35, 97-98.

Davis, W. 1967

Boss of the weedbeds. Outdoor Life 140(4): 114-117, 165.

Davisson, M. T. 1972

Karyotypes of the teleost family Esocidae. J. Fish. Res. Board Canada 29(5): 579-582.

Representatives of all five surviving species in the teleost family Esocidae, including pikes, pickerels, and muskellunge, and two interspecific hybrids, were found to have karyotypes consisting of 50 acrocentric chromosomes. The karyotypic similarity suggests a cytological basis for the ease of hybridization observed among most members of this family and shows that speciation can occur without karyotypic change. Evolutionary implications are discussed. (Author's abstract)

DeBoer, M. J. and J. R. Williams 1954

Meet Mr. "Musky." Michigan Conserv. Bull. 23(4): 12-15.

Dechtiar, A. O. 1972 a

New parasite records for Lake Erie fish. Great Lakes Fish. Comm. Tech. Rep. 17. 19 pp.

One specimen of Esox masquinongy was examined and found to be infected by Ergasilus caeruleus and Diplostomulum flexicaudum, in a larval or immature form. 
Dechtiar, A. O. 1972 b

Parasites of fish from Lake of the Woods, Ontario. J. Fish. Res. Board Canada 29(3): 275283.

Two Esox masquinongy were examined and both found to be infected. Parasites found are listed.

Dechtiar, A. O. 1972 c

Systematic status of Tetraonchus lofrusi n. sp. (Monogenoidea: Tetraonchidae) and comparative studies of $T$. monenteron (Wagener, 1857) Diesing, 1858, and $T$. variabilis Mizelle and Webb, 1953. Can. J. Zool. 50(11): 1489-1495.

A new species of monogenean Terraonchus loftusi $\mathrm{n}$. sp. from the gills of the muskellunge, Esox masquinongy Mitchill, is described. Brief comparative descriptions and discussions of Tetraonchus monenteron (Wagener, 1857) Diesing, 1858 and $T$. variabilis Mizelle and Webb, 1953 are given, extending our knowledge of structure and distribution of these two species.

Decker, E. N. 1922

The colonel and the muskie. For. Stream, November: 490-491, 521.

DeGroot, W. G. 1901

Talks to boys - XV11: muskallunge fishing. For. Stream, May: 4 .

De Kay, J. E. 1842

Fishes. Part 4, pp. 1-415. In Zoology of New-York, or the New-York fauna; comprising detailed descriptions of all the animals hitherto observed within the state of New-York, with brief notices of those occasionally found near its borders, and accompanied by appropriate illustrations. New York Geol. Surv.

Contains a description of Esox estor $=(E$. masquinongy $)$. Although description of colour and markings bears more resemblance to E. lucius, the ray count B $18, \mathrm{D} 20$ or $21, \mathrm{~A} 21$ confirms it as muskellunge.

Derochers, J. $\quad 1895$

Un maskinongé (Esox estor Gill) remarquable. Nat. Can. (Québec) 22: 191-192.

Desrochers, R. et J. Coulloudon 1960

Epizootie de columnaris chez des maskinongés à la pisciculture de Lachine. Québec Minist. Chasse Pêch. J. Bord 3(49): 373-375.

Report of an outbreak of the disease Columnaris on muskellunge in the Lachine Fish Hatchery. The fish were treated with copper sulfate and chlorine. The authors believed the disease was transmitted to the muskellunge from infected fish brought from polluted streams as food for the fry.

Devitt, O. E. 1953

Some age and size records of Ontario maskinonge (Esox masquinongy). Ontario Dep. Lands For. Wildl. Manage. Rep. 9. 1 p. Mimeograph.

Age, fork length, weight, and locality data are given. Aging is considered accurate to one or two years.

Devitt, O. E. 1958

The age and growth rates of Ontario game fishes for fish and wildlife management. Ontario Dep. Lands For. 10 pp. Mimeograph.

Tabular data giving the following information for each age group of 576 muskellunge examined: number examined per age group, average total length, length range, weight average, and weight range.

Dickinson, W. E. 1960

Handbook of Wisconsin fishes. Milwaukee Public Mus. Popular Sci. Handb. Ser. 8. 86 pp. 
Intended to be used as a tool by fishermen, this publication includes keys and drawings to identify fishes, including the Great Lakes muskellunge (Esor masquinongy masquinongy), the northern muskellunge ( $E . m$. immacularus), and pike-muskellunge hybrids.

Dickson, M. 1971

New York's "gravel bar" musky. Fish. Hunting Guide, April: 26-27.

Dieckman, M. 1965

First essentials of musky fishing. Wisconsin Conserv. Bull., July/August: 18-19.

Dieffenbach, R. 1950

A preliminary evaluation report on the fish and wildlife resources in relation to the water development plan for Chautauqua Lake and the Chadokoin River, Allegheny River Sub-basin, Ohio River Basin, N.Y. U.S. Fish. Wildl. Serv. Del. River Basin Stud. 16 pp. Mimeograph.

\section{Drilhon, A., J.-M. Fine et E. Magnin 1961}

Etude des protéines sériques d'Esor lucius et d'Esor masquinongy. C. R. Séances Soc. Biol. 155(3): $451-453$.

Electrophoresis was done with serum from Esox lucius and Esox masquinongy on three different mediums - paper, glucose, and starch gel. The results are compared with human serum results.

Dube, J. A. and C. A. Rettie 1961

Muskie sport fishery, Moon River area, Georgian Bay - fronting Conger Township, 1960. Ontario Dep. Lands For. 2 pp. Mimeograph.

Short summary of creel census data collected on fishing pressure, fishing success, and age-class composition of the muskellunge in the Moon River area. Describes two instances when muskellunge died because of attempting to swallow channel catfish.

Duck, H. 1971

The great muskie hunt. Field Stream, February: 58-59, 94.

Duerre, D. C. 1966

Statewide fisheries investigations. Evaluation of fish rearing areas. North Dakota Game Fish Dep., D-J Proj. F-2-R-12, Job 11, Fin: 80-97.

Dufour, M. 1965

Recherché de nourriture pour le maskinongé: évaluation des populations de ménés dans quelques lacs aux environs de la pisciculture de l'Estrie. Québec Minist. Tourisme Chasse Pêche Serv. Faune Rapp. 5: 23-31.

Dumas, R. F. 1972

Muskellunge culture improvement study. Analysis of the costs of raising muskellunge in New York State. New York Div. Fish Game, D-J Proj. F-27-R-1, wk. pl. 1, Job B. 3 pp.

Dursley, R. S. and F. E. J. Fry 1961

A creel census study of the maskinonge in Pigeon and Sturgeon lakes, 1961. Univ. Toronto, Great Lakes Inst. Preliminary Rep. Ser. 1. 13 pp. Mimeograph.

A creel census was conducted in Pigeon and Sturgeon lakes to determine the contribution to the fishery of muskellunge transplanted from Nogies Creek (tagged or with tag scars) and muskellunge native to these lakes (no tags or tag scars). A tag contest run by the Toronto Anglers and Hunters Association encouraged anglers to report tags found. From the data collected, estimates of mortality rate, age composition of catch, and recovery of planted fish were calculated. 
Dymond, J. R. 1922

A provisional list of the fishes of Lake Erie. Univ, Toronto Stud. Biol. Ser. 20, Publ. Ontario Fish. Res. Lab. 4: 57-73.

Lucius masquinongy listed and distribution given according to Nash (1908).

Dymond, J. R. 1932

About the maskinonge. Rod Gun 34(1): 18.

General note mentions size, markings, names, and reasons for decline in numbers of muskellunge.

Dymond, J. R. 1939

The fishes of the Ottawa region. R. Ontario Mus. Zool. Contrib. 15. 43 pp.

Gives information on where the muskellunge could be found in the Ottawa vicinity. Mentions where it had previously been reported in this area. Ontario and Quebec commercial catch records are discussed.

Dymond, J. R. 1947

A list of the freshwater fishes of Canada east of the Rocky Mountains with keys. R. Ontario Mus. Zool. Misc. Publ. 1. 36 pp.

Gives distribution of muskellunge and names three subspecies.

Dymond, J. R. 1964 a

A history of ichthyology in Canada. Copeia 1964(1): 2-33.

Refers to some of the work done on muskellunge in Canada.

Dymond, J. R. 1964 b

The fisheries of the Great Lakes. Chap. 7, pp. 73-92. In Dymond, J. R., ed. Fish and Wildlife a memorial to W. J. K. Harkness. Toronto, Longmans Canada. 214 pp.

Since 1898 it has not been legal to catch the muskellunge commercially.

Dymond, J. R., J. L. Hart and A. L. Pritchard 1929

The fishes of the Canadian waters of Lake Ontario. Univ. Toronto Stud. Biol. Ser. 33, Publ. Ontario Fish. Res. Lab. 37: 1-35.

Esox masquinongy was taken in Hay Bay of the Bay of Quinte area near Belleville during the study and said to be found in the Trent River and Kawartha Lakes and also the Thousand Island area of the St. Lawrence.

Eckroat, L. R. 1974

Interspecific comparisons of lens proteins of Esocidae. Copeia 1974(4): 977-978.

Lens protein analysis of six species of Esox showed that the larger species have practically identical patterns, and pike and muskellunge have an extra band in the most cathodal region as compared to the pickerel electrophorograms. Photographs of the electrophoretic patterns accompany the discussion.

Eddy, S. 1940

Do muskellunge and pickerel interbreed? Prog. Fish-Cult. 48: 25-28.

Describes rearing of muskellunge $\times$ pickerel hybrids. Growth, feeding, and habits of the hybrid fry are discussed.

Eddy, S. 1941

Muskellunge and muskie hybrids. Minnesota Conserv. Bull. 3(14): 41-44.

Eddy, S. 1944

Hybridization between northern pike (Esox lucius) and muskellunge (Esox masquinongy). Proc. Minnesota Acad. Sci. 12: 38-43. 
Eddy, S. 1957

How to know the freshwater fishes. Pictured-keys for identifying all of the freshwater fishes of the United States and also including a number of marine species which often enter freshwater. Dubuque, lowa, W. C. Brown. 253 pp.

ldentification key, short description, and black and white drawing.

Eddy, S. and K. D. Carlander 1939

Growth of Minnesota fishes. Minnesota Conserv. Bull. 69: 8-10.

Eddy, S. and K. D. Carlander 1942

Growth rates studies of Minnesota fish. Minnesota Dep. Conserv. Bur. Fish. Res. Invest. Rep. 28. 64 pp. Mimeograph.

Eddy, S. and A. C. Hodson 1951

Taxonomic keys to the common animals of the north central States exclusive of the parasitic worms, insects and birds. Minneapolis, Minnesota, Burgess. $123 \mathrm{pp}$.

ldentification key.

Eddy, S. and T. Surber 1960

Northern fishes with special reference to the upper Mississippi Valley. Rev. ed. Massachusetts, C. T. Branford. $276 \mathrm{pp}$.

Note on the northem muskellunge. Esox masquinongy immaculatus, gives description, location where found, size, food, habits, life history, hybrids, artificial propagation, and angling. (pp. 189-191)

Eddy, S., R. C. Tasker and J. C. Underhill 1972

Fishes of the Red River, Rainy River, and Lake of the Woods, Minnesota, with comments on the distribution of species in the Nelson River drainage. Univ. Minnesota, Bell Mus. Nat. Hist. Occas. Pap. 11. 24 pp.

"Esox masquinongy Mitchill, the muskellunge, is present in Lake of the Woods and the Winnipeg River drainage system, but it has never been found in the Red River drainage."

Eddy, S. and J. C. Underhill 1972

Northern fishes with special reference to the Upper Mississippi Valley. 3rd ed. Univ. Minnesota Press.

Edson, O. 1909

The fish that gave us the name Chautauqua. Chautauqua Mag., July: 186-214.

Elliot, C. 1957

Daddy's jack. Outdoor Life 120(6): 76-77, 106-108.

Ellis, M. 1953

Queen of the muskie hunters. Field Stream, September: 42-43, 68, 133.

Ellis, M. 1957

Long legged pike. Outdoor Life 120(2): 36-37, 71-72.

Ellis, M. 1960

More and more muskies. Field Stream, November: 58-59, 112-113, 118.

Ellis, M. 1964

Muskie myths exploded. Field Stream, July: 50-51, 89-90.

Ellsworth, F. B. 1915

A prize muskie of Lac Vieux Desert. Field Stream, September: 498-501. 
Elson, P. F. 1940

Rearing maskinonge in a protected area. Ontario Dep. Game Fish., Monthly Bull., March/ April: 7-9.

Limited success was achieved in rearing hatchery muskellunge to an advanced stage in a selected natural area.

Elson, P. F. 1941

Rearing maskinonge in a protected area. Trans. Am. Fish. Soc. (1940) 70: 421-429.

A method of rearing muskellunge to an advanced fingerling stage was investigated. Fry were planted in a favourable natural habitat and predators were removed as much as possible. A yield of 0.8 fingerling for 1,000 fry planted was obtained.

Emery, A. R. 1974

Life in the water. Part 3, pp. 56-98. In Glossop, J., ed. The nature of fish. The lllustrated Natural History of Canada. Toronto, Natural Science Canada. 160 pp.

Colour drawing of the muskellunge. Short caption describing the pike and the muskellunge. (pp. 76-77)

Engstrom-Heg, R. 1971

Experimental fish control. Development of cold branding as a long-term mark, especially on large-scaled fish. New York Div. Fish Game, D-J Proj. F-9-R-18, wk. pl. 2, Job B, Fin. 3 pp.

Engstrom-Heg, R. 1972

Experimental fish control. Development of cold branding as a long-term mark, especially on large-scaled fish. New York Div. Fish Game, D-J Proj. F-9-R-19, wk. pl. 2, Job B. 5 pp.

Erickson, J. 1961

Muskellunge stocking evaluation in Deer Creek Reservoir, Stark County, Ohio. Ohio Dep. Nat. Resour. Div. Wildl. Tech. Rep. Publ. W-314. 5 pp.

Data given on size and age of muskellunge stocked in Deer Creek Reservoir. Spot creel and test netting were used to evaluate results of stocking.

Erickson, J. 1966

Fish inventory and evaluation. Deer Creek Lake management report, 1954-1962. Ohio Div. Wildl., D-J Proj. F-29-R-5, Job 7, PT2: 70-115.

Erickson, J. 1969

Fish inventory and evaluation. Management consultation and experimental design. Ohio Div. Wild1., D-J Proj. F-29-R-7, Job 12. 10 pp.

Evanoff, V., ed. 1962

Fishing secrets of the experts. Garden City, New York, Doubleday. 288 pp.

Evermann, B. W. 1902

Pike, pickerel, mascalonge. For. Stream 59(10): 193.

This account attempts to correct misconceptions that might have arisen as a result of previous articles on this subject. A key for identification of the species is included.

Evermann, B. W. 1906

The Chautauqua muskallunge. For. Stream, November: 828.

Evermann, B. W. and E. L. Goldsborough 1901

Notes on the fishes and mollusks of Lake Chautauqua, New York. New York For. Fish Game Comm. 6th Annu. Rep. (1900): 357-366.

This is an account on the Chautauqua muskellunge, Lucius ohiensis, which at that time was ranked as a separate species from the Great Lakes form. The following topics are discussed: description of the species, distribution, culture in Lake Chautauqua (including a table giving planting statistics for 1890-1898), angling, bait to use, and attributes as a food fish. 
Evermann, B. W. and E. L. Goldsborough 1902

Notes on the fishes and mollusks of Lake Chautauqua, New York. U.S. Comm. Fish Fish. Rep. (1901): 169-175.

The Chautauqua nuskellunge, then named Lucius ohiensis (Kirtland), is considered one of the most important game and commercial fish species in Chautauqua Lake and as such is discussed in sonre detail. The following are considered: markings and coloration, first description of the species, occurrence, propagation including first successful egg hatching, table giving fry stocking data 1890-1898, attributes as a sport fish, methods of capture, attributes as a food fish, and voracity.

Evermann, B. W. and E. L. Goldsborough 1907

A check list of the freshwater fishes of Canada. Proc. Biol. Soc. Washington 20: 89-120.

Ewbank, E. L. 1916

Muskallonge on the French Broad. For. Stream. August: 1090, 1112.

Fallis, A. M. 1964

Parasites - our silent enemy. Chap. 10.pp. 121-140. In Dymond, J. R., ed. Fish and Wildlife a memorial to W. J. K. Harkness. Toronto, Longmans Canada. 214 pp.

Round cell sarcoma, a malignant tumor that occurs on the muskellunge, may be caused by a virus. Some species of Myxosporidia (Protozoa) occur on the gills and in the mouths of muskellunge.

Fantham, H. B., A. Potter and L. R. Richardson 1939

Some Myxosporidia found in certain freshwater fishes in Quebec Province, Canada. Parasitology $31(1): 1-77$.

Original description of Myxobolus dentium, a histozoic myxosporidian parasite from the tooth patches of a muskellunge.

Fedoruk, A. N. 1969

Checklist of and key to the freshwater fishes of Manitoba. Manitoba Dep. Mines Nat. Resour., Canada Land lnventory Proj. 98 pp.

Characteristics of the muskellunge are given in the key and exemplified in figure. (pp. 3, 84)

Fedoruk, A. N. 1971

Freshwater fishes of Manitoba: checklist and keys. Manitoba Dep. Mines Resour. Environ. Manage. $130 \mathrm{pp}$.

Characteristics of the muskellunge (said rarely to be found in Manitoba) are listed. There are also sketches showing markings and meristics. (pp. 5, 113, 115)

Ferguson, R. G. 1958

The preferred temperature of fish and their midsummer distribution in temperate lakes and streams. J. Fish. Res. Board Canada 15(4): 607-624.

Mentions the $24.0^{\circ} \mathrm{C}$ final temperature preferenda of muskellunge as found by Jackson and Price (MS 1949).

Fetterolf, C. M., Jr. 1957

Stocking as a management tool in Tennessee reservoirs. Proc. Southeastern Assoc. Game Fish Commr. 10: 275-284.

Fichter, G. S. 1963

Fishes. The Golden Bookshelf of Natural History, New York, Golden Press. 104 pp.

Popular account on the pike family with special reference to muskellunge. Small colour drawing. (pp. 31, 73)

Fine, I. and E. Werner 1960

Economic significance of fishing in Wisconsin. Wisconsin Vacation Recreation Paper. Univ. Wisconsin School Commerce 1(10). 
Fischthal, J. H. 1947

Parasites of northwest Wisconsin fishes. I. The 1944 survey. Trans. Wisconsin Acad. Sci. Arts Lett. 37: 157-220.

Table lists parasites found in the muskellunge examined and indicates their frequency. There is a brief note that describes where in the infected fish the parasites were found.

Fischthal, J. H. 1950

Parasites of northwest Wisconsin fishes. II. The 1945 survey. Trans. Wisconsin Acad. Sci. Arts Lett. 40: 87-113.

Note indicates the number of specimens infected with each parasite. The muskellunge examined from Teal Lake was infected with Philometra sp., Triaenophorus nodulosus, and Macroderoides spiniferus. One or another of the six muskellunge examined from Yellow River was infected with one or more of: Contracaecum brachyurum glochidia, Leptorhynchoides thecatus, Neoechinorhynchus tenellus, Phyllodistomum sp., Pomphorhynchus bulbocolli, Spiroxys sp., Proteocephalus pingius, and Trichodina sp.

Fischthal, J. H. 1957

Cestrahelmins laruei N. G. n. sp., a digenetic trematode from the muskellunge Esox $m$. masquinongy Mitchill. J. Parasitol. 43(4): 484-487.

During a parasite survey of northwest Wisconsin fishes Fischthal (1950) recorded a moderate infection (12 worms) of Macroderoides spiniferus occurring in the small intestine of the one muskellunge collected on August 1, 1945, from Teal Lake, Sawyer County. A re-study of this material through serial cross and frontal sections indicated that the previous identification was erroneous and that a new genus and species, Cestrahelmins lariei, of uncertain familial relationship is represented. Generic and specific descriptions are given. (Author's abstract)

Fish, M. P. 1932

Contributions to the early life histories of sixty-two species of fishes from Lake Erie and its tributary waters. U.S. Dep. Commerce Bur. Fish. Bull. 47(10): 293-398.

Information is given on the early life history of muskellunge under the following headings: record of capture, description - adults, egg, $11.6 \mathrm{~mm}, 13.9 \mathrm{~mm}, 14.0 \mathrm{~mm}, 15.0 \mathrm{~mm}$, $33.8 \mathrm{~mm}$ stages (drawing of each stage) - and breeding.

Flower, S. S. 1925

Contributions to our knowledge of the duration of life in vertebrate animals. 1. Fishes. Proc. Zool. Soc. London (1925): 247-268.

Report of a muskellunge's living ten years in an aquarium. (Mellen, 1919)

Foote, H. G. 1923

Mosquito, moose and mascallonge. For. Stream, October: 554-555, 578-584.

Foote, H. G. 1924

Mosquito, moose and mascallonge. For. Stream, March-April-May-June-July: 146-147, $183-185,200-201,242,245,266-268,311-312,330,331,375-376,426-428$.

Forbes, S. A. 1884

A catalogue of the nati a fishes of Illinois. Illinois Fish Comm. Rep.: 60-89.

Esox nobilior reported from Lake Michigan. (p. 71)

Forbes, S. A. and R. E. Richardson 1920

The fishes of Illinois. 2nd ed. Illinois Nat. Hist. Surv. Dep. Regist. Educ. 357 pp.

Brief note on Esox masquinongy. (p. 209)

Ford, C. 1959

The Judges tangled web. Field Stream, July: 12-13, 17. 
Forelle, F. 1857

On the classification of fishes. With particular reference to the fishes of Canada. Article 43, pp. 275-283. In Billings, E. The Canadian Naturalist and Geologist. Vol. I. Montreal, J. Lovell. 480 pp.

Referred to the muskellunge as Esox estor and said the Ojibwa called it maskinongé, from which the name was corrupted into mascalonge.

Forney, J. L. 1969

Warm water fishery management in New York lakes and ponds. Production and behaviour of muskellunge in a controlled marsh. New York Div. Fish Game, D-J Proj. F-17-R-13, wk pl. 2, Job B, Fin. 5 pp.

Fowler, H. W. 1918

A review of the fishes described in Cope's partial catalogue of the cold-blooded vertebrata of Michigan. Univ. Michigan. Mus. Zool. Occas. Pap. 60. 51 pp.

Detailed taxonomic description of a poor specimen of muskellunge taken from Saginaw Bay.

Fox, A. L. 1958

Muskellunge experiment underway. North Dakota Outdoors 21(2): 10-13.

Fox, C. K. 1968

The muskie revolution. Outdoor Life 14I(3): 39-41, 114-119.

Fox, C. K. 1970

Muskies near millions. Sports Afield, April: 56-57, 102, 104-106.

Friedrich, G. W. 1933

A catalog of the fishes of central Minnesota. Copeia 1933(1): 27-30.

Gives location where Esox masquinongy immaculatus (Garrard) has been found in Minnesota.

Fry, F. E. J. and V. B. Chapman 1948

The lake trout fishery in Algonquin Park from 1936 to 1945. Trans. Am. Fish. Soc. (1945) 75: 19-35.

Esox masquinongy has been captured in a limited region in the northwest comer of Algonquin Park.

Fry, F., J.-P. Cuerrier et G. Préfontaine 1941

Première croissance du maskinongé dans le lac Saint-Louis en 1941. Appendix 7, pp. 170175. Québec Minist. Chasse Pêche Rapp. Stn. Biol. Montréal et Stn. Biol. Parc Laurentides (1941), Fascicule 2.

Data for eight specimens taken from Lac Saint-Louis, Quebec, given as follows: place captured, date, length, habitat, depth. Some extrapolation of data indicates hypothetical growth.

Fry, F., G. Préfontaine et J.-P. Cuerrier 1941

Recensement de la pêche sportive dans le lac Saint-Louis. Appendix 4,pp. 120-132. Québec Minist. Chasse Pêche, Rapp. Stn. Biol. Montréal et Stn. Biol. Parc Laurentides (1941), Fascicule I.

Creel census of fishery of Lac Saint-Louis giving number of each species caught during June, July, and August, 1941, and number per 100 hours of fishing.

Fuelsch, D. 1963

Musky fishing in the south. Don Fuelsch's Southern Anglers Hunters Guide.

Fuller, B. 1969 a

Tangle with the tiger. Fur-Fish-Game, July: 10-11, 33-36. 
Fuller, B. 1969 b

Best muskie fishing by a dam site. Fur-Fish-Game, October: 10-11, 39-40.

Fuller, B. 1970

New waters for big musky. Fish. Hunting Guide, June: 37, 57.

Fuller, B. 1974

Muskie El Dorado. Fur-Fish-Game, May: 10-11, 28.

Gabrielson, I. N., ed. 1963

The fisherman's encyclopedia. 2nd ed. Harrisburg, Pennsylvania, Stackpole. 698 pp.

General information on the muskellunge, including range, colour, distinguishing characteristics, size, food, and habits.

Galat, D. L. 1972

Preparing teleost embryos for study. Prog. Fish-Cult. 34(1): 43-48.

Preserving, staining, and clearing techniques found useful in preparing muskellunge embryos for developmental studies are explained. Summarizes techniques used by others.

Galat, D. L. 1973

Normal embryonic development of the muskellunge (Esox masquinongy). Trans. Am. Fish. Soc. 102(2): 384-391.

This paper documents the gross normal embryonic development of the muskellunge, Esox masquinongy, from fertilization until hatching with preserved specimens. Eggs were incubated at $13^{\circ} \mathrm{C}$ and samples taken every hour during the first 20 hours of incubation and every 6 hours thereafter until hatching on the 13th day. Line drawings illustrate development. (Author's abstract)

Galat, D. L. and A. W. Eipper 1969

Preliminary investigation on the effects of incubation temperature on the survival of muskellunge (Esox masquinongy) embryos. Cornell Univ., New York Coop. Fish. Unit. 18 pp. Mimeograph.

Fertilized eggs from two hatcheries were incubated at a series of temperatures. Although there were serious experimental problems, a reasonable correlation was discovered between time to hatch and development, mortality, and incubation temperature. Several graphs illustrate results. An appendix gives complete specifications for equipment and methods used for the experiment.

Galat, D. L. and A. W. Eipper 1975

Presence of food organisms in the prolarval environment as a factor in the growth and mortality of larval muskellunge (Esox masquinongy). Trans. Am. Fish. Soc. 104(2): 338-341.

Three different feeding programmes were used to assess the need for zooplankton in the environment of prolarval muskellunge.

Neither mortalities nor dry weights differed significantly between treatments, indicating that presence of food organisms prior to swim-up was not critical to survival or growth of muskellunge larvae under the conditions of this experiment.

Gall, J. 1973

Ohio muskellunge (Esox masquinongy ohioensis) stocking in Piedmont Lake: progress report. Ohio Dep. Nat. Resour. Div. Wildl. In Serv. Note 223. 5 pp. Mimeograph.

Galligan, J. P. 1962

Depth distribution of lake trout and associated species in Cayuga Lake, New York. New York Fish Game J. 9(1): 44-68. 
Gammon, J. R. 1960

The effects of maskinonge stocking on the resident fish populations of two dystrophic lakes. Univ. Wisconsin Dep. Zool., 22nd Midwest Wildl. Conf. I p. Mimeograph.

Outlines a study in which muskellunge were stocked in two lakes and studied for four years. Populations of largemouth bass and perch, which had previously been estimated, were greatly reduced, while smallmouth bass populations increased. Refer to Gammon and Hasler (1965).

Gammon, J. R. MS 1961

Contributions to the biology of the muskellunge. Univ. Wisconsin, Ph.D. thesis. $156 \mathrm{pp}$.

Two lakes were stocked with Esox masquinongy immaculatus.

Gammon, J. R. 1963

Conversion of food in young muskellunge. Trans. Am. Fish. Soc. 92(2): 183-184.

A study was conducted on muskellunge in aquaria to determine prey conversion in several different time periods. All food offered was weighed, and for each aquarium the following were determined: average total weight gained, per cent body weight consumed daily, and a conversion ratio.

Gammon, J. R. 1965

Device for collecting eggs of muskellunge, northern pike, and other scatter-spawning species. Prog. Fish-Cult. 27(1): 78.

Briefly describes how to construct a rectangular tray that can be used to collect naturallyspawned eggs of muskellunge.

\section{Gammon, J. and A. D. Hasler 1961}

A predator-prey interaction: the effect of muskellunge on the resident fish populations of two big lakes. Purdue Univ., Proc. Am. Soc. Limnol. Oceanogr. Am. Inst. Biol. Sci., August 26-31, Paper 354.

Gammon, J. R. and A. D. Hasler 1965

Predation by introduced muskellunge on perch and bass, 1: years 1-5. Trans. Wisconsin Acad. Sci. Arts Lett. 54: 249-272.

Two small Wisconsin lakes containing perch and bass were stocked with young muskellunge and the changes in population density, growth rate, and length-weight relationship were measured. The events that followed the introduction of the predator are discussed.

Gardner, K. 1971

Minnesota's many muskies. World, July/August: $28-29,36,58$.

Garland, C. 1973

Summary of musky egg collection at Rocky Fork Lake 1965-1973. Ohio Dep. Nat. Resour. Div. Wildl. In Serv. Note 230. 4 pp. Mimeograph.

Gerking, S. R. and K. F. Lagler 1945

Investigations of Indiana lakes and streams. Indiana Dep. Conserv. Rep. 3. 165 pp.

Germain, U. E. 1919

That grand daddy. Field Stream, October: 566-568, 622-625.

Gibbs, J. 1974

The tiger is waiting. Outdoor Life 154(3): 92-93, 134-136.

Gibson, M. B. and J. W. MacPherson MS 1954

Esox lucius $\times$ Esox masquinongy hybrids. Univ. Toronto Dep. Zool. Ontario Fish. Res. Lab. Rep. 3 pp. Manuscript. 
Gibson, R. J. and E. J. Schindler 1969

"Borrow pits" as rearing ponds for muskellunge and walleye. Manitoba Dep. Mines Nat. Resour. Fish. Branch Manuscript Rep. 69-5.37 pp.

Not available for public distribution.

Seventeen "borrow pits" were used as experimental rearing ponds for young muskellunge and walleye. Fish were stocked in June and removed in the autumn. Survival rates were calculated and features of ponds that gave the best recovery are discussed.

Gilfillan, M. C. 1960

Black swamp country. Ohio Conserv. Bull. 24(8): 18-21.

Girard, C. 1854

Observations on the American species of the genus Esox. Proc. Acad. Nat. Sci. Philadelphia (1852-1853) 6: 386.

Describes and compares the various members of the pike family.

Gleason, J. B. 1962

A sucker for muskies. Sports Afield, June: 68-71, 114-115.

Gleason, J. B. 1966

Muskies I have known. Fur-Fish-Game, May: 5-7.

Glover, C. R. 1960

The musky program. Pennsylvania Angler 29(6).

Godfrey, J., Jr. 1945

Muskies unlimited. Outdoors 13(8): 10-11, 36.

Considered that there were at least three species: Esox masquinongy, E. ohioensis, and E. immaculatus, and possibly a fourth, Esox amentus. The fish described as Esox amentus was more probably a muskellunge $\times$ pike hybrid.

Goode, G. B. 1879

Catalogue of the collection to illustrate the animal resources and the fisheries of the United States. List of animals of North America beneficial or injurious to man. U.S. Natl. Mus. Bull. 14: $1-70$.

Cast and photographs of Esox nobilior Thompson were exhibited at an exhibition in 1876.

Goode, G. B. 1884

The food fisheries of the United States. Part 3, pp. 163-682. In Goode, G. B. et al., eds. The fisheries and fishery industries of the United States. Sect. 1. Natural history of useful aquatic animals. Washington, Government Printing Office.

Goode, G. B. 1926

American fishes. A popular treatise upon the game and food fishes of North America with especial reference to habits and methods of capture. Boston, L. C. Page. $562 \mathrm{pp}$.

Short descriptive note on the muskellunge.

Goode, G. B. and Associates, eds. 1884

Atlas of two hundred and seventy-seven plates. In Goode. G. B. et al., eds. The fisheries and fishery industries of the United States. Sect. 1. Natural history of useful aquatic animals. Washington, Government Printing Office.

Black and white drawing of a muskellunge specimen.

Gordon, S. W. 1955

How to fish from top to bottom. Harrisburg, Pennsylvania, Stackpole. 384 pp. 
Gorham, C. 1974

Operation musky - projects are designed to find out more about Kentucky's Trophy fish. Kentucky Conserv. Bull.

Goth, L. A. 1974

Tricks that took 241 muskies. Sports Afield Fish. Annu.: 88-92.

Graff, D. R. 1968

The successful feeding of a dry diet to esocids. Prog. Fish-Cult. 30(3): 152.

Brief note mentions tests to determine if esocids would accept dry diets. Very poor results were obtained with muskellunge but Esox lucius $\times$ Esox masquinongy hybrid readily accepted a dry diet.

Graff, D. R. MS 1972

Observations on interactions between juveniles of Esox lucius and Esox masquinongy. Pennsylvania State Univ. Dep. Biol., M. Ed. thesis. $72 \mathrm{pp}$.

A study of the competition between young pike and young muskellunge includes: behaviour, feeding, postures (threat, alarm, submission), and relative survival.

Graff, D. R. and L. Sorenson 1970

Successful feeding of a dry diet to esocids. Prog. Fish-Cult. 32(1): 31-35.

Mortalities were extremely high when a hatchery diet was fed to esocids, except for commercial trout food. Dry trout food was readily accepted by northern pike and the pike $x$ muskellunge hybrid and partly accepted by muskellunge. Feeding experiment is described.

Graham, F. H. 1919

Fighting the fresh water tiger. For. Stream, September: 468-469.

Grahame, A. 1953

N. Y. S. muskalonge. Outdoor Life 112(2): 38-39, 70-71.

Gravel, Y. et J. Guindon MS 1962

Projet de pisciculture pour l'élevage du maskinongé, Parc Dollard-des-Ormeaux. Québec Minist. Chasse Pêch. Serv. Aménagement Faune. 13 pp. Manuscrit.

An experiment was conducted to determine suitability of Carillon, Quebec, for a fish culture station. Mortality in the summer was considered to be due to high water temperature, which seemed to be accompanied by increased disease and parasitism.

Gravel, Y. et J. Guindon 1965

Station piscicole expérimentale pour l'élevage du maskinongé, parc Dollard-des-Ormeaux, Carillon, comté Argenteuil. Québec Minist. Tourisme Chasse Pêche Serv. Faune Rapp. 5: 261-266.

Greeley, J. R. 1929

Fishes of the Erie-Niagara watershed. Sect. 6, pp. 150-188. In A biological survey of the Erie-Niagara system. New York Conserv. Dep. Suppl. 18th Annu. Rep. (1928). 244 pp.

The distribution of the muskellunge in the area is given in a chart. There is a paragraph note on the species in the annotated list. (pp. 165, 175)

\section{Greeley, J. R. 1938}

Fishes of the area with annotated list. Sect. 2, pp. 48-60. In a biological survey of the Allegheny and Chemung watersheds. New York Conserv. Dep. Suppl. 27th Annu. Rep. (1937), Biol. Surv. 12. 287 pp.

Presents results of growth-rate studies on the muskellunge. Growth data for Chautauqua Lake muskellunge and age-weight composition of anglers' catch of muskellunge are given in tables and discussed. Management recommendations based on results of study are proposed.

Short note in the annotated list gives lakes where muskellunge found in New York. Colour illustration. 
Greeley, J. R. and S. C. Bishop 1932

Fishes of the area with annotated list. Sect. 2, pp. 54-92. In A biological survey of the Oswegatchie and Black River systems. New York Conserv. Dep. Suppl. 21 st Annu. Rep. (1931), Biol. Surv. 6. 344 pp.

Short note on muskellunge in annotated list. Muskellunge included in chart of fish distribution of the watershed.

Greeley, J. R. and C. W. Greene 1931

Fishes of the area with annotated list. Sect. 2, pp. 44-94. In A biological survey of the St. Lawrence watershed. New York Conserv. Dep. Suppl. 20th Annu. Rep. (1930), Biol. Surv. 5. $261 \mathrm{pp}$.

Brief note on the St. Lawrence muskellunge in the annotated list. Muskellunge also included in chart showing fish distribution of the St. Lawrence watershed.

Green, D. M., Jr. 1974

Fisheries investigations of Canadarago Lake. Creel census of Canadarago Lake. U.S. Fish Wildl. Serv., New York Dep. Environ. Conserv., Cornell Univ., D-J Proj. F-29-R-1, Job 2a. $15 \mathrm{pp}$.

The muskellunge is occasionally found in Canadarago Lake.

Green, D. M., Jr. 1975 a

Fisheries investigation of Canadarago Lake. Response of fish populations to control of nutrients in a eutrophic lake. New York Dep. Environ. Conserv., D-J Proj. F-2-R-2, Study 1. 66 pp.

Green, D. M., Jr. 1975 b

Fisheries investigation of Canadarago Lake. Changes in fishing effort and catch on Canadarago Lake. New York Dep. Environ. Conserv., D-J Proj. F-2-R-2, Study 2: 67-79.

Greene, C. W. MS 1934

The distribution of Wisconsin fishes. Univ. Michigan, Ph.D. thesis. 306 pp.

The distribution pattern of Esox masquinongy masquinongy and Esox masquinongy immaculatus is discussed.

Greene, C. W. 1935

The distribution of Wisconsin fishes. Wisconsin Conserv. Comm. 235 pp.

The distribution of Esox masquinongy is discussed.

Gregory, M. 1971

Missouri's new "tiger fish". Fish. Hunting Guide, May: 50, 61 .

Gregory, W. K. 1933

Fish skulls: a study of the evolution of natural mechanisms. Trans. Am. Philos. Soc. 23, Art. 2. $481 \mathrm{pp}$.

Muskellunge is used as the type example for the genus Esox. Discusses the dominant features of the skull, but may be somewhat in error in some respects. There are drawings of the side view and top view of the skull. (pp. 214-216)

Grey, J. 1974

Propagation of muskellunge 1968 through 1974. Morehead, Kentucky, Proc. 6th Interstate Muskellunge Workshop, September 25-26: 93-94. Mimeograph.

Muskellunge were introduced to Virginia in 1963. Note outlines pond spawning of muskellunge to produce stock.

Grosvenor, M. B., ed. 1969

The wondrous world of fishes. Natl. Geogr. Mag. 373 pp.

Accompanying a brief descriptive note on the muskellunge is a colour drawing. (p. 274) 
Guillet, E. C. 1963

Early life in Upper Canada. Univ. Toronto Press. $782 \mathrm{pp}$.

Refers to the writings of early settlers in which mention is made of the muskellunge under various spellings of the common name.

Guindon, J. 1965

L'élevage du maskinongé en Ontario. Québec Minist. Chasse Pêch. J. Bord 3(65): 551-552.

The procedure used at Deer Lake Hatchery, Ontario, to rear muskellunge suitable for stocking is described.

Günther, A. 1866

Catalogue of the Physostomi, containing the families Salmonidae, Percopsidae, Galaxidae. Mormyridae, Gymnarchidae, Esocidae, Umbridae, Scombresocidae, Cyprinodontidae, in the collection of the British Museum. Vol. 6. London. $368 \mathrm{pp}$.

Description of Esox estor referred to as the muskellunge and a discussion of the use of the scientific names $E$. estor, $E$. lucius and $E$. nobilior by various authors.

Günther, A. 1880

An introduction to the study of fishes. Edinburgh, A. and C. Black. 720 pp.

The muskellunge (Esox estor) of the Great Lakes is said to attain the same large size as the common pike.

Hacker, V. A. 1966

An analysis of the muskellunge fishery of Little Green Lake, Green Lake County, Wisconsin 1957-65. Wisconsin Conserv. Dep. Fish Manage. Div. Manage. Rep. 4. 17 pp.

Muskellunge were stocked in Little Green Lake, Green Lake County, Wisconsin, after the existing fish population was removed by chemical treatment in 1956. Tagging studies and voluntary creel census retums are discussed.

Hacker, V. A. 1967

Soup bowl to fish bowl. Wisconsin Conserv. Bull., July/August.

Hacker, V. A. 1973

The results of a ten year voluntary muskellunge creel census at Little Green Lake, Green Lake County. Wisconsin, 1963-1972. Wisconsin Dep. Nat. Resour. Fish Manage. Rep. 58. 14 pp.

Following treatment of Little Green Lake, Wisconsin, muskellunge were introduced. All stocked after 1960 were marked. From 1963 to 1972 a voluntary creel census was taken and returns recorded.

Halkett, A. 1913

Check list of the fishes of the Dominion of Canada and Newfoundland. Ottawa, C. H. Parmelee, King's Printer. 138 pp.

The scientific name applied to the muskellunge in the scheme of classification was Lucius masquinongy: Noted distribution. (pp. 20,69)

Hall, T. 1951

Muskies at Minocqua. Sports Afield, May: 34-35.

Hallock, C. 1877

The sportsman's gazetteer and general guide. The game animals, birds and fishes of North America; their habits and various methods of capture. New York, For. Stream Publ. 688 pp.

Halstadt, W. 1957

My most thrilling fishing experience. Fish. World, June: 20.

Hamer, C. 1973

Muskellunge: heavyweight champ of the north. Fins Feathers, August: 6-7. 
Hamer, C. 1974

Tips that take big muskies. Fins Feathers, August: 22-24, 28.

Hanson, A. 1949

Prize musky and walleye waters. Wisconsin Conserv. Bull., July: 7-10.

Harbour, D. 1972

Crafty tactics for trophy muskies. Sports Afield, May: 49-51, 143-144, 146-147.

Harding, J. C. 1915

A prize musky from Wisconsin. Field Stream, December: 848

Harkness, W. J. K. 1934

The maskinonge in Ontario. Rod Gun Canada 35(10).

Harkness, W. J. K. 1936 a

Lake Nipissing rates fourth among Ontario's small lakes. Article 3. Biological study of Lake Nipissing. North Bay Nugget, February 7.

"Maskinonge are to be found in limited numbers in some of the shallow, somewhat weedy areas of the lake."

Harkness, W. J. K. 1936 b

Commercial fishing effects studied in Lake Nipissing. Article 4. Biological study of Lake Nipissing. North Bay Nugget, February 14.

Certain game species such as the muskellunge were suffering from extensive commercial fishing. Includes a commercial fishing table giving total pounds of various fish including $E$. masquinongy caught each year from 1885 to 1934 .

Harkness, W. J. K. $1936 \mathrm{c}$

Describes culture of fish under conservation scheme. Article 5. Biological study of Lake Nipissing. North Bay Nugget, February 21.

In a general discussion on the principles of fish culture, the author uses the example of a type of lake that would quite likely include the muskellunge.

Harkness, W. J. K. $1936 \mathrm{~d}$

Sanctuaries are necessary to preserve Nipissing musky. Article 12. Biological study of Lake Nipissing. North Bay Nugget, April 9.

Reasons for scarcity of muskellunge in Lake Nipissing are given. General notes on biology, distribution, and habitat, and suggestions for maintaining the population follow.

Harkness, W. J. K. 1936 e

Nipissing's pike, maskinonge are observed by biologist. Article 13. Biological study of Lake Nipissing. North Bay Nugget, April 17.

Information is given on life history and biology. Primarily discusses the pike but compares it frequently with the muskellunge. Includes black and white drawings of both pike and muskellunge.

Harkness, W. J. K. $1936 \mathrm{f}$

Protect fishery resources to sustain tourist trade. Article 26. Biological study of Lake Nipissing. North Bay Nugget, July 17.

A daily limit of two muskellunge was considered liberal yet moderate.

Harkness, W. J. K. 1945

Rate of growth of game fish for fish and wildlife management. Univ. Toronto Dep. Zool. 6 pp. Mimeograph.

Contains a table that gives age and corresponding length and weight of muskellunge. 
Harkness, W. J. K. and J. R. Dymond 1936 a

Find definite relationship among fish of every stream. Article 20. Biological study of Lake Nipissing. North Bay Nugget, June 5.

List of fishes found in Lake Nipissing includes muskellunge, Esox masquinongy:

Harkness, W. J. K. and J. R. Dymond $1936 \mathrm{~b}$

Checklist of the fishes of Lake Nipissing. Article 20. Biological study of Lake Nipissing. North Bay Nugget. June 5.

Esox masquinongy listed in checklist.

Harkness, W. J. K. and F. E. J. Fry 1942

Game fish management in Algonquin Park lakes. Trans. North Am. Wildl. Conf. (1942) 7: $398-404$.

Describes location of Esox masquinongy in Algonquin Park.

Harkness, W. J. K. and R. R. Langford 1936

Lake Nipissing is limited in production of game fish. Article 2. Biological study of Lake Nipissing. North Bay Nugget, January 31.

Explains food chain in lake. Carnivorous fish such as the nuskellunge are at the "top" of the food chain but ultimately depend on the nutrients entering the lake, which the plankton, at the "bottom" of the food chain, feed on.

Harlan, J. R. and E. B. Speaker 1956

lowa fish and fishing. 3rd ed. lowa Conserv. Comm. 377 pp.

Only a couple of muskellunge have been officially reported from Ohio. There is a short note giving the following information: common names, description, food habits, life history, and angling.

Hartman, L. 1962

World record spin catch - musky. Fur-Fish-Game, May: 9-11, 32-33.

Hartman, L. 1967

Len Hartman: a champion's musky secrets. Sports Review's Complete Fish.: 72-74.

Hasler, A. D., R. K. Meyer and H. M. Field 1940

The use of hormones for the conservation of muskellunge, Esox masquinongy immaculatus Garrard. Copeia 1940(1): 43-46.

An experiment was undertaken to induce spawning by injecting with carp pituitary glands. In section 1 of a pond, where fish had been injected with pituitary glands, all had spawned and a normal hatch was reported. In section 2, the same number of fish had the same treatment but were not injected (control). These did not spawn.

Table 1 shows spawning results from muskellunge injected with carp pituitary glands. Injection with carp pituitary does overcome resistance to spawning in captive muskellunge.

Hassan, K. C. and J. R. Spotila 1976

The effect of acclimation on the temperature tolerance of young muskellunge fry. pp. 136-140. In McFarlane, R. and G. Esch. eds. Thermal ecology. Vol. 2. ERDA Symposium Series (Conf.-750425). 404 pp.

Hasse, J. J. MS 1976 a

A comparison of the St. Lawrence River muskellunge fishery to other muskellunge waters with a recommendation on regulation changes. New York Dep. Environ. Conserv. Rep. 10 pp. Manuscript.

Summarizes creel census results and compares time of capture, stomach contents, and regulations for muskellunge from other areas. 
Hasse, J. J. 1976 b

Bibliography of the muskellunge (Esox masquinongy). New York Dep. Environ. Conserv. 22 pp. Mimeograph.

Haver, P. 1962

My 3,000 muskies. Outdoor Life 130(2): 58-59, 109-113.

Haworth, P. L. 1910

The 'lunge of French River. Outing Mag., April: 18-27.

Hayden, C. A. 1904

The first muscallonge. Outing Mag., November: 164-165.

Hayes, J. 1965

Tionesta muskies. Sports Afield, June: 34-35, 96-98.

Hayes, J. 1967

Some like it cold. Field Stream, December: 46-47, 84-85.

Heacox, C. E. 1946

The Chautauqua Lake muskellunge: research and management applied to a sport fishery. Trans. 11 th North Am. Wildl. Conf.: 419-425.

The muskellunge population of Chautauqua Lake, New York, became greatly depleted owing to increased fishing pressure, improved angling methods, and a 24 -inch $(610 \mathrm{~mm})$ size limit. In 1941 a restoration programme was begun. It consisted of new restrictive regulations, renewed efforts of artificial propagation of muskellunge, and research. Data collected by creel census and spawn-taking operations during the five-year study indicated improvement in angler catch and a substantial increase in the muskellunge population.

Heacox, C. E. 1958

Record game fish of New York. New York Conserv. Dep. Inf. Leafl., April-May.

Included in a list of record game fish caught in New York to that date is an Esor masquinongy of 69 pounds, 15 ounces $(31.72 \mathrm{~kg})$ caught in the St. Lawrence River and an Esox masquinongy ohiensis of 51 pounds, 3 ounces $(23.22 \mathrm{~kg})$ caught in Chautauqua Lake.

Heacox, C. E. 1971

Comeback of a heavyweight. Outdoor Life 148(1): 46-49, 92, 94-95.

Hein, E. N. 1940

Wisconsin's fishing. Wisconsin Conserv. Bull. 5(10): 37-41.

Lists fish species stocked in each county.

Helm, J. M. 1960

Returns from muskellunge stocking. Wisconsin Conserv. Bull. 25(6): 9-10.

Summary of results of stocking High Lake and Fishtrap Lake ten years before 1950. The stocking appears to have been fairly successful in High Lake but unsuccessful in Fishtrap Lake, and possible explanations are given.

Henry, S. 1970 a

Home run for muskies. Fish. Hunting Guide, February: 8-9, 54.

Henry, S. 1970 b

Wisconsin's choice of the experts - Shell Lake. Fish. Hunting Guide, August: 8 .

Henshall, J. A. 1892

The mascalonge. pp. 191-199. In Perry, W. A. et al. American game fishes their habits, 
habitat, and peculiarities: how, when, and where to angle for them. Chicago, New York, Rand. McNally. 865 pp.

General discussion of the muskellunge.

Henshall, J. A. 1904

Mascalonge or maskinonge. For. Stream, March: 253.

Henshall, J. A. 1920

Dr. J. A. Henshall's autobiography. A record of many interesting trips to famous fishing waters in the United States, Canada and Cuba during the early eighties. For. Stream 90: $432-433,468-471$.

Henshall states that there is only one muskellunge despite some geographical differences. Colour and markings of the muskellunge are described.

Henshall, J. A. 1923

Bass, pike, perch and other game fishes of America. New ed. Cincinnati, Stewart and Kidd. $410 \mathrm{pp}$.

There is a several-page account on the muskellunge then given the scientific name Esox nobilior. Discusses problem of which scientific name and common name should be correctly given. Says the muskellunge from all areas be considered as one species.

Information is given on occurrence, distribution, description, food, habits, habitat, life history, and size, and there is a lengthy account on the muskellunge's characteristics as a game fish. Black and white drawings of the muskellunge in a natural situation. (pp. 120-127)

Herald, E. S. no date

Fishes of North America. Animal life of North America series. New York, Doubleday, Chanticleer Press. 254 pp.

A short note on the pikes (family Esocidae) includes a brief description of the family characteristics and features that identify the individual species such as muskellunge.

Herald, E. S. 1961

Living fishes of the world. Garden City, Doubleday, Chanticleer Press. 304 pp.

This account tells how to separate esocid species by scalation on cheek and opercle and size. There is a black and white illustration of the muskellunge.

Herbert, H. W. 1864

Frank Forester's fish and fishing of the United States and British provinces of North America. New and rev. ed. New York, W. A. Townsend. 359 pp.

The muskellunge is given the scientific name Esox estor in this book. Describes it in detail. There are two black and white drawings, one of the whole fish and one of the head. Remarks on an error in calling it Essex or Muscalinga in Mr. Brown's book "The American Angler's Manual". (pp. 150-153)

Herity, J. C. 1974

Marjory and the musky. Outdoor Canada 2(3): 13-14, 17.

An angler's account. Suggests that one should return muskellunge to the water after catching and perhaps measuring them. Small colour illustration.

Herity, J. C. 1975

To catch a muskie. Ontario Fisherman Hunter, July.

Hine, R. L., ed. 1961

Muskellunge studies. Wisconsin Conserv. Dep. Res. in Wisconsin (1960): 17-18.

Outlines the studies that have been carried out on muskellunge since 1955. Briefly discusses findings. 
Hinks, D. 1943

The fishes of Manitoba. Manitoba Dep. Mines Nat. Resour. 102 pp.

Key and brief note.

Hobbs, R. G. 1892

In the muscallunge country. For. Stream, February/March.

Hoeft, B. 1970

l'll tell you about muskies! Outdoor Life 146(2): 58-59, 118-120, 122.

Hoffman, G. L. 1967

Parasites of North American freshwater fishes. Berkeley, Univ. California Press. 486 pp.

This comprehensive treatise on North American freshwater fish parasites contains a fish and parasite checklist. Parasites found in Esox masquinongy and the hybrid, E. masquinongy $\times E$. lucius are listed. (pp. 366-368)

Holden, G. P. 1927

The art of casting. Part 4. For. Stream: 498-500.

Holder, C. F. no date

The game fishes of the world. London, Hodder and Stoughton. $411 \mathrm{pp}$.

Praises attributes of Esox masquinongy as a game fish, describes it, and gives some angling notes. Two other supposed species, Esox ohiensis and Esox immacularus, are described and the area where they are commonly found noted.

Hooper, F. F., J. E. Williams, M. H. Patriarche, F. Kent and J. C. Schneider 1964 Research and management of sport fisheries of Michigan. Development and evaluation of techniques for management of warm-water fishes. Status of lake and stream rehabilitation in the United States and Canada with recommendations for Michigan waters. Michigan Dep. Conserv., D-J Proj. F-27-R-2, wk. pl. 3, Job 3, SP. 56 pp.

Hough, E. 1890

Chicago and the west: some mascallonge experience. For. Stream, July: 3, 10, 17.

Hough, E. 1901

Angling in the middle west. Outing Mag., August: 495-500.

Hourston, A. S. MS 1949

A taxonomic study of the maskinonge in Canadian waters with additional reference to food and growth. Univ. Toronto, M. A. thesis. $163 \mathrm{pp}$.

Hourston, A. S. 1952

The food and growth of the maskinonge (Esox masquinongy Mitchill) in Canadian waters. J. Fish. Res. Board Canada 8(5): 347-368.

Muskellunge from three regions - (1) Lake of the Woods, (2) Kawartha Lakes and Georgian Bay, (3) St. Lawrence River - were studied. The stomach contents from 202 muskellunge were examined. Rate of growth and length-weight relationship were found to vary with locality and sex.

Hourston, A. S. 1955

A study of the variations in the maskinonge from three regions in Canada. R. Ontario Mus. Zool. Palaeontol. Contrib. 40. 13 pp.

A taxonomic study of the muskellunge from three regions of Ontario - (1) Western: Kenora, Northwest Ontario, (2) Central: Kawarthas, (3) Eastern: St. Lawrence - was done by comparing the morphometric and meristic characters. Some statistical analysis was done that is said to show significant differences between the three populations studied, and to indicate subspecific designations. 
Howard, S. H., ed. 1942

Muskellunge majestic. Rod Gun Canada 44: 28, 30.

Reported a new record (1942) for muskellunge from Lac Seul, Ontario, and hypothesized about how they noved into the Lake of the Woods area. Also noted distribution and best areas in Wisconsin and Ontario for muskellunge angling.

Hubbs, C. L. 1926

A check-list of the fishes of the Great Lakes and tributary waters, with nomenclatorial notes and analytical keys. Univ. Michigan Mus. Zool. Misc. Publ. 15. 77 pp.

Key to species of Esox includes Esox masquinongy. Short taxonomic note.

Hubbs, C. L. 1933

Data on muskellunge in Michigan. Univ. Michigan Inst. Fish. Res. Rep. 192. 3 pp.

Summary of distribution data for muskellunge in Michigan. Also describes distinguishing features and record sizes.

Hubbs, C. L. 1940

List of the fishes of Lake St. Clair and tributaries. Univ. Michigan Mus. Zool. 10 pp. Mineograph.

Lists the muskellunge, called Esox masquinongy masquinongy, with fishes of Lake St. Clair from specimens taken.

Hubbs, C. L. and D. E. S. Brown 1929

Materials for a distributional study of Ontario fishes. Trans. R. Can. Inst. 17(1): 1-56.

Presents results of fish collections made in the Great Lakes. Collection stations are described, giving: location, date of collection, depth, temperature of water, and species of fishes found. There is a list of species, noting the stations from which they were collected and pertinent notes. The muskellunge was taken from Georgian Bay. Colour and pattern of two specimens are briefly described.

Hubbs, C. L. and K. F. Lagler 1939

Keys for the identification of the fishes of the Great Lakes and tributary waters. Ann Arbor, Michigan, published by the authors. $37 \mathrm{pp}$.

The Great Lakes muskellunge referred to as Esox masquinongy masquinongy is included in the key.

Hubbs, C. L. and K. F. Lagler 1941

Guide to the fishes of the Great Lakes and tributary waters. Cranbrook Inst. Sci. Bull. 18. 100 pp.

There is a key to the species of each family present in the Great Lakes area and a short note on the distribution and habitat of each species, including Esox masquinongy masquinongy.

Hubbs, C. L. and K. F. Lagler 1949

Fishes of Isle Royale, Lake Superior, Michigan. Pap. Michigan Acad. Sci. Arts Lett. (1947) 33: 73-133.

Muskellunge included in the list of fishes of Isle Royale.

Hubbs, C. L. and K. F. Lagler 1957

List of fishes of the Great Lakes and tributary waters. Univ. Michigan Dep. Fish. School Nat. Resour. Michigan Fish. 1. 6 pp.

Both the muskellunge Esox masquinongy and the so-called Great Lakes muskellunge Esox masquinongy masquinongy are listed.

Hubbs, C. L. and K. F. Lagler 1964

Fishes of the Great Lakes region with a new preface. Ann Arbor, Univ. Michigan Press. 213 pp.

Key and a brief note that describes distribution and habitat of Esox masquinongy mas- 
quinongy, and mentions two other subspecies, E. m. ohioensis and E. m. immaculatus. (pp. 93-94)

Hunt, J. M. 1966

Miles 'n miles of musky. Ontario Fish Wildl. Rev. 5(2): 16-18.

Short account describing the muskellunge culture programme at Deer Lake Hatchery, Ontario, from artificial spawning of parent stock and fertilization of eggs to hatching and rearing fry.

Hunter, G. W. III and J. S. Rankin, Jr. 1939

The food of the pickerel. Copeia 1939(4): 194-199.

Food taken by pickerel (in this instance the members of the genus Esox) is analysed.

Hvass, H. 1965

Fishes of the world. London, Methuen. $156 \mathrm{pp}$.

The muskellunge is mentioned briefly. (p. 125)

Ivis, F. M. 1902

Maskinonge and bass fishing. Canadian Mag., July: 225-229.

Jackson, J. W. 1958

Musky fishing. What to do and what not to do as told by three old guides to the author. Harrisburg, Pennsylvania, Telegraph Press. 128 pp.

Jackson, M. F. and J. L. Price MS 1949

The preferred temperature of a sample of yearling Esox masquinongy. Univ. Toronto, Ontario Fish. Res. Lab. Libr. 4 pp. Manuscript.

Notes on preferred temperature and the final temperature preferred determined by experiment.

Janes, T. 1966

New muskie water. Outdoor Life 138(1): 36-39, 61-63.

Jarvis, W. 1957

Vermilion muskies. Outdoor Life 119(6): 60-61, 78-82.

Jay, D. 1968

Minnesota tiger hunt. Sportfishing, May: 24-25, 39-40.

Jay, D. 1971

Muskie madness. Argosy, May: 30-33.

Jennings, P. 1957

Muskies in the south. Field Stream, September: 70-72, 107-109, 126.

Jennings, T. L. and F. Frank 1965

Results of an experimental muskellunge-silver northern pike cross. Iowa Conserv. Comm. Q. Biol. Rep. 17(4): 1-3.

Johnson, C. 1929 a

Teasing muskies in a inkwell. For. Stream, February: 102-103, 126-127.

Johnson, C. 1929 b

Up where the Mississippi begins. For. Stream, June: 393-394, 438-439.

Johnson, C. 1942

Autumn muskellunge are good strikers. Sports Afield, October: 75-76. 
Johnson, C. 1952

Facts about big muskies. Sports Afield 128(2): 28-29, 49.

Johnson, L. D. no date

Stomach analysis of pond and lake muskellunge and northern pike. Warm water research. Wisconsin, D-J Proj. F-61-R-1, Job 1b. 5 pp.

Johnson, L. D. 1954 a

A way to find it. Wisconsin Conserv. Bull. 19(5): 5-9.

Account of attempts made to improve muskellunge production in ponds. The stomach contents of small muskellunge and suckers were examined. The causes of mortalities are discussed.

Johnson, L. D. 1954 b

Musky strike - small-scale. Wisconsin Conserv. Bull. 19(7): 22-24.

Author describes observations made on muskellunge (from newly hatched to fingerlings) in aquaria and ponds. Particular reference is made to feeding.

Johnson, L. D. 1954 c

And it didn't get away! Wisconsin Conserv. Bull. 19(8): 16-17.

Report on a record muskellunge containing $81 \frac{1}{4}$ pounds (approximately $3.7 \mathrm{~kg}$ ) of eggs.

Johnson, L. D. $1954 \mathrm{~d}$

Muskellunge culture in ponds. Proc. 16th Midwest Wildl. Conf. 4 pp.

Johnson, L. D. 1956 a

The musky and Warren Herrick. Wisconsin Conserv. Bull. 21(7): 17-19.

Interview with an experienced fisherman.

Johnson, L. D. 1956 b

Musky battle. Wisconsin Conserv. Bull. 21(8): 3-4.

Photographic description of the capture of a muskellunge.

Johnson, L. D. 1958 a

Pond culture of muskellunge in Wisconsin. Wisconsin Conserv. Dep. Tech. Bull. 17, D-J Proj.

F-10-R. 54 pp.

Discusses methods of pond culture used in Wisconsin to rear muskellunge, including food selection. Attempts to control unwanted aquatic vegetation, algae, and predator insect larvae by both physical and chemical methods are described.

Johnson, L. D. 1958 b

Muskellunge growth in Wisconsin. Proc. 20th Midwest Wildl. Conf.: 2-3.

Johnson, L. D. 1959

Muskellunge studies. Wisconsin Conserv. Dep. Res. in Wisconsin (1957-1958): 20-21.

Life history studies of muskellunge were conducted to evaluate stocking and improve propagation. Some of the results of the studies done in Spooner Lake Hatchery and the surrounding area are given under the following headings: food, age and growth, behaviour, age determination, survival, tagging studies, pond culture.

Johnson, L. D. 1960 a

Let's compare muskies. Wisconsin Conserv. Bull. 25(7): 13-16.

Considers the problem of aging muskellunge. There is a table giving length, weight, and age. Variables that affect growth and problems in correctly estimating age are discussed.

Johnson, L. D. 1960 b

Muskellunge studies. Wisconsin Conserv. Dep. Res. in Wisconsin (1958-1959): 13-14.

Results of a continuing study of the muskellunge are discussed. 
Johnson, L. D. $1960 \mathrm{c}$

Muskellunge studies. Wisconsin Conserv. Dep. Res. in W'isconsin (1959): 17-18.

Discusses results of a continuing study on the muskellunge in Wisconsin and the related investigational problems.

Johnson, L. D. $1960 \mathrm{~d}$

"The night of the spider". Wisconsin Conserv. Bull. 25(6): 3-6.

Johnson, L. D. 1960 e

The Wisconsin muskellunge. Badger History, Wisconsin Hist. Soc. 13(7): 14-16.

Johnson, L. D. 1961 a

Warm water fishery research. Muskellunge studies. Stomach analysis of pond and lake muskellunge and northern pike. Wisconsin Conserv. Dep., D-J Proj. F-6l-R-1, wk. pl. 1, Job B: $8-13$.

Johnson, L. D. 1961 b

Warm water fishery research. Muskellunge studies. Evaluation of muskellunge stocking. Wis consin Conserv. Dep., D-J Proj. F-61-R-1, wk. pl. 2, Job B: 20-24

Johnson, L. D. 1962 a

Warm water fishery research. Muskellunge studies. Behavior. Wisconsin Conserv. Dep., D-J Proj. F-61-R-2, wk. pl. 1, Job A. 4 pp.

Johnson, L. D. 1962 b

Warm water fishery research. Muskellunge studies. Stomach analysis of muskellunge and northern pike. Wisconsin Conserv. Dep., D-J Proj. F-61-R-2, wk. pl. 1, Job B: 4-7.

Johnson, L. D. 1962 c

Warm water fishery research. Muskellunge studies. Muskellunge age and growth. Wisconsin Conserv. Dep., D-J Proj. F-61-R-2, wk. pl. 1, Job C: 5, 8-10.

Johnson, L. D. 1962 d

Warm water fishery research. Muskellunge studies. Evaluation of muskellunge stocking. Wisconsin Conserv. Dep., D-J Proj. F-61-R-2, wk. pl. 2, Job B: 13-20.

Johnson, L. D. 1963

The traveling musky. Wisconsin Conserv. Bull. 28(4): 10-11.

Johnson, L. D. 1965 a

Statewide fishery research. Muskellunge studies. Muskellunge behavior. Wisconsin Conserv. Dep., D-J Proj. F-83-R-1, wk. pl. 2, Job A. 2 pp.

Johnson, L. D. 1965 b

Statewide fishery research. Muskellunge studies. Feeding habits of muskellunge. Wisconsin Conserv. Dep., D-J Proj. F-83-R-1, wk. pl. 2, Job B. 6 pp.

Johnson, L. D. 1965 c

Statewide fishery research. Muskellunge studies. Muskellunge age and growth studies. Wisconsin Conserv. Dep., D-J Proj. F-83-R-1, wk. pl. 2, Job C. 8 pp.

Johnson, L. D. 1965 d

Statewide fishery research. Muskellunge studies. Watcr quality of muskellunge habitat. Wisconsin Conserv. Dep., D-J Proj. F-83-R-1, w.k. pl. 2, Job D. 2 pp.

Johnson, L. D. 1965 e

Statewide fishery research. Muskellunge studies. Evaluation of muskellunge stocking. Wisconsin Conserv. Dep., D.J Proj. F-83-R-1, wk. pl. 2, Job E. 9 pp. 
Johnson, L. D. $1965 \mathrm{f}$

The variable muskellunge. Wisconsin Conserv. Bull.: 23-25.

Johnson, L. D. 1966

Factors that influence muskellunge egg mortalities in lakes. Proc. 28th Midwest Fish Wildl. Conf.

Johnson, L. D. 1967 a

Statewide fishery research. Muskellunge studies. Muskellunge age and growth studies. Wisconsin Conserv. Dep., D-J Proj. F-83-R-2, w'k. pl. 2, Job C: 5-32.

Johnson, L. D. 1967 b

Statewide fishery research. Muskellunge studies. Water quality of muskellunge habitat. Wisconsin Conserv. Dep., D-J Proj. F-83-R-2, wk. pl. 2, Job D: 33-67.

Johnson, L. D. 1967 c

Statewide fishery research. Water quality of muskellunge habitat. Wisconsin Conserv. Dep., D.J Proj. F-83-R-3, w'k. pl. 2, Job D. 30 pp.

Johnson, L. D. 1967 d

Statewide fishery research. Muskellunge studies. Evaluation of muskellunge stocking. Wisconsin Conserv. Dep., D.J Proj. F-83-R-2, wk. pl. 2, Job E: 68-72.

Johnson, L. D. 1967 e

Statewide fishery research. Muskellunge spawning and reproduction. Wisconsin Conserv. Dep., D-J Proj. F-83-R-3, wk. pl. 2, Job A. 3 pp.

Johnson, L. D. $1967 \mathrm{f}$

Statewide fishery research. Muskellunge age and growth studies. Wisconsin Conserv. Dep., D-J Proj. F-83-R-3, w'k. pl. 2, Job C. 19 pp.

Johnson, L. D. $1967 \mathrm{~g}$

Statewide fishery research. Water quality of muskellunge habitat. Wisconsin Conserv. Dep., D-J Proj. F-83-R-3, w.k. pl. 2, Job D. 30 pp.

Johnson, L. D. $1967 \mathrm{~h}$

Statewide fishery research. Evaluation of muskellunge stocking. Wisconsin Conserv. Dep., D-J Proj. F-83-R-3, wk. pl. 2, Job E. 5 pp.

Johnson, L. D. 1968 a

Annual progress report 1967. Muskellunge studies. Wisconsin Dep. Nat. Resour. Bur. Res. Mimeograph.

Johnson, L. D. 1968 b

Statewide fishery research. Muskellunge spawning, reproduction, and propagation. Wisconsin Conserv. Dep., D-J Proj. F-83-R-4, wk. pl. 2, Job A. 33 pp.

Johnson, L. D. 1968 c

Statewide fishery research. Evaluation of muskellunge stocking. Wisconsin Conserv. Dep., D-J Proj. F-83-R-4, wk. pl. 2, Job E. 9 pp.

Johnson, L. D. 1968 d

What's "musky water". Wisconsin Conserv. Bull. 33(2): 10-11.

Johnson, L. D. 1969 a

Food of angler-caught northern pike in Murphy Flowage. Wisconsin Dep. Nat. Resour. Tech. Bull. 42.26 pp.

Muskellunge have been stocked in Murphy Flowage but they have poor survival. 
Johnson, L. D. 1969 b

The reliability of age determination assigned to known age muskellunge from scales and fin sections. Proc. 31 st Annu. Midwest Fish Wildl. Conf.

Johnson, L. D. 1971 a

Growth of known-age muskellunge in Wisconsin and validation of age and growth determination methods. Wisconsin Dep. Nat. Resour. Tech. Bull. 49, D-J Proj. F-83-R. 24 pp.

All muskellunge stocked in the study lakes from 1955-1969 were fin clipped so that methods of age and growth determination could be studied.

Johnson, L. D. 1971 b

Statewide fishery research. Development of improved muskellunge stocking procedures. Wisconsin Dep. Nat. Resour., D-J Proj. F-83-R-7, wk. pl. 29, Job 4 and 5. 14 pp.

From gross visual observation, 69 lakes were thought to be suitable for stocking muskellunge. Four of these lakes were intensively studied in 1971.

Data indicated that muskellunge fingerlings were stressed from handling encountered during harvest and transport to the lakes. Conditioning did not increase survival. Lakes with predators had significantly lower muskellunge survival but the predators did not actively seek out the stocking site. Finally there was higher muskellunge survival in lakes with highest weed cover.

Johnson, L. D. $1971 \mathrm{c}$

Weights and conditions of Wisconsin muskellunge. Wisconsin Dep. Nat. Resour. Intra-Dep. Memo. 5 pp.

Johnson, L. D. 1972 a

Musky survival. Wisconsin Conserv. Bull. 37(3).

Describes methods used to study the survival of stocked muskellunge and variability of results obtained. Various reasons for the mortality of newly stocked muskellunge are suggested, including the possibility that mortality is caused by either handling stress or predation.

Measurement of physiological effects of stress indicated a definite physiological response to stress. However, holding muskellunge in pens before releasing them did not increase survival.

Johnson, L. D. 1972 b

Statewide fishery research. Development of improved muskellunge stocking procedures (research). Wisconsin Dep. Nat. Resour., D-J Proj. F-83-R-8, Job 209. 13 pp.

From gross visual observation, 69 lakes were thought to be suitable for stocking muskellunge. Four of these lakes were intensively studied in 1971 and five in 1972.

Data indicated the muskellunge fingerlings were stressed from handling encountered during harvest and transport to the lakes. Conditioning did not increase survival. Lakes with predators had significantly lower muskellunge survival but the predators did not actively seek out the stocking site. Finally there was higher muskellunge survival in lakes with highest weed cover.

Johnson, L. D. 1974 a

Muskellunge survival in Wisconsin lakes. Morehead, Kentucky, Proc. 6th Interstate Muskellunge Workshop, September 25-26: 41-44. Mimeograph.

Analysis of data collected over three years from stocking 14 lakes with muskellunge. Factors that affect survival are ranked in order of importance as follows: aquatic vegetation, length of fingerlings, water temperature, length of predators. Survival varied from 25 per cent to 95 per cent.

Johnson, L. D. 1974 b

Development of improved muskellunge stocking procedures. Wisconsin Dep. Nat. Resour. Bur. Res., D-J Proj. F-83-R-9, Job 209. 19 pp.

Discusses results of a continuing study to determine causes of muskellunge fingerling mortality, just after stocking. Factors thought to be affecting survival are stress caused by finclipping and stocking, and predators. Predators were not found to move into an area that was recently stocked. 
Several pages of tables and figures of stocking data and characteristics of lakes stocked are included.

Johnson, L. D. 1974 c

Survival of stocked muskellunge in Wisconsin lakes. Wisconsin Dep. Nat. Resour. Tech. Bull.

Johnson, L. D. 1975 a

Development of improved muskellunge stocking procedures. Wisconsin Dep. Nat. Resour. Bur. Res., D-J Proj. F-83-R-10, Job 209. 16 pp.

Summarizes results of continuing study to determine causes of muskellunge fingerling mortality. Contains sections on: selection of study lakes, conditioning of fingerlings, movement of predator fish, survival of finclipped fingerlings, size of fingerlings. There are also several pages of tables and figures outlining stocking data.

Johnson, L. D. 1975 b

How many muskies aren't there anymore? Wisconsin Conserv. Bull. 40(5): 20-2l .

Life expectancy of muskellunge calculations based on returns from 1956 to 1973 indicate a high initial mortality of stocked muskellunge

Johnson, L. D. and D. K. Dunham 1956

Murphy flowage: fishing unlimited. Wisconsin Conserv. Bull. 21(8): 7-10.

In order to study the effects of fishing regulations and fishing pressure, a no-limits programme for anglers was set up on Murphy Flowage. The only restriction was that anglers must report all their catch. This opportunity was also to be used to study life history, stocking survival, food, and growth of muskellunge.

Johnson, L. D., J. H. Klingbiel, C. A. Wistrom and A. A. Oehmcke MS 1957 Life history and ecology of the northern muskellunge (Esox masquinongy immaculatus Garrard). Data for Handb. Biol. Data. 6 pp. Manuscript.

Johnson, L. D. and H. Laughlin 1955

The musky story. Wisconsin Conserv. Bull. 20(5): 5-11.

Series of photographs with captions are used to describe the muskellunge culture operations at Spooner Hatchery, Wisconsin.

Johnson, M. and G. C. Becker 1970

Annotated list of the fishes of Wisconsin. Trans. Wisconsin Acad. Sci. Arts Lett. 58: 265-300.

Occurrence of muskellunge in Wisconsin, including populations developing from lakes that were stocked.

Johnson, P. 1949

How the record musky was landed. Wisconsin Conserv. Bull., October: 20-22.

Johnson, P. 1963

The killer of musky rapids. Sports Afield, September: 38-41, 70-73.

Johnson, R. E. 1945

Ever hooked a hybrid. Minnesota Conserv. (Volunteer) 8(49): 18-22.

Jordan, D. S. 1877 a

Contributions to North American ichthyology: based primarily on the collections of the United States National Museum. Vol. 2. U.S. Natl. Mus. Bull. 10. 116 pp.

Esox nobilior is described. (p. 54)

Jordan, D. S. 1877 b

On the distribution of freshwater fishes of the United States. Ann. New York Acad. Sci. 1(4): $92-120$

Esox nobilior reported from Lake Michigan, Lake Huron, and Lake Erie. (p. 104) 
Jordan, D. S. 1878

A catalogue of the fishes of Illinois. Part 4, pp. 37-70. In The natural history of Illinois.

Illinois Lab. Nat. Hist. Bull. 1(2).

Distribution of Esox nobilior in Illinois.

Jordan, D. S. 1882

Report on the fishes of Ohio. Sect. 4, pp. 785-1002. In Zoology and Botany, Part 1, Zoology. Ohio Geol. Surv. 4. 1020 pp.

Information on synonymy, description, diagnosis, habits, and habitat is given for Esox nobilior.

Jordan, D. S. 1884

Manual of the vertebrates of the northern United States, including the district east of the Mississippi River, and north of North Carolina and Tennessee, exclusive of marine species. 4th ed. Chicago, Jansen McClurg. 406 pp.

Short taxonomic description of Esox nobilior.

Jordan, D. S. 1887 a

A catalogue of the fishes known to inhabit the waters of North America, north of the Tropic of Cancer, with notes on the species discovered in 1883 and 1884. U.S. Comm. Fish Fish. Commr. Rep. (1885) 13: 789-973 (1-185).

The muskellunge (or Mascalongus) is listed by the scientific name Esox nobilior.

\section{Jordan, D. S. 1887 b}

The geographical distribution of freshwater food-fishes in the several hydrographic basins of the United States. pp. 133-154. In Goode, G. B. et al., eds. The fisheries and fishery industries of the United States. Sect. 3. Rathbun, R., ed. The fishing grounds of North America. Washington, Government Printing Office.

The muskellunge, Esox nobilior, is included in the lists of fishes present in the Great Lakes drainage and the Upper Mississippi drainage.

Jordan, D. S. 1905

A guide to the study of fishes. Vol. 2. New York, H. Holt. 427 pp.

Brief note gives distinguishing features and distribution.

Jordan, D. S. 1923

A classification of fishes. Including families and genera as far as known. Stanford Univ. Publ. Biol. Sci. 3(2). 243 pp.

Synonymy of generic names of the family Esocidae, including Esox, Lucius, and Mascalongus.

Jordan, D. S. 1925

Fishes. Rev. ed. New York, London, D. Appleton. 773 pp.

Describes the muskellunge, Esox masquinongy, which is said to be found only in the Great Lakes region, whereas a second species, Esox ohiensis, is said to occur sparingly in the Ohio River and upper Mississippi Valley. (p. 411)

Jordan, D. S. 1929

A manual of the vertebrate animals of the northern United States, including the district north and east of the Ozark mountains, south of the Laurentian Hills, north of the southern boundary of Virginia, and east of the Missouri River, inclusive of marine species. 13th ed. Chicago, Jansen, McClurg. $446 \mathrm{pp}$.

Description and distribution of Esox masquinongy.

Jordan, D. S. and H. E. Copeland 1877

Check-list of the fishes of the fresh-waters of North America. Art. 10. Bull. Buffalo Soc. Nat. Hist. (1876) 3: 133-164.

Lists Esox nobilior from Great Lakes region. 
Jordan, D. S. and B. W. Evermann 1923

American food and game fishes. A popular account of all the species found in America north of the Equator, with keys for ready identification. life histories and methods of capture. New York, Doubleday, Page. 574 pp.

The three forms of muskellunge are considered as three distinct species: the muskallunge, Esox masquinongy Mitchill: Chautauqua muskallunge, Esox ohiensis Kirtland; and great north. ern pike, Esox immacularus (Garrard).

There are notes on description, distribution, capture locations, life histories, and angling, and also detailed taxonomic notes. There is also a poem on the muskellunge by Wilcox and a black and white drawing. (pp. 233-234, 237-240)

Jordan, D. S. and B. W. Evermann 1963

The fishes of North and Middle America. Reprint ed. Jersey City, T. F. H. Publications. [U.S. Natl. Mus. Bull. 47(1-4), 1896-1900.] 3313 pp.

In part 1, pages 624 to 630 , there is a key to the genera of the pike family and also a key to the species. Synonymy, description, and distribution are given for Lucius masquinongy, Lucius masquinongy' ohiensis, Lucius masquinongy immaculatus.

Jordan, D. S., B. W. Evermann and H. W. Clark 1930

Checklist of the fishes and fishlike vertebrates of North and Middle America, north of the northern boundary of Venezuela and Colombia. U.S. Commr. Fish. Rep. (1928), Appendix 10, Doc. 1055. 670 pp.

Synonymies for Esox masquinongy, Esox masquinongy ohiensis, Esox masquinongy immaculatus.

Jordan, D. S. and C. H. Gilbert 1882

A synopsis of the fishes of North America. U.S. Natl. Mus. Bull. 16. 1018 pp.

Concise description and synonymy of Esox nobilior.

Jorgensen, W. and J. Jennings 1972

Muskies in Iowa? Iowa Conserv. 31(11): 3-5.

Juday, C. and C. L. Schloemer 1938

Growth of game fish in Wisconsin waters - fifth report. Wisconsin Geol. Nat. Hist. Surv. Notes Limnol. Lab. 26 pp.

Jurgens, J. 1970

So you believe muskies are loners. Minnesota Conserv. Volunteer, March/April: 42-44.

Jurgens, J. 1971

Casting vs. trolling for muskellunge. Gopher Angler, Winter (1970-1971): 27-28.

Jurgens, J. 1972

My 50-inch musky was a throwback. Sports Recreation, September/October: 6-8, 80.

Karas, N. 1966

Musky lake. Sports Afield, April: 31-33, 76, 78, 80, 82-83.

Karas, N. 1971

The new muskie country. Field Stream, January: 54-55, 117, 119, 121, 123, 125, 127.

Karvelis, E. G. 1964

The true pikes. U.S. Fish Wildl. Serv. Fish. Leafl. 569. 11 pp.

Although no specific taxonomic characters are mentioned, nomenclature and distinguishing characters of the genus Esox are given.

Keats, J. 1957

Make mine muskie. Outdoor Life 120(4): 66-67, 115-118. 
Keats, J. 1958

Hell-fire muskie. Field Stream, March: 57-59, 103-107.

Keats, J. 1962

The best kind of bad luck. Sports Afield, August: 22-25, 64, 66 .

Kempinger, J. J. 1967 a

Statewide fishery research. Northern highland research report. Estimation and exploitation of fish populations. Wisconsin Conserv. Dep., D-J Proj. F-83-R-2, wk. pl. 4, Job A. 4 pp.

Kempinger, J. J. 1967 b

Statewide fishery research. Northern highland research project. Evaluation of game fish stocking. Wisconsin Conserv. Dep., D-J Proj. F-83-R-2, wk. pl. 4, Job B: 5-12.

Kempinger, J. J. $1967 \mathrm{c}$

Statewide fishery research. Estimation and exploitation of fish populations. Wisconsin Conserv. Dep., D-J Proj. F-83-R-3, wk. pl. 4, Job A. 3 pp.

Kempinger, J. J. 1967 d

Statewide fishery research. Evaluation of game fish stocking. Wisconsin Conserv. Dep., D-J Proj. F-83-R-3, wk. pl. 4, Job B. 6 pp.

Kempinger, J. J. 1969

Escanaba Lake muskellunge data 1964-1968. Wisconsin Dep. Nat. Resour. Intra-Dep. Memo.

Kempinger, J. J. 1970

Statewide fishery research. Estimate of abundance and exploitation of the fish population of Escanaba Lake, Wisconsin. Wisconsin Conserv. Dep., D-J Proj. F-83-R-5, wk. pl. 21, Job 7 , Fin. 50 pp.

Kempinger, J. J. 1972

Muskellunge fishing on Escanaba Lake with liberalized fishing regulations, 1946-1971. Wisconsin Dep. Nat. Resour. Bur. Res. 6 pp. Mimeograph.

The muskellunge population in Escanaba Lake, Wisconsin, was studied from 1946 to 1972 , by creel census and netting. Fish collected in nets were tagged. Fingerling and yearling muskellunge about to be stocked were marked by the removal of the pectoral fin. Stocking of muskellunge in 1961 was followed by an increased angler harvest but the stockings of muskellunge in 1965 and 1966 were not. Data are summarized in tables. The muskellunge population in the lake was considered to be not very abundant.

Kempinger, J. J., W. S. Churchill, G. R. Priegel and L. M. Christenson 1975

Estimate of abundance, harvest, and exploitation of the fish population of Escanaba Lake, Wisconsin, 1946-69. Wisconsin Dep. Nat. Resour. Tech. Bull. 84. 30 pp.

Briefly outlines angler harvest of muskellunge from Escanaba Lake from 1946 to 1969 and the contribution of the stocking of fingerling muskellunge.

Kendall, W. C. 1919

The pikes: their geographical distribution, habits, culture, and commercial importance. U.S. Dep. Commerce Commr. Fish. Rep. (1917) Appendix 5, Bur. Fish. Doc. 853. 45 pp.

This account on the muskellunge, Esox masquinongy, includes notes on colour, markings, naming, distribution, size, habitat and habits, artificial culture, conservation, food qualities, and as a game fish.

King, F. 1963

Man of many muskies. Sports Afield, June: 54-55, 96. 
Kirby, E. 1957

Reflections on catching the big one. Wisconsin Conserv. Bull. 22(5): 29.

A novice angler's account of catching a muskellunge.

Kirsch, P. H. 1894

A report upon investigations in the Maumee River Basin during the summer of 1893. U.S. Fish Comm. Bull. 14: 315-337.

Muskellunge reported from Maumee River and Lake Erie.

Kirtland, J. P. 1838 a

A catalogue of the mammalia, birds, reptiles, fishes, testacea, and crustacea in Ohio. Ohio Geol. Surv. Ist Annu. Rep.

Esox estor (muskellunge) was found exclusively in Lake Erie with one exception. It was often confused with the common pike. (p. 160)

Kirtland, J. P. 1838 b

Report on the zoology of Ohio. Ohio Geol. Surv. 2nd Annu. Rep.: 157-197.

Kirtland, J. P. 1847

Descriptions of the fishes of Lake Erie, the Ohio R ver, and their tributaries. Art. 24. Boston J. Nat. Hist. (1845-1847) 5: 330-344.

Gives a description and synonymy for Esox estor, which is said to have been incorrectly described by Lesueur. Proposes that Lesueur had a specimen of E. reticulatus. E. estor is compared with $E$. reticulatus. Briefly outlines distribution.

Kirtland, J. P. 1851

Esox estor Les. - muskallonge. Cleveland Family Visitor 2(8): 61.

Kirtland, J. P. 1854

Revision of the species belonging to the genus Esox, inhabiting Lake Erie and the River Ohio. Ann. Sci. 2(3): 78-79.

Considers Esox nobilis to be the proper scientific name for the muskellunge and not E. estor (=pike). Synonymies of both given. A species said to be distinct from either is described $(E$. ohioensis).

Kleeberg, G. S. P. 1924

An Alexandria Bay "musky". For. Stream, October: 590-620.

Kleinert, S. J. and P. E. Degurse 1972

Mercury levels in Wisconsin fish and wildlife. Wisconsin Dep. Nat. Resour. Tech. Bull. 52. $22 \mathrm{pp}$.

Specimens of fish were collected and analysed for mercury content. The muskellunge was one of the species collected and analysed although it constituted less than 0.5 per cent of all fish sampled. Results were summarized by station or watershed rather than by species. All fish analysed contained mercury but levels less than $0.5 \mathrm{ppm}$ were considered background levels naturally present in fish.

Kleinert, S. J. and D. Mraz 1966

Life history of the grass pickerel (Esox americanus vermiculatus) in southeastern Wisconsin. Wisconsin Conserv. Dep. Tech. Bull. 37. 40 pp.

Klingbiel, J. 1962

To catch a musky. Wisconsin Conserv. Bull. 27(5): 26.

Klingbiel, J. 1963

The muskellunge harvest in northwestern Wisconsin. Wisconsin Conserv. Dep. Northwest Area Invest. Memo 8.9 pp. 
Ḱlingbiel, J. 1966

An evaluation of stocking large muskellunge fingerlings. Wisconsin Conserv. Dep. Fish Manage. Div. Manage. Rep. 3. 11 pp.

Klingbiel, J., H. Laughlin and M. Bachler 1959

A muskellunge tank-rearing project. Wisronsin Conserv. Dep. Fish Manage. Div. Northwest Area Invest. Memo. 3. 9 pp.

Klingbiel, J. and L. E. Morehouse 1954

Does musky stocking pay? Wisconsin Conserv. Bull. 19(10): 17-19.

Tagged muskellunge were stocked in High and Fishtrap lakes in 1950 and 1951. At the time of this report (1954) some of the legal-sized ones were being reported by anglers. It appeared at that time the stocking programme had been fairly successful.

Klingbiel, J. and A. A. Oehmcke 1958

A closed circuit battery for the incubation and hatching of muskellunge and sucker eggs. Wisconsin Conserv. Dep. Fish Manage. Div. Northeast Area Invest. Memo. 1. 5 pp.

Compared hatching success in an experimental hatching battery in which the water temperature was controlled to hatching success in the main battery. Muskellunge eggs hatched earlier in the experimental battery but percentage clean-up was lower than in the main battery.

Knourek, F. J. 1972

Best system for catching muskies. Field Stream, April: 68-69, 211, 213, 215, 217.

Knourek, F. J. 1973

Catch more muskies! Field Stream, June: 64-65, 114-117.

Kreil, A. L. 1969

Statewide fisheries investigations. Air aqua system research in Rolette County. North Dakota Game Fish Dep., D-J Proj. F-2-R-15, Job 8. 29 pp.

Krommer, R. S. 1971

Speed up for muskies. Outdoor Life 148(2): 74-75, 96, 98, 100.

Krotzer, K. 1959

Muskies aren't so tough. Outdoor Life 124(1): 48-89, 91, 112-113.

Krumholz, L. A. 1949

Length-weight relationship of the muskellunge, Esox m. masquinongy, in Lake St. Clair. Trans. Am. Fish. Soc. (1947) 77: 42-48.

Data on the relationship between the total length and weight of the muskellunge, Esox m. masquinongy, based on measurements of 264 fish caught by anglers from Lake St. Clair are presented. The fish ranged in length from 30 to 54 inches $(762-1372 \mathrm{~mm})$ and in weight from 6.5 to 37 pounds $(2.9-16.8 \mathrm{~kg})$. The plotting of weights of individual fish against their respective lengths indicated a definite relationship between those measurements. Agreement was close between the data on muskellunge from Lake St. Clair and muskellunge (Esox $\mathrm{m}$. ohiensis) from Chautauqua Lake, New York. Similar data on muskellunge (probably some Esox m. immaculatus and E. m. masquinongy) from scattered inland lakes of Michigan indicated that those fish may be slightly heavier than individuals from Lake St. Clair. (Author's abstract)

Kuhne, E. R. 1938

Tennessee's fisheries program. Trans. Am. Fish. Soc. 68: 240-245.

Kuhne, E. R. 1939

A guide to the fishes of Tennessee and the mid-south. Tennessee Dep. Conserv. Div. Game Fish. 124 pp.

There is a paragraph note on the Ohio muskellunge, Esox masquinongy ohioensis. (p. 73) 
Laarman, P. W. 1963

Average growth rates of fishes in Michigan. Michigan Dep. Conserv. Inst. Fish. Res. Div. Fish. Rep. 1675. 9 pp.

Muskellunge growth data.

Laarman, P. W. 1964

Research and management of sport fisheries of Michigan. Age and growth of fishes. Age and growth. Michigan fishes. Michigan Dep. Conserv., D-J Proj. F-27-R-2, wk. pl. 8, Job 1. 11 pp.

Routine age determinations were made by P. W. Laarman from scales collected by personnel of the Institute and the Fish Section. The data were tabulated, summarized, and summaries were provided for the people concerned.

The growth rate averages for most of the game (and some of the non-game) fishes of Michigan were revised.

The influence of certain environmental factors on fish growth was evaluated in a special study, and the average lengths attained monthly by age groups of the bluegill, yellow perch, and largemouth bass were determined. (Author's abstract)

Lagler, K. F. 1956

Freshwater fishery biology. 2nd ed. Dubuque, lowa, W. C. Brown. 421 pp.

There are notes on spawning and the early life history of the muskellunge. Considered to be both a sport fish and a coarse food fish. (pp. 38-39, 393)

La Monte, F. 1945

North American game fishes. Garden City, Doubleday, Doran. 202 pp.

Under the heading Esox masquinongy there is a brief note on names, distribution, colour, distinguishing characters, size, and food habits. There is also a note on names and distinguishing markings under each of Esox masquinongy ohiensis, the Chautauqua muskellunge, and Esox masquinongy immaculatus, the northern muskellunge. There are black and white illustrations depicting Esox masquinongy and Esox masquinongy ohiensis.

Lane, T. 1966

Out of the rucksack. Sports Recreation, March/April: 53, 77.

Langlois, T. H. 1930

The Ohio conservation program. Ohio Div. Conserv. Bur. Fish Propagation Prog. Bull. 35: 23-25.

Langlois, T. H. 1945

Water, fish and cropland management. Trans. 10th North Am. Wildl. Conf.: 190-196.

Langlois, T. H. 1954

The western end of Lake Erie and its changed ecology. Ann Arbor, Michigan, J. W. Edwards Publ. 479 pp.

Larson, V. 1964

Creek muskies. Fur-Fish-Gaoe, January: 30-31.

Lawrence, H. L. 1967

Muskies you-all! Garcia Fish. Annu.: 17-19.

Lawrence, J. D. 1907 a

The maskalonge. Report on the state hatcheries for the year 1905. New York For. Fish Game Commr. 10th, 1lth, 12th Annu. Reps. (1904, 1905, 1906): 162-171.

Discusses problem of decreasing catch of muskellunge in Chautauqua Lake. Includes letter from W. H. Knapp to the Commission. 
Lawrence, J. D. 1907 b

Report on the state hatcheries for the year 1906. New York For. Fish Game Commr. 10th, 11 th, 12th Annu. Reps. (1904, 1905, 1906): 172-176.

Describes success of restocking the St. Lawrence River. Includes colour drawing of Lucius ohiensis.

Lawton, A. 1958

Biggest muskie yet. Outdoor Life 121(6): 70-71, 90-93.

Leach, G. C. 1927

Artificial propagation of pike perch, yellow perch and pikes. U.S. Dep. Commerce Comm. Fish. Rep. Appendix 1, Bur. Fish. Doc. 1018. 26 pp.

Discusses the pike family of fishes with particular reference to each species. Information on the muskellunge can be found in the following sections: description, geographical distribution, distinguishing marks, food, habits and rate of growth, and artificial propagation.

LeBlanc, H. 1969

Tricks of a musky guide. Sports Afield Fish. Annu.: 41-45.

LeBlanc, H. 1974

Forty years on muskies. Fish. Facts, November: 14-15, 17-19, 21, 23, 25.

Le Danois, E. no date

Fishes of the world. Vermont, Countryman Press. 190 pp.

Short, incorrect note on the muskellunge. Black and white illustration.

Lee, G. R. 1957

How to catch a musky. Sports Afield, July: 19-23, 74-75.

Legendre, V. MS 1950

Esocidae: size, counts, descriptions from various authors, with the purpose of finding the proper systematic name of the maskinonge. 7 pp. Manuscript.

An accumulation of information, which was put together to indicate what scientific name should properly be given to the muskellunge. Summarizes the counts given to differently named species by various authors.

Legendre, V. MS 1952 a

The pike of Quebec: the ogres of our waters. Quebec Dep. Fish Game Off. Biol. 42 pp. Manuscript.

Written for the purpose of aiding the inexperienced in identifying members of the family Esocidae, including the muskellunge. The methods that are used to determine accurately the distinguishing characters for each species are carer̂lly described and illustrated by line drawings. The patterns and markings characteristic of each species are shown in drawings. There is a key for identification and a short account outlining distribution for each species.

Legendre, V. MS $1952 \mathrm{~b}$

Les brochets du Québec: les ogres de nos eaux. 42 pp. Manuscrit.

Legendre, V. 1952 c

Les poissons d'eau douce. Clef des poissons de pêche sportive et commerciale de la province de Québec. Tome 1. Montréal, Soc. Canadienne Ecol. 84 pp.

Legendre, V. 1953

Les poissons d'eau douce de la province de Québec: liste des espèces, groupes écologiques, historique, nomenclature, annotations. [The freshwater fishes of the Province of Quebec: list of the species, ecological groups, history, nomenclature, annotations.] Québec Minist. Chasse Pêch. Rapp. Off. Biol. (1950-1952) 9: 190-294. [In French and English.] 

lunge.

Lists scientific name and French and English common name for two "species" of muskel-

Legendre, V. $195+$ a

The freshwater fishes. Vol. 1. Key to game and commercial fishes of the province of Quebec. Montreal, Soc. Canadienne Ecol., Quebec Game Fish. Dep. 180 pp.

A distinction is made between Esox masquinongy masquinongy and Esox masquinongy ohiensis. Esox masquinongy ohiensis is said to not be indigenous to Quebec. There are black and white figures of both the St. Law rence muskellunge and the Ohio muskellunge, and both of the so-called subspecies appear in the key.

Legendre. V. 1954 b

Les poissons d'eau douce. Tome 1. Clef des poissons de pêche sportive et commerciale de la province de Québec. Montréal, Soc. Canadienne Ecol., Québec Minist. Chasse Pêch. 180 pp.

Refer to English edition (Legendre, 1954 a).

Legendre, V. 1971

L'ichthyogéographie du Québec et la documentation corrélative. Québec Minist. Tourisme Chasse Pêche Serv. Faune Bull. 12. 71 pp.

Lists a few references on the muskellunge.

Le Sueur, C. A. 1818

Description of several new species of the genus Esox, of North America. J. Acad. Nat. Sci. Philadelphia 1(2): 413-417.

The description of the species named Esor estor is quite likely one of the earliest published descriptions of the muskellunge.

Levy, H. M. 1962

Man against musky. Stories of the muskellunge, king of fresh waters. Harrisburg, Pennsylvania. Stackpole. $221 \mathrm{pp}$.

Lewis, B. 1968

The lost case against musky fishing. Wisconsin Conserv. Bull., May/June: 25 .

Liegey, F., E. H. Donahue and S. W. Eaton 1955

The fishes of Olean Creek, Cattaraugus Co., New York. St. Bonaventure Univ. Sci. Stud. 17: $5-25$.

No muskellunge taken during the study but relates catches by several fishermen.

Lienhard, J. 1961

Hill country pike. Fur-Fish-Game, July: 16-17, 47.

Lincicome, D. R. and H. J. Van Cleave 1949

Distribution of Leptorhynchoides thecatus, a common acanthocephalan parasitic in fishes. Am.

Midl. Nat. 41(2): 421-431.

Esox masquinongy included in the geographical list of hosts of Leptorhynchoides thecatus.

Lincoln, R. P. 1921

Fishing for the pikes in autumn. For. Stream, November: 494-495, 522-523.

Lincoln, R. P. 1922

Autumn fishing for the pikes. For. Stream, October: $442-443,470-472$.

Lincoln, R. P. 1948

Pad fishing for muskellunge. Field Stream, January: 69-71. 
Lincoln, R. P. 1953

The pike family. Harrisburg, Pennsylvania, Stackpole. 274 pp.

Lind, J. A. 1964

Muskie! The study of the fabulous muskie. Chicago, McCormick and Henderson. 204 pp. Treasury of information for the angler.

Lindner, A. 1971

Old musky myths exploded - new truths revealed! Fish. Facts, August: $38-44$.

Lindner, B. 1976

A quick course on muskie lakes. Fins Feathers, August: 10-12, 51.

Lindner, R. 1971

Old musky myths exploded - new truths revealed! Fish. Facts, July: 44-48.

Lindsey, A. J. 1970

Goofy muskie and pike. Fur-Fish-Game, June: 24-26.

Lockhart, J. 1957

The musky I never got. Sports Afield, July: 32-35.

Lopinot, A. C. no date

Illinois fish conservation teachers manual. Illinois Div. Conserv. Educ. 69 pp.

Explains that pike are distinguished from muskellunge by the scalation of the cheek.

Lovett, R. J., W. H. Gutenmann, I. S. Pakkala, W. D. Youngs and D. J. Lisk 1972 A survey of the total cadmium content of 406 fish from 49 New York State fresh waters. J. Fish. Res. Board Canada 29(9): 1283-1290.

The muskellunge was one of the fish surveyed for total cadmium.

Lucas, J. 1952

The maddening muskellunge. Sports Afield, January: 34-35, 63-65.

Lucas, J. 1953 a

Let's get the pickerel straight. Sports Afield, June: 19-23.

Lucas, J. 1953 b

Want a big pike or muskellunge? Sports Afield, November: 86-89.

Lucas, J. 1959

The mighty muskellunge. Sports Afield, June: $38-41,78$.

Lucas, J. 1960

Big pike and muskellunge. Sports Afield, November: 104-106.

Lucas, J. 1962

The pikes. Sports Afield, June: 100, 102-103.

Lynde, H. 1891

The wolf of the waters. For. Stream, January.

McAllister, D. E. 1959

Fish remains from a 600-year-old St. Lawrence River Iroquois site. Natl. Mus. Canada Contrib. Zool. Bull. 172: 33-38.

Various fish skull remains were determined to be a species of Esox, either Esox masquinongy or Esox lucius. 
McAllister, D. E. 1962

Fish remains from Ontario Indian sites 700 to 2500 years old. Natl. Mus. Canada Nat. Hist. Pap. 17. 6 pp.

A $56 \mathrm{~mm}$ maxillary found in the Goessens site belongs to either Esox lucius or Esox masquinongy.

McAllister, D. E. 1968

A list of fishes of the Ottawa area. Trail Landscape 2(4): 141-168.

Esox masquinongy is listed as a fish present in the Ottawa area.

McAllister, D. E. and B. W. Coad 1974

Fishes of Canada's National Capital Region. Canada Dep. Environ. Fish. Mar. Serv. Misc. Spec. Publ. 24. 200 pp.

A drawing, diagnosis, description, the probable glacial refugium, an account of the biology, and a spot distribution map are given for each of the fish species, including the muskellunge.

McAllister, D. E. and E. J. Crossman 1973 a

A guide to the freshwater sport fishes of Canada. Natl. Mus. Nat. Sci. Canada Nat. Hist. Ser. 1. $89 \mathrm{pp}$.

Illustration, distribution map, and short account describing: differences from other Esox, size, habits, and habitat. Contains colour photographs.

McAllister, D. E. and E. J. Crossman 1973 b

Poissons de pêche sportive d'eau douce du Canada. Canada Mus. Natl. Sci. Nat. Collect. Hist. Nat. $1.91 \mathrm{pp}$.

See annotation for English edition.

McCarraher, D. B. 1960

Pike hybrids (Esox lucius $\times E$. vermicularus) in a sandhill lake, Nebraska. Trans. Am. Fish. Soc. 89(1): 82-83.

Reviews previously reported muskellunge hybrids.

McClane, A. J., ed. 1951

The wise fishermen's encyclopedia. New York, W. H. Wise. 1336 pp.

McClane, A. J. 1953

A sucker's game. Field Stream, June: $66-68$.

McClane, A. J. 1954

The American angler. Field Stream Outdoor Ser., New York, H. Holt. 207 pp.

Primarily discusses angling for the northern pike with interjections on the muskellunge and pickerel. There is an age-total length table and a table giving capture records for 50 of the largest fish taken over a 10-year period, (pp. 109-130, 114, 129)

McClane, A. J. 1961

The pike family. Field Stream, June: 40-47, 89-92.

McClane, A. J., ed. 1965

McClane's standard fishing encylopedia and international angling guide. New York, Holt, Rinehart and Winston. $1057 \mathrm{pp}$.

This is a concise, informative account on the biology of the muskellunge. The muskellunge is described, and the origin of names that have been applied is discussed. The rest of the account is given under the following headings: subspecies, evolution and distribution, spawning, habitat, age and growth, feeding habits, fishing for muskellunge, how to boat muskellunge, and fishing techniques. (pp. 580-584) 
McCleave, J. D. 1964

Movement and population of the mottled sculpin (Cortus bairdi Girard) in a small Montana stream. Copeia 1964(3): 506-513.

In the discussion on population estimates, reference was made to Crossman (1956) who employed mark-and-recapture techniques to estimate stream populations of muskellunge.

McCormick, L. N. 1892

Descriptive list of the fishes of Lorain County, Ohio. Oberlin Coll. Lab. Bull. 2. 33 pp.

McCormick, N. A. 1924

Insulin from fish. Fish. Res. Board Canada Bull. 7. 23 pp.

McCrimmon, H. R. 1956

Fishing in Lake Simcoe. Ontario Dep. Lands For. 137 pp.

See MacCrimmon and Skobe (1970).

\section{MacCrimmon, H. R. and E. Skobe 1970}

The fisheries of Lake Simcoe. Ontario Dep. Lands For. Fish Wildl. Branch. 140 pp.

The history of the muskellunge in Lake Simcoe, including commercial fishing returns, plantings, and a growth curve, is discussed. Information on the muskellunge is given under the following headings: life history, food, angling, regulations and management. (pp. 85-90 and provisional checklist p. 136)

MacDonald, B. 1950

The guide that got away. Field Stream, May: 64-65, 134-135, 152-153.

McFadden, J. T. 1964

Trout, walleye, musky and pike. Michigan Conserv. Bull. 33(3): 14-16.

Briefly discusses the possibility of stocking muskellunge in some Michigan lakes.

McGregor, J. F. 1970

The chromosomes of the maskinonge (Esox masquinongy). Can. J. Genet. Cytol. 12(2): 224-229.

The air-drying techniques and aceto-orcein stain were used on uncultured kidney cells from juvenile maskinonge, Esox masquinongy, to determine the chromosome number and karyotype. A somatic chromosome number of $2 n=50$ was found in 88 percent of 200 wellspread colchicine metaphases. Karyotype analysis showed that all the chromosomes have their centromeres located in the terminal region. Chromosmal polymorphisms reported by others for kidney cells of fish were not observed in this study. (Author's abstract)

MacGregor, J. M., J. A. Scott and B. C. Dean 1960

A review of the life history and the proposed management of the northern muskellunge. Michigan Dep. Conserv. Fish. Div. Lake Stream Improvement Rep. 100. 19 pp.

McIntosh, W. C. 1901

The emperor of Wisconsin waters. For. Stream, July: 6.

MacKay, H. H. 1931

The maskinonge and its conservation. Ontario Dep. Game Fish. Biol. Fish Cult. Branch Bull. 1. $11 \mathrm{pp}$.

General information about the muskellunge is given, such as naming, distinguishing features, distribution, and life history. Describes fish culture methods used at the time and efforts made to conserve the stock.

MacKay, H. H. 1956

The maskinonge. Sylva 12(4): 25-32.

The following subjects are discussed: derivation of common name, scientific name, effect of glaciation on muskellunge populations, distribution, description, method of distinguishing 
from northern pike, habitat, habits, spawning, game qualities, economic value, rescarch on shedding of teeth and management. Colour illustration.

Mackay, H. H. 1963

Fishes of Ontario. Ontario Dep. Lands For. 300 pp.

Discussion of the biology, habits, and habitat of the muskellunge, with reference to recent research findings and particular reference to studies and applications in Ontario. Attempts to explain some misconceptions such as shedding of teeth, the three forms (commonly called subspecies), and the "true tiger" hybrid.

Mackay, H. H. and W. H. R. Werner 1934

Some observations on the culture of maskinonge. Trans. Am. Fish. Soc. 64: 313-317.

Mcheaque, H. T. and I. C. Rheaume 1956

Hints for good fishing in Wisconsin. Wisconsin Conserv. Bull. 21(6): 7-10.

Angling tips for various species of fish including the muskellunge.

McKnight, T. 1974

Gas bubble phenomenon in muskellunge eggs. Wisconsin Dep. Nat. Resour. Bur. Fish Wildl. Manage. Sect. Rep. 72.

McNally, T. 1971

Mania for muskies. Garcia Fish. Annu.: 18-22.

MacQuarrie, G. 1953

How Wisconsin saved the muskie. Sci. Digest, July: 44-47.

MacQuarrie, G. 1956 a

The lure of musky fishing. Sports Afield, July: 26-29, 73-75.

MacQuarrie, G. 1956 b

The twelve days. Outdoor Life 116(3): 62-63, 135-137.

MacQuarrie, G. and P. Drotning 1947

Everybody wants a muskie. Wisconsin Conserv. Bull., November: 21-23.

Macins, V. 1972

The fisheries of Lake of the Woods. Ontario Min. Nat. Resour. Sport Fish. Branch. 44 pp. Page-long note on the muskellunge, which is in the provisional checklist of Lake of the Woods fishes.

Madden, K. M. and A. D. Lynch 1962

Notes on the first rearing and introduction of Esox masquinongy in Iowa waters. Proc. Iowa Acad. Sci. 69: 273-277.

The Iowa State Conservation Commission purchased 1,535 muskellunge ( $3 / 4-1$ inch fry) in 1960, from "Kenu", a Land-O-Lakes, Wisconsin, commercial fish hatchery and rearing pond facilities were used for the experimental rearing project. Eighty-five fish survived the June 7 to September 30 rearing period. Forty fish were stocked in each of the following Iowa lakes: West Okoboji, Dickinson County and Clear Lake, Cerro Gordo County. Two specimens have subsequently been recovered and identified from each lake. (Authors' abstract)

Malz, C. 1974

The truth about muskies. Fish. Facts, June: 14-17, 20, 22, 24, 27-28.

Mann, J. 1955

Subject: muskies. Ohio Conserv. Bull. 19(5). 
Marshall, J. 1964

The mighty muskie gets a helping hand. Hunting Fish. In Canada, September: 35 .

Martin, J. 1974

30 Inches is legal. Fur-Fish-Game, April: 24-26.

Martin, R. 1970 a

Buckeye's spring menu. Fish. Hunting Guide, February: 24-25.

Martin, R. 1970 b

Float the Allegheny for musky. Fish. Hunting Guide, March: 13.

Martin, R. 1970 c

Shhh - New southern Ohio musky hotspot. Fish. Hunting Guide, May: 9, 49.

Martin, R. $1970 \mathrm{~d}$

State choice for buckeye muskie. Fish. Hunting Guide, July: 6.

Mather, F. 1886 a

Maskinonjé, mascallunge, maskinauga. For. Stream, March: 18.

Mather, F. 1886 b

Maskinonjé, mascallunge etc. For. Stream, October: 28.

Mather, F. 1898

Fresh water angling - no. VI: pickerel, pike and mascalonge. For. Stream 50(21): 410-412.

Mattis, G. C. 1956

King of the inland game fish. Sports Afield Fish. Annu.: 82-87.

Mattis, G. C. 1964

Recollections of a musky man. Sports Recreation, July/August: 8-9, 65 .

Mattis, G. C. 1966

Louie Spray and musky fever. Sports Recreation, July/August: 10-11.

Mattis, G. C. 1970

How to catch a musky. Sports Recreation, July/August: 6-7, 69 .

Maynard, P. 1970

South Otselic muskellunge experiment. New York Fish News 32: 17-20.

Meek, S. E. and R. Newland 1886

A review of the species of the genus Esox. Proc. Acad. Nat. Sci. Philadelphia (1885) 3: 367-375.

Key, synonymy, origin of each description, and notes on habitat for each species.

Mélançon, C. 1958

Les poissons de nos eaux. 3rd ed. Soc. Zool. Québec. 25 pp.

Short description of the merits of the fish.

Mellen, I. M. 1917

Twenty four ways of spelling the name of a fish (muskallunge). New York Zool. Soc. Bull. 20: 1558.

Mellen, I. M. 1919

Report of the Director of the aquarium. New York Zool. Soc. 23rd Annu. Rep.: 16-33. Mentions a muskellunge that lived ten years in the aquarium. 
Merrilees, M. J. MS 1972

Relationship between the lateral line sensory system and the cardioid scale pits in the family Esocidae (Salmoniformes). Univ. Toronto, Ph. D. thesis. 195 pp.

Details on sensory and non-sensory structures associated with notched scales of various esocids.

Merrilees, M. J. and E. J. Crossman 1974

Species and geographic variability of surface pits in the Esocidae. Copeia 1974 (4): 893-909.

In the Esocidae, the lateral line system consists of shallow pits, each containing a group of neuromasts and partially bordered by a notched (cardioid) scale. The number and location of sensory pits show specific variability but little intraspecific geographic variability. Nonsensory pits (do not contain neuromasts) do show geographic variability but are not present in the musekllunge.

Meseroll, S. 1974

Mountaineer muskies. Outdoor Life 153(6): 82-83, 155-158.

Michaels, C. 1970

How to turn on the moody muskies. True's Fish. Yearbook: 66-69, 88-90.

Migdalski, E. C. 1962

Angler's guide to the fresh water sport fishes of North America. New York, Ronald Press. 431 pp.

This account discusses common names, reason for accepting one species, range, colour and markings, size, maturity, spawning, competition with northern pike, and angling for the muskellunge. It is said that when lampreys have wiped out the trout they turn to other fish, including the muskellunge. (pp. 32, 192, 264-268)

Miles, H. M. 1972

Statewide fishery research. Physiological responses of hatchery reared muskellunge, Esox masquinongy, to handling. Wisconsin Conserv. Dep., D-J. Proj. F-83-R-7, wk. pl. 29, Job 3. $23 \mathrm{pp}$.

Miles, H. M., S. M. Loehner, D. T. Michaud and S. L. Salivar 1972

Physiological responses of hatchery reared muskellunge (Esox masquinongy) to handling. Wisconsin Dep. Nat. Resour., D-J Proj. F-83-R. 23 pp.

Changes in hematocrit, plasma dissolved solids, and concentrations of plasma glucose and chloride, blood lactate, and liver glycogen concentrations were measured in fingerling muskellunge in response to various handling procedures. The procedures examined were pond harvest by seining, fin-clipping, 0.3 percent saline treatment, transportation by oxygen truck, and holding in the lake for 48 hours before release. The degree of stress as reflected by physiological parameters was greatest following initial capture by seining. Treatment in saline alleviated some of the symptoms while fin-clipping and transport showed little additional effect. Holding the fish in the lake before release resulted in no significant change in physiological parameters from the time of introduction to the lake and their release 48 hours later. (Authors' abstract)

Miles, H. M., S. M. Loehner, D. T. Michaud and S. L. Salivar 1974

Physiological responses of hatchery reared muskellunge (Esox masquinongy) to handling. Trans. Am. Fish. Soc. 103(2): 336-342.

Increases in plasma lactate and glucose concentrations, along with decreases in plasma chloride and liver glycogen concentrations, were observed in muskellunge in response to capture and handling. Holding muskellunge in 0.3 percent $\mathrm{NaCl}$ alleviated some of the physiological symptoms of stress, but holding the fish in the lake for 48 hours before release had no effect. Physiological responses to fin-clipping and transport by truck were slight in comparison to that of original capture. Salt treatment and reduction in duration and frequency of handling is recommended. (Authors' abstract) 
Miles, R. L. 1970

Stream and lake survey. Muskellunge life history studies. West Virginia Div. Game Fish, D-J Proj. F-10-R-12, wk. pl. 4, Job 1. 10 pp.

Miles, R. L. 1974

Muskellunge life history study. West Virginia Dep. Nat. Resour., D-J Proj. F-10-R-16, wk. pl. 2, Job 1. 24 pp.

Miller, F. E. 1963

First muskie. Fur-Fish-Game, June: 34-35.

Miller, J. and $\mathbf{K}$. Buss no date

The age and growth of fishes in Pennsylvania. Pennsylvania Fish Comm. Conserv. Educ. Comm. 26 pp.

Includes age and growth studies of the muskellunge.

Montpetit, A.-N. 1897

Les poissons d'eau douce du Canada. Montréal, C. O. Beauchemin et fils, Libraires1 mprimeurs. 552 pp.

This lengthy account on the muskellunge, here referred to as Esox nobilior, is written in French. There is a black and white and colour illustration at the beginning of the book. (pp. 76-80)

Mooradian, S. R. and W. F. Shepherd 1973

Management of muskellunge in Chautauqua Lake. New York Fish Game J. 20(2): 152-157.

Discussion of the management program initiated in 1941 because of the decline in the muskellunge fishery in Chautauqua Lake, New York. Both restrictive regulations and maintenance stocking were commenced. Studies done from 1961 to 1971 indicated hatchery-stocked muskellunge are important in improving the fishery.

Moore, E. 1926

Culture of the maskinonge ("Muskellunge"). New York Conserv. Comm. Annu. Rep. (1925): 131-137.

Moore, E. 1938

Introduction, pp. 9-47. In A biological survey of the Allegheny and Chemung watersheds. New York Conserv. Dep. Suppl. 27th Annu. Rep. (1937), Biol. Surv. 12. 287 pp.

Outlines results of survey of Allegheny and Chemung watersheds including fish planting (1927-1936), creel census, and management recommendations. Includes black and white illustrations of the muskellunge.

Moore, E. and staff 1938

A creel census at Chautauqua Lake, New York. Trans. Am. Fish. Soc. (1937) 67: 130-138.

A creel census of Lake Chautauqua anglers was undertaken as the initial step in a study of angling conditions to determine a management program. During the five-day census period, 80 muskellunge were caught. They represented 2.1 per cent of the total fish catch or an average of 0.05 muskellunge per angler per day.

Moore, G. A. 1968

Fishes. Part 2, pp. 21-166. In Blair, W. F., A. P. Blair, P. Brodkorb, F. R. Cagle and G. A. Moore. Vertebrates of the United States. 2nd ed. New York, McGraw-Hill. 616 pp.

Contained in this volume are a key and a paragraph note on the muskellunge, giving description and range.

Moore, H. H. and R. A. Bream 1965

Distribution of fishes in U.S. streams tributary to Lake Superior. U.S. Fish Wildl. Serv. Spec. Sci. Rep. Fish. 516. 61 pp. 
Morikubo, S. 1929

Fly fishing for muskies. For. Stream, August: 568-569, 615-616.

Morikubo, S. 1930

Down the Flambeau. For. Stream, January: 24-25, 77-78.

Morris, A. G. 1967

Muskellunge in Missouri. Missouri Conserv. 28(2): 1-3.

Semi-popular account of rearing muskellunge in a hatchery and the associated problems, such as providing enough food for the fry.

Morris, J., L. Morris and L. Witt 1972

The fishes of Nebraska. Nebraska Game Parks Comm., D-J Proj. F-4-R. 98 pp.

General characteristics (habitat, food, spawning, angling) of the family Esocidae are given. The muskellunge is said to be found infrequently in Nebraska. There is a colour illustration and a map of the distribution of the muskellunge.

Moseley, L. W. 1966

Fish inventory and evaluation. Findley Lake management report, 1956-1961. Ohio Div. Wildl., D-J proj. F-29-R-5, Job 7, PT3: 116-143.

Moselle, A. 1953

Hold that musky! Wisconsin Conserv. Bull. 18(6): 19-20.

Short note gives tips on angling for the muskellunge.

Moses, B. 1926

We caught a muskie. For. Stream, August: 460-461, 494-496.

Mosher, A. A. 1892

The mascalonge in Wisconsin waters. pp. 199-207. In Perry, W. A. et al. American game fishes their habits, habitat, and peculiarities; how, when, and where to angle for them. Chicago, New York, Rand, McNally. 865 pp.

Primarily angling notes.

Moyle, J. B. and C. R. Burrows 1954

Manual of instructions for lake survey. Minnesota Bur. Fish. Fish Res. Unit Spec. Publ. 1. 70 pp.

Mraz, D. F. 1962

Warm water fishery research. Delafield studies. Northern pike propagation studies. Sock ponds with northern pike fry, adult carp and muskie fingerlings. Wisconsin Conserv. Dep., D-J Proj. F-61-R-2, wk. pl. 12, Job A: 18-19.

Mueller, J. F. 1938 a

A new species of Trichodina (Ciliata) from the urinary tract of the muskalonge with a repartition of the genus. J. Parasitol. 24(3): 251-258.

Mueller, J. F. 1938 b

Parasitism in fishes of the Allegheny and Chemung areas. Sect. 9, pp. 214-235. In A biological survey of the Allegheny and Chemung watersheds. New York Conserv. Dep. Suppl. 27th Annu. Rep. (1937), Biol. Surv. 12. 287 pp.

Discussion of the various parasites that infect the muskellunge, including information on infecting stage, area of body affected, appearance of infected fish, and method of transmission. Includes original description of a parasite endemic to Esox masquinongy.

Muir, B. S. MS 1957

The cruising speed of the maskinonge (Esox masquinongy) in relation to water temperature. Univ. Toronto. $8 \mathrm{pp}$. Manuscript. 
Muir, B. S. 1960

Comparison of growth rates for native and hatchery-stocked populations of Esox masquinongy in Nogies Creek, Ontario. J. Fish. Res. Board Canada 17(6): 919-927.

Recent techniques have contributed to a more accurate determination of age by the scale method and a new growth curve for the maskinonge in Nogies Creek has been constructed. Hatchery fish, planted as fingerlings, show similar growth for 4 summers after which their growth rate rapidly falls away from that for the native fish. The hatchery fish require 3 years more than the native fish to reach legal length.

A reduction in the annual growth increment for tagged fish ranges from 25 percent (age IV) to 80 percent (age VI) of that attained by untagged fish.

No significant divergence in the length-weight relationship was observed in the slower growing hatchery fish. (Author's abstract)

Muir, B. S. MS 1961 a

Estimates of mortalities and population size for the Nogies Creek maskinonge (Esox masquinongy Mitchill). Univ. Toronto, Ph.D. thesis. $129 \mathrm{pp}$.

Muir, B. S. MS 1961 b

The Bobcaygeon sport fishery. Univ. Toronto. $12 \mathrm{pp}$. Manuscript.

Muir, B. S. 1963 a

Estimates of mortalities and population size for the Nogies Creek maskinonge (Esox masquinongy Mitchill). Int. Comm. Northwest Atlantic Fish., Woods Hole, Massachusetts, North Atlantic Fish Marking Symp. May, 1961, Spec. Publ. 4: 369-370.

Muir, B. S. 1963 b

Vital statistics of Esox masquinongy in Nogies Creek, Ontario. I. Tag loss, mortality due to tagging, and the estimate of exploitation. J. Fish. Res. Board Canada 20(5): 1213-1230.

A small population of muskellunge was exploited during a nine-year fishery using fixed nets. From 1952 to 1960,4000 muskellunge were handled, 2000 tagged and retumed to population. Tag loss estimates, total mortality estimates, and rate of recapture of tags were used to estimate exploitation.

Simultaneous tag and recapture data were used to develop a method of estimating coefficient of catchability for each age group.

Muir, B. S. 1964

Vital statistics of Esox masquinongy in Nogies Creek, Ontario. II. Population size, natural mortality, and the effect of fishing. J. Fish. Res. Board Canada 21(4): 727-746.

Several methods for estimating population size and natural mortality are used and evaluated for Nogies Creek muskellunge. Natural mortality increased with age. Fishing apparently had no effect on subsequent year-class production but heavy fishing removed large numbers of older fish. The removal of older fish resulted in increased catchability of younger fish.

Muir, B. S. and J. G. Sweet 1963

The survival, growth and movement of Esox masquinongy transplanted from Nogies Creek Sanctuary to public fishing waters. Univ. Toronto. $26 \mathrm{pp}$. Mimeograph.

Muir, B. S. and J. G. Sweet 1964

The survival, growth and movement of Esox masquinongy transplanted from Nogies Creek Sanctuary to public fishing waters. Can. Fish Cult. 32: 31-44.

Fom 1952 to 1958 muskellunge from Nogies Creek were tagged, measured, and transplanted into Pigeon and Sturgeon lakes, Ontario. A creel census of angler returns of tagged fish was conducted until 1960. Data obtained on growth, movement, and estimated exploitation are discussed and summarized in tables. The data indicate poor survival of sub-adult muskellunge transplanted but some success with older than age $\mathrm{V}$ fish.

Mullan, J. 1960

Walleyes, muskies and northerns. Massachusetts Wildl. 11(4): 17-19. 
Mussey, W. P. 1897

New muscallonge waters. For. Stream, July: 10.

Myers, I. K. 1915

My French River musky. Field Stream, June: 201-202, 204.

Nansen, C. 1973

The tiger muskie. Field Stream 78(6): 52, 53, 92, 94, 98.

Angling for muskellunge. Large colour photograph of the head, emphasizing jaws.

Nash, C.W. 1908

Checklist of the fishes of Ontario. pp. 7-122. In Vertebrates of Ontario. Dep. Educ., Toronto,

L. K. Cameron, King's Printer.

A description of the muskellunge, then known as the mascalonge, Lucius masquinongy.

Gives taxonomic characters, colour and markings, distribution, habits, and attributes.

Needham, J. G. 1920

Clean waters for New York State. Cornell Rural School Leafl. 13(4): 153-182.

General life history notes for students.

Nelson, E. W. 1884

A partial catalogue of the fishes of Illinois. Illinois Lab. Nat. Hist. (1876-1883) Bull. I: $33-52$.

Concise note on distribution of Esox nobilior in Illinois.

Nelson, G. J. 1969

Gill arches and the phylogeny of fishes, with notes on the classification of vertebrates. Am. Mus. Nat. Hist. Bull. 141(4): 475-552.

Netsch, M. F. and W. L. Turner 1954

Creel census and population studies. Tennessee Game Fish Comm., D-J Proj. F-2-R-5, Fin. $100 \mathrm{pp}$.

Nevin, J. 1901

The propagation of muskellunge in Wisconsin. Trans. Am. Fish. Soc. 30: 90-93.

Discusses reasons for decline of muskellunge in Wisconsin and describes the first attempts to culture it in Wisconsin.

Nigrelli, R. F. 1954

Tumors and other atypical cell growths in temperate freshwater fishes of North America. Trans. Am. Fish. Soc. (1953) 83: 262-296.

Black and white photograph shows a lymphosarcoma-like mass in muskellunge. The origin of "lymphosarcomas" in muskellunge said to be unknown.

Nikol'skii, G. V. 1961

Special ichthyology. 2nd ed. Israel Program Sci. Transl., Nat. Sci. Found. and Smithson. Inst. $538 \mathrm{pp}$.

Lists characteristics of the order (Esociformes) and discusses origin and taxonomic position. There is a chart showing growth rate of pike and muskellunge in various reservoirs.

Nikolyukin, N. I. 1963

Ein versuch zur Ausnutzung von hybriden zwischen Hausen und Sterlet als wirtschriftsobjekt in Stauseen. Ryb. Khoz. 39(2): 32-34.

Noland, W. E. 1951

The hydrography, fish, and turtle population of Lake Wingra. Trans. Wisconsin Acad. Sci. Arts Lett. 40(2): 5-58. 
Norman, J. R. 1966

A draft synopsis of the orders, families and genera of recent fishes and fish-like vertebrates.

London, Trustees of British Museum Natural History. 649 pp.

Synonymy of Esox mascalongus and Esox masquinongy.

Norris, T. 1864

The American angler's book. Philadelphia, Porter and Coates. 701 pp.

Norton, R. G. 1940

Propagation of maskinonge ("Maskalonge") at Chautauqua Hatchery, Bemus Point, N.Y. 7 pp. Mimeograph.

Odell, T. T. 1932

Lakes of the Oswegatchie and Black River systems. Sect. 3, pp. 94-119. In A biological survey of the Oswegatchie and Black River systems. New York Conserv. Dep. Suppl. 21st Annu. Rep. (1931), Biol. Surv. 6. 344 pp.

Odell, T. T. and W. C. Senning 1938

Lakes and ponds of the Allegheny and Chemung watersheds. Sect. 3, pp. 74-101. In A biological survey of the Allegheny and Chemung watersheds. New York Conserv. Dep. Suppl. 27th Annu. Rep. (1937), Biol. Surv. 12. 287 pp.

O'Donnell, D. J. 1945

Control of Hydrodictyon reticulatum in small ponds. Trans. Am. Fish. Soc. (1943) 73: 59-62.

A pond containing fingerling muskellunge became choked with the algae Hydrodictyon reticulatum. A serial treatment with copper sulphate was used to remove the algae without killing the muskellunge.

Oehmcke, A. A. 1949

Muskellunge fingerling culture. Production of the "muskie" in Wisconsin. Prog. Fish-Cult. 11(1): 3-18.

Research initiated on rearing techniques in Wisconsin resulted in the production of large numbers of fingerlings annually. Extensive data collected as a result of the muskellunge fingerling culture programme from 1942 to 1947 are given. Detailed descriptions of problems and methods used are presented under the following headings: egg fertilization and hatching, pond preparation, stocking and cropping, forage, and growth rate of muskellunge fingerlings. Text is accompanied by black and white photographs showing various aspects of the Woodruff Hatchery, as well as several tables.

Oehmcke, A. A. 1951

Muskellunge yearling culture and its application to lake management. Prog. Fish-Cult. 13(2): 63-70.

The problems resulting from stocking northern pike in native muskellunge waters are discussed. Because of the detrimental effect introduced pike were having on the muskellunge population, the Wisconsin Fish Management Division began removing pike and restocking muskellunge. Owing to the possibility that yearling muskellunge would have better survival when stocked, an experimental programme was set up to determine the practicability of rearing yearlings in ponds. Extensive data, including cost, accumulated from 1947 to 1949 given. Indicated potential if production could be increased.

Oehmcke, A. A. 1969

Muskellunge management in Wisconsin. Wisconsin Dep. Nat. Resour. Rep. 19. 18 pp.

Oehmcke, A. A. 1974

Muskellunge management in Wisconsin. Wisconsin Dep. Nat. Resour. Div. Fish Game Enforcement Bur. Fish Manage. Rep. 19. 
Oehmcke, A. A., L. Johnson, J. Klingbiel and C. Wistrom 1974

The Wisconsin muskellunge. lts life history, ecology, and management. Wisconsin Dep. Nat. Resour. Publ. 8-3600(74), 12 pp.

Classification, distribution, description, habits and habitat, reproduction, growth, population size, ecology, angling, economic value, and management of the Wisconsin muskellunge are covered.

Oehmcke, A. and K. Walker 1969

Temperature control in northern pike and muskellunge egg hatching. Wisconsin Dep. Nat. Resour. Fish Manage. Rep. Mimeograph.

Oehmcke, A., K. Walker and H. Laughlin 1969

The pond culture of muskellunge. Wisconsin Dep. Nat. Resour. Fish Manage. Rep. Mimeograph.

Orr, O. E. 1958

Fisheries inventory and investigations. Public power and irrigation reservoir investigations. Nebraska Game, Forestation Parks Comm., D-J Proj. F-4-R-4, wk. pl. 1, Job 6. 12 pp.

Osburn, R. C. 1901

The fishes of Ohio. Ohio Acad. Sci. Spec. Pap. 4. 104 pp.

Taxonomic description of the muskellunge, which is given the scientific name Lucius masquinongy (Mitchill). The author recognized two varieties, $L$. masquinongy var. masquinongy from Lake Erie and waters and L. Masquinongy ohiensis (Kirtland) from the Ohio River and its tributaries.

Osburn, R. C. and E. L. Wickliff 1930

A revised list of the fishes of Ohio. Ohio J. Sci. 30(3): 169-176.

Oughton, J. P. MS 1930 a

Game fish of the Trent Canal system. Ontario Fish. Res. Lab. 11 pp. Manuscript.

Oughton, J. P. MS 1930 b

Report of a trip up the Trent River system. Ontario Fish. Res. Lab. 8 pp. Manuscript.

Padgett, N. C. 1971

The tiger of northem lakes. Carte Blanche Mag., May/June: 35-36, 55.

Paetz, M. J., and J. S. Nelson 1970

The fishes of Alberta. Edmonton, Alberta, Queen's Printer. 282 pp.

Two species of Esocidae, northern pike and muskellunge, have been suspected to occur in Alberta but only the northem pike is said to be definitely known in the province.

Pageau, G. et L. Lévesque 1964

Les herbiers du lac Saint-Louis: composition, répartition et dynamisme en rapport avec, l'habitat du maskinongé. Québec Minist. Tourisme Chasse Pêche Serv. Faune Rapp. 3: 110 124.

A detailed description of the aquatic plants and habitat of Lake Saint-Louis, which is an example of a typical muskellunge habitat.

\section{Pageau, G. et L. Lévesque 1967}

Complexe des grands herbiers á maskinonge et á doré jaune du lac Saint-Louis, á la pointe sud-est de l'île Perrot. Québec Minist. Tourisme Chasse Pêche Serv. Faune Rapp. 4: 59-70.

Continuation of the previous study to determine the species of aquatic plants found in a typical muskellunge habitat. 
Pageau, G., Y. Gravel and L. Lévesque 1971

The ichthyofauna and flora of Lake St. Louis on the St. Lawrence River near Montreal, Quebec: general features and recent changes. Int. Assoc. Great Lakes Res. Proc. 14th Conf.: 79-89.

Although Esox masquinongy is present in Lake St. Louis, pollution and eutrophication are probably responsible for its gradual decrease.

Paladino, F. V. 1976

The effect of arsenic on the thermal tolerance and survival of newly hatched muskellunge fry. New York State Univ. Buffalo, M.S. thesis. 35 pp.

Papier, D. and R. Reithmiller 1958

Muskellunge at Kincaid fish farm - some questions and answers regarding the Ohio muskellunge. Ohio Div. Wildl. 7 pp. Mimeograph.

Paquet, G. 1972

Inventaire biologique et étude physique sommaires de la rivière Nord-Ouest et de quelques-uns de ses affluents, comté de Montmagny, 1967. Québec Minist. Tourisme Chasse Pêche Serv. Faune Rapp. 6: 237-255.

Recommends the introduction of muskellunge into the river.

Parker, B. 1966

Operation fish research. Tennessee Game Fish Comm., D-J Proj. F-27-R: 10-11.

Parks, G. H. 1920

The fall of the king. Field Stream, May.

Parsons, J. W. 1955 a

Cumberland Plateau stream management and fertilization study. Fish populations and migration studies. Tennessee Game Fish Comm. Quart. Prog. Rep., D-J Proj. F-7-R-1, wk. pl. 2, Job A, QU3: 2-5.

Parsons, J. W. 1955 b

Cumberland Plateau stream management and fertilization study. Fish population and migration studies. Tennessee Game Fish Comm. Quart. Prog. Rep., D-J Proj. F-7-R-2, Job 2, QU1: 3-5, $8-14$.

Parsons, J. W. 1958

The study and management of muskellunge in Tennessee. Tennessee Game Fish Comm. 23 pp.

Extensive study of the problems associated with the muskellunge fishery in Tennessee and suggested possible methods to improve it.

Parsons, J. W. 1959

Muskellunge in Tennessee streams. Trans. Am. Fish. Soc. 88(2): 136-140.

Muskellunge (Esox masquinongy) are known to inhabit 169 miles of rocky and fast-flowing streams on the Cumerland Plateau in East-Central Tennessee. These waters are usually clear (turbidity less than $5 \mathrm{ppm}$ ) and slightly acid. Muskellunge in Tennessee streams grow an average of 5.8 inches $(147 \mathrm{~mm})$ per year but few fish live beyond 6 years of age. Male fish mature when about 22 inches $(559 \mathrm{~mm})$ long and 3 years old; females mature when about 25 inches $(635 \mathrm{~mm})$ long and 3 or 4 years old. Muskellunge spawn in April when water temperatures are near $50^{\circ} \mathrm{F}$. Young fish are found in only 15 percent of the total habitat distance. Management of the muskellunge streams in Tennessee appears to be necessary to maintain the presently small muskellunge fishery. (Author's abstract)

Pasko, D. G. 1949

Forty-three tons of inuskellunge. New York Conserv. Bull. 4(1): 18. 
Patrick, B. and R. Haas 1971

Fin pulling as a technique for marking nuskellunge fingerlings. Prog. Fish-Cult. 33(2): 116118.

A permanent mark was made on Great Lakes muskellunge (Esox masquinongy) fingerlings by extracting the left pelvic fin and a portion of the left side of the pelvic girdle. The fins were pulled on 989 fish of which 2 died during the handling period. There was a 90 per cent return of the marked fish from a 1.3-ha pond. The difference in percentage loss between marked and unmarked fish was only 4.8 per cent and the growth rate was nearly the same for the two groups. This marking technique is encouraging and the authors hope to study the survival of marked fish in the wild.

Patterson, D. L. 1953

The walleye population in Escambia Lake, Vilas County, Wisconsin. Trans. Am. Fish. Soc. (1952) 82: $3+41$.

Esox masquinongy was one of the species of fish found in Escambia Lake.

Pelton, J. Z. 1951

Muskies in Ohio. Part 1. Ohio Conserv. Bull. 15(2): 8, 9, 30.

Pelton, J. Z. 1956

History of the Ohio muskellunge in muskellunge management in Ohio - its history, problems, and goals. Ohio Div. Wildl. 2 pp. Mimeograph.

Penhale, B. 1961

The land of the moody monster. Trent Valley Vacation Guide 3(1): 22-23, 51.

Penney, L. 1966

Mean total lengths and calendar duration of spawning of the adult muskellunge (Esox masquinong.v) in Muskie Lake. Ontario Dep. Lands For. Swastika District (1963-1965). 6 pp. Mimeograph.

Measurements and calendar duration of spawning run of muskellunge from Muskie Lake are examined and discussed.

\section{Penney, L. 1968}

Capture and planting of adult muskellunge, Sioux Lookout. Ontario Dep. Lands For. Rep. 8 pp. Mimeograph.

While on their spawning run, 60 adult muskellunge were captured, sexed, measured, tagged, and transported to Sturgeon Lake, Ontario.

Peterson, K. D. 1890

After muskallonge and wall-eyed pike. Outing Mag., October: 17-20.

Pfitzer, D. W. 1952

Investigation of waters below storage reservoirs. Chemical and physical studies of tailwaters. Tennessee Game Fish Comm. Quart. Prog. Rep., D-J Proj. F-1-R-1, wk. pl. 1, Job A, Job C.QU2. 16 pp.

Pfitzer, D. W. 1954

Investigations of waters below storage reservoirs. Tennessee Game Fish Comm., D-j Proj. F-1.R-4, Fin. 275 pp.

Pflieger, W. L. 1971

A distributional study of Missouri fishes. Univ. Kansas Publ., Mus. Nat. Hist. 20(3): 225-570.

The muskellunge is not native to Missouri, but its occurrence as fossils southwest of Missouri suggests that it was present there during the Pleistocene. The muskellunge has been stocked on an experimental basis. 
Pflieger, W. L. 1975

The fishes of Missouri. Missouri Dep. Conserv. 343 pp.

Contains key to families and key to species. Short note discusses the muskellunge under the following headings: description, distribution and habitat, habits and life history, importance, and angling.

Phillips, R. 1974 a

A domestic muskellunge broodstock. Morehead, Kentucky, Proc. 6th Interstate Muskellunge Workshop, September 25-26: 64-65.

Outlines maintenance of two generations of muskellunge broodstock in Valley City National Hatchery.

Phillips, R. 1974 b

Dry diet trials. Morehead, Kentucky, Proc. 6th Interstate Muskellunge Workshop, September 25-26: 10-13. Mimeograph.

Outlines method and result of rearing muskellunge, northern pike, and walleye on a dry diet.

Phillips, R. 1975

Muskellunge dry diet feeding at Valley City. La Crosse, Wisconsin, Proc. 7th Interstate Musky Workshop, September 30-October 1: 34-35. Mimeograph.

Briefly outlines number of eggs taken, mortality, feeding of combined plankton and dry pellets, and disease.

Phillips. R. and W. J, Graveen 1973

A domestic muskellunge broodstock. Prog. Fish-Cult. 35(3): 176-178.

Short summary of investigation to determine success of maintaining a muskellunge broodstock. Growth of broodstock was roughly equal to that of wild populations for first three years but then declined. When females reached maturity, spawning stimuli were tested, but females allowed to mature without stimuli spawned successfully. Spawning data contained in tables.

Pierson, E. E. 1913

In the haunt of the muskellunge. For. Stream, May.

Pinkowski, B. 1961

Muskie fever. New York, A. S. Bames. 127 pp.

Poole, E. G. 1937

Muskalonge. In Schrenkeisen, R. M., ed. Fishing for bass, muskalonge, pike and pan fishes. Garden City, Doubleday, Doran. 181 pp.

Porter, E. C. 1925

The big muskie of French River. For. Stream, August: 465-466, 500-501.

Potvin, C. L. G. et A. Courtemanche 1968

Découverte d'une population indigène de maskinongé a l'est du Saint-Maurice. Ann. ACFAS (Assoc. Can. Fr. Av. Sci.) 35: 92.

Pratt, K. 1975

Rearing tiger muskies on artificial diets. La Crosse, Wisconsin, Proc. 7th 1nterstate Musky Workshop, September 30-October 1: 25-33. Mimeograph.

Discusses rearing of the hybrid Esox masquinongy $\times$ Esox lucius at the Wolf Lake Hatchery, Michigan, 1975. Artificial food was used during the 90-day rearing programme with good success.

Observation on survival rates, weight gains, water quality, behaviour, rearing problems and successes, and techniques are presented. 
Préfontaine, G. et J.-P. Cuerrier 1941

Quelques frayères présumées de l'achigan, du doré, du maskinongé, de la perchaude et de la barbotte dans la région de Montréal. Québec Minist. Chasse Pêche Rapp. Stn. Biol. Montréal Stn. Biol. Parc Laurentides (1941). Fascicule 1: 133-157.

Presumed spawning grounds and map showing locations where specimens were caught in Lac Saint-Louis.

Preuss, R. 1965

The muskellunge. Sports Recreation, July/August: 41 .

Prévost, G. 1951

La pisciculture de Lachine. Carnets Zool. 12(4): 172-175.

Brief note on the culture of maskinonge.

Prévost, G..ed. 1961

Contribution de la Station Piscicole de Lachine à l'étude du maskinongé. Québec Minist. Pêch. Pêche Suppl. Trimestriel J. Bord. 55 pp. [In French and English]

Contains articles of varying lengths written by several authors. They mainly discuss tech. niques of raising muskellunge in a hatchery, data accumulated, and problems encountered.

Priegel, G. R. 1967

Statewide fishery research. Lake Winnebago studies. Evaluation of dredged channels, lagoons and marinas as fish habitat. Wisconsin Conserv. Dep., D-J Proj. F-83-R-2, wk. pl. 5, Job E, Fin.: $17-35$.

Prince, E. E. 1898

On the Esocidae (or Luciidae) of Canada. British Assoc. Adv. Sci. (1897) Rep. Meet. 67:688.

Ray counts, length, and lateral line scales for a specimen of muskellunge (Esox nobilior) tabled. Lower half of both the cheek and gill cover said to be scaleless.

Prince, E. E. 1900

Fish culture in Canada. Trans. Ottawa Lit. Sci. Soc.: 163-182.

Outlines the history of fish culture in Canada. Mentions that the culture of muskellunge was not done because of expense and difficulty in hatching eggs.

Prince, E. E. 1901

The vernacular names of fishes. Rep. 2, pp. 12-23. In Special appended reports 1900. Ottawa, Gov. Printing Bur. 35 pp.

"Thus the name maskinongé, commonly but very erroneously spelt muskellunge or mascalonge in the United States is really an Indian name, the Chippewa name for pike being 'Kenosha' and the prefix Mis or Mas means large or great, so that the Maskenosha or Maskinonge (corrupted into Maskinonge) is really a large deformed pike."

Prince, E. E. 1909

Special report on the fish and fisheries of Manitoba. Ottawa, Gov. Printing Bur. 8 pp.

Lucius masquinongy is listed as one of the species present in Manitoba and is said to be present there possibly owing to the nature of the eggs.

Prince, E. E. 1912

The propagation and planting of predaceous fish. Ottawa, Gov. Printing Bur. Spec. Rep. 2: 16-30.

In summary it was said that muskellunge, pike, pickerel, and perch can coexist in the same waters.

Quarles, J. V., Jr. no date

Maskalonge fishing. How to find, catch and cook the "water tiger". Outing Mag.: 112-118. 
Radforth, I. MS 1941

Some considerations on the distribution of fishes in Ontario. Univ. Toronto, M.A. thesis. 119 pp.

See Radforth (1944).

Radforth, I. 1944

Some considerations on the distribution of fishes in Ontario. R. Ontario Mus. Zool. Contrib. 25. $116 \mathrm{pp}$.

Map and note on distribution of Esox masquinongy and notes on three supposed subspecies attempt to explain that derivation of the subspecies began in the glacial period.

Radonski, G. 1964

Muskellunge fry mortality at the Woodruff hatchery in 1963. Wisconsin Conserv. Dep. Fish Manage. Div. Northeast Area lnvest. Memo 8.

Radonski, G. 1965

Muskellunge fry mortality at the Woodruff hatchery in 1964 . Wisconsin Conserv. Dep. Fish Manage. Div. Northeast Area Invest. Memo 12.

Rainey, D. 1968

Musky of yesteryear. Tennessee Conserv. 34(7): 11-12.

Ramsell, L. A. 1976 a

Here's how and why you should release your muskies. Fins Feathers, August: 14-16, 49-50.

Ramsell, L. A. 1976 b

For more muskie action, master the figure eight. Fins Feathers, June: 43-44.

Raney, E. C. MS 1941

Report on the Chautauqua Lake muskalonge situation. New York Dep. Environ. Conserv. Rep. 25 pp. Manuscript.

Raney, E. C. 1955

Natural hybrids between two species of pickerel (Esox) in Stearns Pond, Massachusetts. pp. 405-420. In Supplement to fisheries report for some central, eastern, and western Massachusetts lakes, ponds, and reservoirs, 1951-1952. Massachusetts Bur. Wildl. Res. Manage. Div. Fish Game. 447 pp.

\section{Raney, E. C. and D. A. Webster 1942}

The spring migration of the common white sucker, Catostomus $c$. commersonnii (Lacépède), in Skaneateles Lake inlet, New York. Copeia 1942(3): 139-148.

Mentions that much of the information presented in this paper on the common white sucker may be useful in connection with the pond culture of "muskalonge".

Rathburn, R. and W. Wakeham 1897

Preservation of the fisheries in the waters contiguous to Canada and the United States. U.S. Joint Comm. Rep. House Doc. 315, 54th Congr.: 14-178.

Rathom, J. R. 1902

A fight with a muskallonge. Scribner's Mag., May: 534-536.

Reddick, D. V. 1944

Stony's "Moby Dick". Field Stream, February: 32-33, 60-62.

Reddick, D. W. 1962 a

Ma-kee. The life and death of a muskellunge. Toronto, McClelland and Stewart. $206 \mathrm{pp}$.

Written like a story book about a wildlife fictional hero. Although highly descriptive, it is very anthropomorphic. Often the accuracy of statements is questionable. 
Reddick, D. $1962 \mathrm{~b}$

The mighty muskellunge. New York, Dodd, Mead. 206 pp.

Reece, M. 1963

Fish and fishing. A Better Homes and Gardens Book, New York, Des Moines, Meredith Press. 224 pp.

This book is printarily of interest to the outdoorsman and angler. General notes on biology, distribution, and habits of the nuskellunge are given with hints to capturing them. There are colour drawings showing the variable markings, barted, spotted and clear, and one of the pike-muskellunge hybrid. (pp. 142-145)

Reithmiller, R. H. 1958

The Ohio muskellunge program 1948-1958. Ohio Div. Wildl. Dep. Nat. Resour. 10 pp. Mimeograph.

Rhead, L. 1906

The Chautauqua maskinonge. For. Stream, November.

Rhead, L. 1910

Casting for muskellunge. Outing Mag., June: $341-344$.

Rhead, L. 1917

My "fool hooked" muskie experience. For. Stream, October: 475, 509.

Rhead, L. 1923

The mascalonge. For. Stream 93(9): 483-485, 544.

Richards, G. 1968

Stream fishing for musky. Fur-Fish-Game, June: 16-17, 43-45.

Richardson, J. 1836

The Fish. Part 3. 4 vols. Fauna Boreali-Americana; or the zoology of the northern parts of British America: containing descriptions of the objects of natural history collected on the late northern land expeditions under command of Sir John Franklin, R.N. London, R. Bently.

Description, including colour and markings, fin rays, dimensions, and other distinguishing features. (pp. 127-128)

Richardson, L. R. 1938

A note on the variation in squamation of the cheek operculum in two etheostomid fishes from Quebec. Copeia 1938(3): 126-128.

Esox masquinongy, among others, is said to be common in waters of the St. Lawrence River but does not penetrate the waters of the highland formations.

Richey, D. 1970

Backyard muskies for Detroit anglers. Fish. Hunting Guide, April: 5.

Richey, D. 1975

Make mine muskellunge. Cord Sportfacts Fish. Annu.

Ricker, W. 1947

Muskellunge. Ohio Conserv. Bull. 11: 13.

Ricker, W. 1964

The need for a habitat. Chap. 4, pp. 29-38. In Dymond, J. R., ed. Fish and wildlife a memorial to W. J. K. Harkness. Toronto, Longmans Canada. 214 pp.

States that the better, larger rivers support stocks of muskellunge. 
Riddle, J. W., Jr. MS 1975

Status of the native muskellunge, Esox masquinongy ohioensis, of the Cumberland Plateau, Tennessee. Tennessee Technological Univ., M.Sc. thesis. 70 pp.

Muskellunge populations were investigated in the watersheds of the Big South Fork of the Cumberland River (that portion within Tennessee) and the Emory River (a part of the Tennessee River system). Muskellunge were collected or reported in both drainages in Clear Fork River, Crooked Creek, Daddy's Creek, Clear Creek, Rock Creek, White Creek, Emory River, and the lower portion of the Obed River. Pollution from surface mined coal appeared to be causing the decline of muskellunge in this area. Species composition showed abundant forage fishes in all streams sampled. Limited populations of native muskellunge remain in the areas where habitat remains suitable. Management recommendations are made herein. (Author's abstract)

\section{Ritchie, R. 1953}

Description of lymphosarcoma of muskellunge. 2 pp. Mimeograph.

Lymphosarcoma is defined and described. It has been found in muskellunge taken from Pigeon Lake, Stoney Lake, Sturgeon Lake, and Lake Scugog, Ontario. There is a black and white photograph showing the presence of lymphosarcoma in a muskellunge.

Roach, L. S. 1947

Muskellunge. Ohio Conserv. Bull. 11(12): 13.

Roach, L. S. 1949

In fishing circles. Ohio Conserv. Bull. 13(10): 12.

Roberts, K. R. 1964

Fish inventory and evaluation of muskellunge stocking. Ohio Div. Wildl., D-J Proj. F-29-R-3, Job 3.42 pp.

Robertson, J. 1969

Observations on the artificial propagation of Great Lakes muskellunge in Michigan 1968. Mattawan, Michigan, Wolf Lake Fish Hatchery, January: 5. Pamphlet.

Robertson, J. 1972

The artificial propagation of warm-water game fish - Part $1-$ muskellunge. Michigan Dep. Nat. Resour. Mimeograph.

Robinson, B. C. 1920 a

The king of our inland waters. For. Stream, October: 543-544, 564-565.

Robinson, B. C. 1920 b

The monarch of the painted streams. Field Stream, October: 572-573.

Robinson, B. C. 1923

"Where you goin' to get your musky?'” For. Stream, August: 444.

Robinson, B. C. 1925

Muskellunge fishing. New York, London, D. Appelton. 116 pp.

An illustrated book on the muskellunge, giving primarily angling information.

Robinson, B. C. 1928

When muskies are king! For. Stream, July: 402-403, 446.

Robinson, B. C. 1945

Muskie methods. Field Stream, October: 108, 110-112.

Robinson, B. C. 1948

Muskies in the hills. Field Stream, January: 24-25, 96-97. 
Robinson, B. C. 1959

'Shuttle Buggin' for outboard muskies. Fur-Fish-Game, July: 20-23.

Robinson, B. C. 1963 a

Spawning traits of "Big Mama"s". Fur-Fish-Game, July: 20-22.

Robinson, B. C. 1963 b

Fall fishing days. Fur-Fish-Game, September: 36-38.

Robinson, D. W. 1959

Fishery investigations of selected tributaries of the Upper Ohio River. Age and growth studies. West Virginia Div. Game Fish, D-J Proj. F-6-R-3, Job 3. 12 pp.

Robinson, D. W. 1964

Stream and lake survey. Stream improvement attempts on three Northwestern West Virginia warm-water streams. West Virginia Div. Game Fish, D-J Proj. F-10-R-5, Job 3, PTA. 45 pp.

Ross, R. D. 1959

Drainage evolution and distribution problems of the fishes of the New (Upper Kanawha) River system in Virginia. Key to the identification of fishes. Part 4. Virginia Agric. Exp. Stn., Virginia Polytech. Inst. Tech. Bull. 146. 27 pp.

Refers only to Esox masquinongy ohiensis and not to any other so-called subspecies. Given in key and table of occurrence.

Rostlund, E. 1952

Freshwater fish and fishing in native North America. Vol. 9. Univ. California Publ. Geogr. $313 \mathrm{pp}$.

Historical and recent importance of the family Esocidae as a food fish is discussed. There is a map showing range of Esox masquinongy and Esox masquinongy ohiensis.

Roussow, G. 1953

Rearing and pathology of maskinonge, yellow pike, perch and carp and other works. Quebec Biol. Bur. Rep. (1951-1952) 9: 377-383.

Roussow, G. 1961

Quelques anomalies et déformations chez les poissons dans nos aquariums. Québec Minist. Chasse Pêch. J. Bord: 659-662.

Deformed muskellunge are described. Possible causes of these conditions are given. Black and white photographs.

St. John, L. 1920

Three muskieteers. Field Stream, November: 667-668, 706-707.

Samuels, H. J. 1969

The muskellunge. Annu. Midwest Fish. Guide: 36.

Sanderson, C. H. 1969

Results of feeding daphnia to muskellunge over a prolonged period. Benner Spring Fish Res. Stn., Notes for Fish Culturists. 4 pp.

Results of an experiment to determine effect on survival and growth of muskellunge if they were not advanced beyond a diet of zooplankton.

Sanderson, C. H. 1974

Artificial diets for esocids and walleye culture. Morehead, Kentucky, Proc. 6th Interstate Muskellunge Workshop. September 25-26: 14-18. Mimeograph.

Rearing of hatchery fish on a dry diet was found to be promising, although the survival rates for muskellunge were low. 
Sanderson, C. H. and Z. Bean 1974

Tiger muskellunge culture. Artificial diet - concrete rearing units. Morehead, Kentucky, Proc. 6th Interstate Muskellunge Workshop, September 25-226: 19-20. Mimeograph.

Discusses project to determine practicability of training tiger muskellunge to accept pellet food. Data indicate some success.

Sandys, E. W. 1889

A memory of the Thousand lslands. Outing Mag., July: 270-275.

Sandys, E. W. 1895

A Rondeau muskallonge. Outing Mag., October: 135-138.

Sandys, E. W. 1902

A matter of mascalonge. Outing Mag., August: 576-582.

Sauve, J. and J. Fowler MS 1961

The spawning habits of the maskinonge. Montreal Anglers and Hunters. $8 \mathrm{pp}$. Manuscript.

Since the fishing season is usually not opened until after the fish have spawned, a study was undertaken to determine the latest spawning time of the muskellunge. Apparently the three subspecies have different requirements (temperature). Also it is clear that different bodies of water reach the preferred spawning temperature at different times. The St. Lawrence River does not reach the maximum temperature until mid-June, whereas Lake Donaldson does so in May. Temperature $\times$ date graphs show spawning periods of the muskellunge in (1) St. Lawrence River and (2) Lake Donaldson.

Schaldach, W. J. 1943

Of muskies and men. Field Stream, July: $39,58-59$.

Schara, R. 1969

Best lakes for Minnesota musky. Fish. Hunting Guide, August: 24.

Scharf, J. A. 1966 a

Figure 8's in a cabbage patch. Fur-Fish-Game, September: 7-9, 39-40.

Scharf, J. A. 1966 b

Musky fever strikes. Midwest Outdoorsman, February: 22-23, 51-54.

Schloemer, C. L. 1936

The growth of the muskellunge, Esox masquinongy immaculatus (Garrard), in various lakes and drainage areas of northern Wisconsin. Copeia 1936(4): 185-193.

This study was based on the scales and length data of 351 muskellunge taken from 70 different Wisconsin lakes over an eight-year period.

A histogram, which shows the distribution of the muskellunge grouped into age groups, is discussed. Rate of growth is exemplified by growth and increment curves.

Calculated standard lengths attained by various age groups of muskellunge at the end of each year of life and the number of individuals comprising each age group are given in a table.

The differential growth rates in various lakes in the state are discussed. On the basis of the lakes that seem to produce the largest muskellunge, a stocking policy is outlined.

Schloemer, C. L. 1938

A second report on the growth of the muskellunge, Esox masquinongy immaculatus (Garrard), in Wisconsin waters. Trans. Wisconsin Acad. Sci. Arts Lett. 31: 507-512.

Schmitz, W. R. and R. E. Hetfeld 1965

Predation by introduced muskellunge on perch and bass, 11: years 8-9. Trans. Wisconsin Acad. Sci. Arts Lett. 54: 273-282. 
Population changes were measured and estimated eight and nine years after introduction of young-of-the-year muskellunge into lakes containing perch and bass. Follow-up to study described by Gammon and Hasler (1965).

Schneberger, E. 1946

The muskellunge. Wisconsin Conserv. Bull., December.

Schoettger, R. A. and E. W. Steucke, Jr. 1970

Quinaldine and MS-222 as spawning aids for northern pike, muskellunge, and walleyes. Prog. Fish-Cult. 32(4): 199-201.

The efficacy of quinaldine and MS-222 as spawning aids for northern pike (Esox lucius), muskellunge ( $E$. musquinongy), and walleyes (Stizostedion vitreum) was documented under field conditions. Concentrations of 10 to $20 \mathrm{ppm}$ of quinaldine, or 100 to $150 \mathrm{ppm}$ of MS-222, were effective on the three species. Both anesthetics act rapidly. Quinaldine does not block reflex activity, but fish tolerate relatively long exposures. The reverse occurs in fish anesthetized with MS-222. (Authors" abstract)

Scholl, R. L. 1966

Lake Erie fish research. Lake Erie fish population gill netting survey. Ohio Div. Wildl., D-J Proj. F-35-R-4, Job t. 36 pp.

Schrenkeisen, R. M. 1963

Field book of fresh-water fishes of North America north of Mexico. New York, G. P. Putnam's Sons. $312 \mathrm{pp}$.

Schrouder, J. 1973

Muskellunge management in Michigan. Michigan Dep. Nat. Resour. Fish Div. Tech. Rep. 73-31. $21 \mathrm{pp}$.

Schwartz, F. J. 1972

World literature to fish hybrids with an analysis by family, species, and hybrid. Publ. Gulf Coast Res. Lab. Mus. 3. 328 pp.

A bibliography of fish hybrids. References to Esox masquinongy hybrids are included in this bibliography.

Scotford, F. E. 1908

How to catch mascalonge - perhaps. Outing Mag., October: 125-127.

Scott, D. P. 1964

Thermal resistance of pike (Esox lucius L.) and muskellunge (E. masquinongy Mitchill) and their $F_{1}$ hybrid. J. Fish. Res. Board Canada 21(5): 1043-1049.

Comparison of thermal resistance of pike, muskellunge, and their $F_{1}$ hybrids indicated close similarity between the two species. Hybrid vigour was expressed in the greater thermal resistance of the progeny at average acclimation and test temperatures.

Scott, G. C. 1875

Fishing in American waters. New ed. New York. 539 pp.

Scott, J. D. 1972

Fire in the water. Sports Afield, September: 52-53, 90-92, 94.

Scott, W. B. 1958

A checklist of the freshwater fishes of Canada and Alaska. R. Ontario Mus. Div. Zool. Palaeontol. $30 \mathrm{pp}$.

Esox masquinongy is in the checklist. 
Scott, W. B. 1963

A review of the changes in the fish fauna of Ontario. Trans. R. Can. Inst. 34(2): 111-125. Esox masquinongy is included in list of Ontario fishes.

Scott, W. B. 1967

Freshwater fishes of eastern Canada. 2nd ed. Univ. Toronto Press. 137 pp.

Notes on other common names, distinguishing features, size, occurrence, life history and habits, and food, and author's comments.

Scott, W. B. and E. J. Crossman 1967

Provisional checklist of Canadian freshwater fishes. R. Ontario Mus. Dep. Ichthyol. Herpetol. Inf. Leafl. 39 pp. Mimeograph.

Esox masquinongy is included in list of fishes in Atlantic watershed basin and in checklist.

Scott, W. B. and E. J. Crossman 1969

A list of Ontario fishes. R. Ontario Mus. Dep. Ichthyol. Herpetol. Inf. Leafl. 7 pp. Mimeograph.

Esox masquinongy is listed.

Scott, W. B. et E. J. Crossman 1974

Poissons d'eau douce du Canada. Off. Rech. Pêch. Canada Bull. 184. 1026 pp.

Scott, W. B. and E. J. Crossman 1975

Freshwater fishes of Canada. Reprint ed. Fish. Res. Board Canada Bull. 184. 966 pp.

The write-up on the muskellunge ( 7 pages) summarizes the available literature under headings of description (detailed), colour, systematic notes, distribution, biology, relation to man, and nomenclature (Canadian synonymy and etymology). Good black and white line drawing.

Seaborn, E. 1937

Variations in the maskinonge in the Sauble River, Ontario. Copeia 1937(4): 237-238.

The 25 muskellunge that the author had caught in the Sauble River seem to fall into three categories; "barred type", "spotted type", and "green maskinonge". Colour and markings are described and certain meristics are given (lateral line scales, dorsal rays, anal rays, branchiostegal rays, and cheek scalation) in a table.

The author points out that these three forms have been regarded as subspecies and sometimes species (ohioensis, masquinongy, immaculatus).

Seagers, C. no date a

Making muskies. Muskalonge, the inside on the outdoors. New York Conservationist Reprint 13. 2 pp.

Muskellunge were collected from Chautauqua Lake and stripped. Describes hatchery operations and includes muskellunge hatching and rearing schedule.

Seagers, $C$. no date $b$

Muskalonge. The eating machine. New York Conservationist Reprint 13.2 pp.

Essentially a cartoon showing how muskellunge are cultured in a hatchery.

Seaman, E. A. 1948

Fish, fish management, and fishing in West Virginia. West Virginia Conserv. Comm. Div. Fish Manage. 34 pp.

There are both a map and a chart showing where the principal fish can be found.

Seaman, R. 1956

Hook, line, and sinker. Harrisburg, Pennsylvania, Stackpole. 246 pp. 
Séguin, L.-R. MS 1950

Élevage du maskinongé à Bemus Point, N.Y. State Fish Hatchery. 24 pp. Manuscrit.

Detailed description of the culture of muskellunge at Bemus Point, from capturing the parent stock to planting fry. Includes all the details.

Séguin, L.-R. MS 1951

L'élevage du maskinongé. 8 pp. Manuscrit.

See published version. Séguin (1952 a).

Séguin, L.-R. 1952 a

L'élevage du maskinongé. Carnets Zool. 12(1): $32-41$.

Discusses the biology of the muskellunge under the following headings: habitat, feeding, growth, reproduction, predators, and protection. This is followed by a detailed description of the culture under these headings: reproduction, artificial fertilization, incubation, raising alevins in troughs and then ponds, feeding, growth, cost of production, and planting.

Séguin, L.-R. 1952 b

The raising of maskinonge. Traduction de "L'élevage du maskinongé. Carnets Zool. 12(1): $32-41 . " 8$ pp. Mimeograph.

See Séguin (1952 a).

Semotok, M. J. and L. Penney 1966

Operation musky. Ontario Fish Wildl. Rev. 5(4): 17-18.

Sexton, A. D. MS 1963

Investigations of the antigenic relationships of the Esocidae and two species of Percidae. Pennsylvania State Univ., Ph.D. thesis. 55 pp.

A serological comparison to determine taxonomic relationships.

Shaw, D. 1958

New world's record muskie. Field Stream, May: 87, 106, 108-109.

Shea, P. 1971

Ontario's gateway to tackle-busting muskies or musky fever at Eagle Lake. Fish. Hunting Guide, August: 8-9.

Sheppard, W. 1968

Angler harvest of Chautauqua Lake muskalonge. New York State Fish News, April, 26: 7-8.

Shoemaker, M. E. 1942

Fresh water fishing. A fisherman's manual. Garden City, Doubleday, Doran. 218 pp.

Shuter, B. J. MS 1971

The largemouth bass population of Nogies Creek, Ontario. Univ. Toronto, M.Sc. thesis. 161 pp.

Merely mentions muskellunge as one of the species present in Nogies Creek.

Simard, A. MS 1966

Recherches sur les relations longueur-poids et sur la croissance du maskinongé, Esox masquinongy (Mitchill), dans quatre lacs du Québec. Univ. Montréal, M.Sc. thesis. $57 \mathrm{pp}$.

Much of the information in this thesis is covered by Simard and Magnin (1968). However, this manuscript gives short statements on taxonomy of esocids, distribution of Esox masquinongy, and summary of published works on age and growth of the muskellunge in (a) the United States and Ontario and (b) Quebec. 
Simard, A. and E. Magnin 1968

Age and growth of muskellunge, Esox masquinongy, in four lakes in Quebec. (Âge et croissance du maskinongé, Esox masquinongy, dans quatre lacs du Québec). J. Fish. Res. Board Canada 25(9): 1831-1842.

Specimens were taken from two lakes where maskinonge is indigenous: Lake Saint-Francois (188 specimens) and Lake Saint-Louis (109 specimens), and from two others where it was introduced: Lake Saint-Joseph (44 specimens) and Lake Ouareau (12 specimens). The ages were determined from scale reading. Growth in length and in weight was identical for males and females from lakes Saint-Francois and Saint-Louis and there was no difference in growth observed in these same two lakes. Growth, however, was very different in lakes Saint-Joseph and Ouareau during their 11 th summer for instance, maskinonges from lakes Saint-Francois and Saint-Louis measured $1112 \mathrm{~mm}$, and weighed $10,511 \mathrm{~g}$ whereas those from Lake SaintJoseph measured $1024 \mathrm{~mm}$ and weighed $8854 \mathrm{~g}$ and those from Lake Ouareau measured 914 $\mathrm{mm}$ and weighed $5669 \mathrm{~g}$. Our results are compared with those in the literature. (Authors' abstract)

Sisley, N. 1971

Allegheny "frost line" muskies. Fish. Hunting Guide, November: 28-29.

Slastenenko, E. P. 1956

Una Lista de Los Hibridos Naturales de Peces del Mundo. Rev. Soc. Mex. Hist. Nat. 17(1/4): 63-84.

Slastenenko, E. P. 1957

A list of natural fish hybrids of the world. Hidrobiologi ser. B, 4(2-3): 76-97.

Slastenenko, E. P. 1958

The freshwater fishes of Canada. Toronto, Kiev Printers. 385 pp.

There is a black and white illustration depicting the muskellunge, along with a note that discusses synonymy, identification, Canadian distribution, habitat, spawning, and feeding. (pp. 143-145)

Slone, T. H. 1918

Angling for Minnesota muskellunge. For. Stream, December: 702-703.

Small, H. B. 1865

The animals of North America. Series 2. Fresh-water fish. Montreal, M. Longmoore. 72 pp.

Primarily an account of angling for the muskellunge, although colour, markings, and habits are briefly described. Emphasizes the large size that the muskellunge can attain.

Small, H. B. 1866

The Canadian handbook and tourists guide. Montreal, M. Longmoore.

Small, H. B. 1883

Fishes of the Ottawa District. Trans. Ottawa Field Nat. Club (1882-1883) 4: 31-49.

Esox Nobilior - maskinongé is listed.

Smith, C. L. 1954

Pleistocene fishes of the Berends fauna of Beaver County, Oklahoma. Copeia 1954(4): 282289.

Describes three teeth and a fragment of a fourth from muskellunge.

Smith, C. L. 1958

Additional Pleistocene fishes from Kansas and Oklahoma. Copeia 1958(3): 176-180.

Esox masquinongy had been found in Berends fossil locality. 
Smith, C. L. 1962

Some Pliocene fishes from Kansas, Oklahoma, and Nebraska. Copeia 1962(3): 505-520.

Mentions range of Esox masquinongy.

Smith, G. R. 1963

A late lllinoian fish fauna from southwestern Kansas and its climatic significance. Copeia 1963(2): 278-285.

Describes one fossil lateral jaw tooth of the muskellunge and gives present and fossil distribution of the species.

Smith, H. M. 1896

A review of the history and results of the attempts to acclimatize fish and other water animals in the Pacific states. U.S. Fish. Comm. Bull. (1895) 15: 379-472.

In May 1893, the New York Fish Commission supplied the California Fish Commission with muskellunge fry from Chautauqua Lake. Ninety-three thousand were stocked in Lake Merced, near San Francisco, to control carp but the attempt was unsuccessful.

Smith, H. M. 1907

The fishes of North Carolina. Vol. 2. North Carolina Geol. Econ. Surv. 453 pp.

For Esox ohiensis gives synonymy, diagnosis, and distribution. Said to be distinct from Esox masquinongy.

Smith, H. M. and M.-M. Snell 1891

Fisheries of the Great Lakes in 1885. pp. 1-333. In U.S. Comm. Fish Fish. Commr. Rep. (1887) Part 15. 900 pp.

Black and white drawing of the muskellunge, here named Esox nobilior, faces page 60 . Said to occur west of Erie. (p. 237)

Smith, K. 1955

A lunge to remember. Outdoor Life 116(5): 66-67, 78-79.

Smith, L. L., Jr. and N. L. Moe 1944

Minnesota fish facts. Minnesota Dep. Conserv. Bull. 7: 1-31.

Smith, O. W. 1922 a

The book of the pike. Cincinnati, Stewart Kidd. 197 pp.

Attempted to be a complete account on the members of the pike family. The literature and history of the family, including some rather unbelievable stories, are given.

The members of the family are tabulated under common name(s), scientific name, and range. Three subspecies of muskellunge are indicated: Esox masquinongy masquinongy, muskellunge, 'lunge; Esox masquinongy ohiensis, Ohio muskellunge, Chautauqua muskellunge; Esox masquinongy immaculatus, great northern pike, plain muskellunge, plain 'lunge. However, the author feels that their differences probably do not merit rank as subspecies.

Notes on how to identify a pickerel, great pike, and muskellunge accompany three figures showing cheek and operculum scalation. Each of the species is described in detail.

Chapters 10 to 12 are devoted entirely to consideration of angling for muskellunge.

Finally, there are notes on how to cook the pike family fishes.

Smith, O. W. 1922 b

The grey wolf of northern waters. Field Stream, August: $435-436$.

Smith, P. W. no date

A key to the fishes of Illinois. Illinois Dep. Conserv. Div. Fish. Fish. Bull. 6. 43 pp.

Esox masquinongy appears in the distributional checklist but it does not appear in the key as it is a species that is said to be long extirpated from the state. 
Smith, P. W. 1971

Illinois streams: a classification based on their fishes and an analysis of factors responsible for disappearance of native species. Illinois Nat. Hist. Surv. Dep. Regist. Educ. Biol. Notes 76.

Smith, S. B. and D. M. Green, Jr. 1974

Fisheries investigations of Canadarago Lake. Food selection by fish. U.S. Fish Wildl. Serv., New York Dep. Environ. Conserv., Cornell Univ., D-J Proj. F-29-R-1, Job 1 e. 9 pp.

The muskellunge is occasionally found in Canadarago Lake.

Snow, H. E. 1960

Murphy flowage. Res. Wisconsin (1959): 14-17.

Snow, H. E. 1962

Warm water fishery research. Murphy Flowage studies. Population estimates. Wisconsin Conserv. Dep., D-J Proj. F-61-R-2, wk. pl. 3, Job C: 10-12.

Snow, H. E. 1966

Statewide fishery research. Murphy Flowage studies. Stunted panfish control. Wisconsin Conserv. Dep., D-J Proj. F-83-R-1, wk. pl. 4, Job B: 8-9, 29-30, 38.

Snow, H. E. 1967 a

Statewide fishery research. Murphy Flowage studies. Northern pike stocking in Murphy Flowage. Wisconsin Conserv. Dep., D-J Proj. F-83-R-2, wk. pl. 3, Job A. 20 pp.

Snow, H. E. 1967 b

Statewide fishery research. Murphy Flowage studies. Muskellunge stocking as a panfish control practice. Wisconsin Conserv. Dep., D-J Proj. F-83-R-2, wk. pl. 3, Job B: 21-31.

Snow, H. E. 1967 c

Statewide fishery research. Northern pike stocking in Murphy Flowage. Wisconsin Conserv. Dep., D-J Proj. F-83-R-3, wk. pl. 3, Job A. 7 pp.

Snow, H. E. 1968 a

Stocking of muskellunge and walleye as a panfish control practice in Clear Lake, Sawyer County. Wisconsin Dep. Nat. Resour. Res. Rep. 38. 18 pp.

Results of stocking muskellunge and walleye fingerlings in a lake containing an extremely abundant and slow-growing bluegill population are reviewed.

Snow, H. E. 1968 b

Statewide fishery research. Stocking of muskellunge and walleye as a panfish control practice in Clear Lake, Sawyer County. Wisconsin Conserv. Dep., D-J Proj. F-83-R-2, wk. pl. 2, SP. $22 \mathrm{pp}$.

Snow, H. E. and T. Beard 1972

Northern pike of Bucks Lake, Wisconsin: including evaluation of an 18.0 inch size limit. Wisconsin Conserv. Dep. Tech. Bull. 56, D-J Proj. F-83-R. 21 pp.

Sonstegard, R. A. MS 1970 a

Descriptive and epizootiological studies of infectious pancreatic necrosis virus of salmonids and lymphosarcoma of Esox masquinongy. Univ. Guelph, Ph.D. thesis, $215 \mathrm{pp}$.

Sonstegard, R. A. 1970 b

Epizootiological evidence for a viral etiology of lymphosarcoma of Esox. Internat. Assoc. Aquatic Anim. Med. Guelph, Canada.

Sonstegard, R. A. 1974

Neoplasia incidence studies in fish inhabiting polluted and non-polluted waters in the Great Lakes of North Amcrica. International Cancer Congress Panel 17: 172-173. 
Sonstegard, R. A. and K. S. Sonstegard 1973

Establishment of a cell line from lymphosarcoma of the muskellunge (Esox masquinongy). In vitro 8(5): 410-411. [Fish Health News 2(3): 15.]

A cell line was established from a biopsy of a lymphosarcoma lesion in muskellunge. Cells were propagated as continuous static suspension cultures for 21 months. They grew as single cells or in macroscopically visible clumps and often exhibited bizarre multinucleated forms. Although no evidence of virus was detected in EM studies, reverse transcriptase assays, or cocultivation trials, other preliminary evidence suggests lymphosarcoma syndrome to be of viral etiology.

Sorenson, L. 1960

Muskies - mite and mighty - at Union City. Pennsylvania Angler 29(2): 9-10.

Sorenson, L. MS 1970

Light and temperature control on muskellunge fry. Pennsylvania, Union City Fish Hatchery. 3 pp. Manuscript.

Sorenson, L. 1971

Injection of carp with dried pituitary to control spawning time. Prog. Fish-Cult. 33(2): 24.

Carp (Cyprinus carpio) offer a partial solution in providing adequate forage for muskellunge culture if their spawning time can be controlled to establish a reliable source of fry. Females were injected with a stock solution of pulverized carp pituitary and chloramphenicol in sterile water. The fish normally spawned within 12 hours and the eggs produced about a 90 per cent successful hatch.

\section{Sorenson, L., K. Buss and A. D. Bradford 1966}

The artificial propagation of esocid fishes in Pennsylvania. Prog. Fish-Cult. 28(3): 133-141.

Results of research study to improve artificial propagation methods in Pennsylvania, which up to then had been largely unsuccessful. Primarily discusses culture methods for pike and muskellunge, from spawning and egg incubation to rearing fry and fingerlings.

\section{Sosin, M. and J. Clark 1973}

Through the fish's eye. An angler's guide to gamefish behaviour. New York, Harper and Row. 249 pp.

\section{Spangler, G. R. MS 1966}

A creel census study of the maskinonge, Esox masquinongy Mitchill. Univ. Toronto, M.Sc. thesis. 24 pp.

During the period 1952 to $1964,3,474$ tagged muskellunge were transplanted from Nogies Creek Sanctuary to the public fishing waters of Pigeon and Sturgeon lakes. A creel census was conducted on Pigeon Lake during the summers of 1961 to 1965 to investigate tag loss, annual catch, and mortality rate.

Pigeon Lake muskellunge exhibit a faster rate of growth than those in Nogies Creek. The length-weight relationship for Pigeon Lake fish agrees very closely with those reported for Nogies Creek, Lake St. Clair, and Chautauqua Lake fish.

\section{Spangler, G. R. 1968}

Angler harvest and mortality of Esox masquinongy in Pigeon and Sturgeon Lakes, Ontario. J. Fish. Res. Board Canada 25(6): 1145-1154.

Results of a creel census conducted on Pigeon Lake, Ontario, to assess the contribution to the fishery of muskellunge transplanted from Nogies Creek Fish Sanctuary. Angler harvest and mortality were estimated, with a correction being made for tag loss.

\section{Speirs, J. M. 1951}

History of the original descriptions of Great Lakes fishes. London, Ontario, Proc. Res. Counc. Ontario Tech. Session, February 24. $38 \mathrm{pp}$.

Discusses the problem of finding Mitchill's original description of the muskellunge and refers to the partial reprint that appeared in DeKay (1842). 
Speirs, J. M. 1952

An outline of fisheries research on the Great Lakes. Summary of Lake Superior fisheries literature. Univ. Toronto, Ontario Fish. Res. Lab. 25 pp. Mimeograph.

Lists literature references for records of each species in Lake Superior, including the muskellunge, which was incorrectly listed as Esox lucius.

Speirs, J. M. 1953

History of the original descriptions on Great Lakes fishes. 38 pp. Mimeograph.

Esox masquinongy is reported to have been originally described from Lake Erie, however the original description (Mitchill, Mirror 1824: 297) has not been found and is known only from DeKay (1842).

Sprecher, G. E. 1945

Wisconsin fishing à la 1944. Wisconsin Conserv. Bull. 10(5-6): 6 .

Srivastava, J. M. 1971

Fish of the Gulf of St. Lawrence, an unabridged bibliography. Fish. Res. Board Canada Tech. Rep. 261. 141 pp.

Stick, F. L. 1917

Getting acquainted with Mose. Field Stream, September: 424-427.

Stockwell, G. A. 1875

Fishes and fishing of the Great Lakes. The whitefish, maskinonge, pike, perch, garpike and sturgeon. For. Stream 5: 293, 327.

Storer, D. H. 1972

A synopsis of the fishes of North America. Amsterdam, A. Asher. [Mem. Am. Acad. Arts Sci. 2: $253-550,1846$.

Taxonomic description and synonymy for Esox estor.

Stroud, R. H. 1957

Sanctuary muskies. Sport Fish. Inst. Bull. 62: 5.

Stroud, R. H. 1958

Two hundred dollar muskies. Sport Fish. Inst. Bull. 84: 1-2.

Sumner, R. E. 1968

Stream and lake survey. Species combinations in small impoundments. West Virginia Div. Game Fish, D-J Proj. F-10-R-10, wk. pl. 3, Job 2, Fin. 15 pp.

Surber, E. W. 1966

Warm water fisheries management investigations. Evaluation of a minimum length limit on largemouth bass. Virginia Comm. Game Inland Fish., D-J Proj. F-5-R-12, Job 12. 58 pp.

Surber, T. 1920

A preliminary catalogue of the fishes and fish-like vertebrates of Minnesota. Minnesota Game Fish Commr. Bien. Rep. (1920) Appendix. 92 pp.

Short account on the muskellunge, primarily reporting observations of various other authors on distribution and speciation.

Surface, H. A. 1900

Food of young muscalonge. For. Stream, April: 21.

Swanson, G. H. 1969

Tiger with fins. Fur-Fish-Game, March: 20-23. 
Sweigart, A. P. 1935

Esox, the voracious life sketch of a chain pickerel. Pennsylvania Angler 4(11): 2-3.

The range of the Chautauqua muskellunge is said to be restricted.

Swint, F. J. 1917

That great musky moment. Field Stream, September.

Taylor, E. G. 1926

Canoe fishing in Wisconsin waters. For. Stream, February: 102, 110-112.

Taylor, J. 1966

World record in muskies. Izaak Walton Outdoor America 31(1): 1-5.

Taylor, Z. 1966

Musky roundup. Sports Afield 156(1): 34, 35, 58.

Development of many new large impoundments in the eastern United States and the high populations of forage fish found in them have made practical the stocking of muskellunge in new areas. It looks as though the muskellunge might help solve the problem of too many stunted forage fish in reservoirs while adding a new sport fish. Muskellunge are not detrimentally competitive with the basses. (Author's abstract)

Taylor, Z. 1969

Houseboating in musky country. Sports Afield, January: 48-51, 63.

Taylor, Z. 1970

What's the truth about all those muskie lies? Rod Gun, Summer: $64-68,178,185$.

Tennant, D. 1954

"Our rocky fort muskies". Ohio Conserv. Bull. 18(11): 8-9.

Tennant, D. and G. Billy 1963

Artificial hybridization of the muskellunge and grass pickerel in Ohio. Prog. Fish-Cult. 25(2): $68-70$.

A male muskellunge (Esox masquinongy) was successfuly crossed with a female grass pickerel (Esox americanus vermiculatus).

Tennant, D., J. Mann and R. Reithmiller 1953

We're trying to make muskies. Ohio Conserv. Bull. 17(7).

Thomas, B. 1971

Reb muskies. Fish. World, March/April: 38-41, 54-56.

Thompson, C. S. 1900

The water wolf. Outing Mag., June: 264-265.

Thompson, Z. 1851

No title. (Note read to a meeting). Proc. Boston Soc. Nat. Hist. (1848-1851) 3: 164, 305-306.

Discussion of relationship of Esox lucius, E. estor, and E. nobilior.

Threinen, C. W. 1949

Result of a pilot marking experiment on muskellunge fingerlings. Wisconsin Conserv. Dep. Div. Fish Manage. Invest. Rep. 712. 3 pp.

Threinen, C. W. 1957 a

Accepted common names of Wisconsin fish. Wisconsin Conserv. Bull. 22(6): 22-23.

Common and scientific names of the muskellunge are listed. 
Threinen, C. W. 1957 b

What's new in fish management. Wisconsin Conserv. Bull. 22(10): 25

Briefly discusses growth differential for same-age fish.

Threinen, C. W. 1958 a

What's new in fish management. Wisconsin Conserv. Bull. 23(7): 8.

Creel census taken in 1957 indicated there was one muskellunge for every 5.6 acres of water in Wisconsin.

Threinen, C. W. 1958 b

What's new in fish management. Wisconsin Conserv. Bull. 23(8): 17.

Describes the unsuccessful attempt to rear muskellunge at the state fish hatchery.

Threinen, C. W. $1958 \mathrm{c}$

What's new in fish management. Wisconsin Conserv. Bull. 23(11): 12.

Short note mentions innovation of tank rearing of muskellunge.

Threinen, C. W. $1958 \mathrm{~d}$

What's new in fish management. Wisconsin Conserv. Bul1. 23(12): 18-19.

Very brief note on Five Lake statistics.

Threinen, C. W. 1959

What's new in fish management. Wisconsin Conserv. Bull. 25(9): 24-25.

Paragraph note on bearing of predation in deciding upon hatchery procedure.

Threinen, C. W. and A. Oehmcke 1952

The northern invades the musky's domain. Wisconsin Conserv. Bull. 15(9): 10-12.

Threinen, C. W. and D. W. Walker 1958

A survey of muskellunge fishermen. Wisconsin Conserv. Dep. Misc. Rep. 1. 10 pp.

Threinen, C. W., C. Wistrom, B. Apelgren and H. Snow 1966

The northern pike. Life history, ecology, and management. Wisconsin Conserv. Dep. Publ. 235. $16 \mathrm{pp}$.

Toner, G. C. no date

Conservation and Canada's game fish. Carling Conserv. Club. 8 pp.

Paragraph note outlines information on size, resemblance to northern pike, and spawning habits for the muskellunge.

Toner, G. C. 1933

Annotated list of fishes of Georgian Bay. Copeia 1933(3): 133-140.

Although it was once quite common to Georgian Bay, the numbers of the muskeliunge were said to have dwindled.

Toner, G. C. 1937

Preliminary studies of the fishes of eastern Ontario. Eastern Ontario Fish Game Protective Assoc. Bull. Suppl. 2. 24 pp.

Refers to literature records of muskellunge found in Leeds and Frontenac Counties of Ontario as well as to very large mounted specimens seen by the author.

Touart, P. 1973

Guide lines. Sports Recreation, July/August: 10.

Trandahl, A. J. 1974

Formulated dry diet feeding - 1974. Morehead, Kentucky, Proc. 6th Interstate Muskellunge Workshop, September 25-26: 28-30. Mimeograph.

Summarizes dry diet programmes at five fish hatcheries in the United States. 
Trautman, M. B. 1948

When do pike shed their teeth? Michigan Conserv. Bull. 17(8): 4-5, 10.

Trautman, M. B. 1957

The fishes of Ohio with illustrated keys. Ohio Univ. Press. 683 pp.

The Great Lakes muskellunge and the Ohio muskellunge are treated separately. For both there is an account given under the headings: identification, distribution, and habitat. (pp. 35, 215. 218)

Trautman, M. B., and C. L. Hubbs 1935

When do pike shed their teeth? Trans. Am. Fish. Soc. 65: 261-266.

Travis, T. 1922

The hoodod of French River. For. Stream, March: 112-113, 142-144.

Trembley, G. 1964

Pennsylvania's muskellunge program. Pennsylvania Angler 33.

Tripp, S. 1965

The Pigeon River musky nursery. Outdoorsman: 58-62.

Historical review of attempts made to improve muskellunge fishing in the Kawartha area, Ontario, from 1927-1965. A hatchery was established to rear muskellunge artificially and the Nogies Creek Research Station was established in 1951. The article is accompanied by a number of black and white photographs.

Trombley, R. L. 1974

Muskellunge forage. Morehead, Kentucky, Proc. 6th Interstate Muskellunge Workshop, September 25-26: 34-35. Mimeograph.

Point form note briefly outlines method and success of obtaining fish and plankton forage for muskellunge.

Ulmann, A. 1921

The king of the tribe of Esox. For. Stream, October: 444-445, 466-468.

Uthe, J. R., E. Roberts, L. W. Clarke and H. Tsuyuki 1966

Comparative electropherograms of representatives of the families Petromyzontidae, Esocidae, Centrarchidae, and Percidae. J. Fish. Res. Board Canada 23(11): 1663-1671.

The starch gel electropherogram of muscle myogens and blood hemoglobins of representatives of various families, including Esocidae, were found to be within the limits of species' specificity, with some exceptions. These natural chemical markers are discussed from the standpoint of their usefulness in subpopulation analysis.

Van Meter, H. 1950

ldentifying fifty prominent fishes of West Virginia. West Virginia Conserv. Comm. Div. Fish Manage. Publ. 3. 45 pp.

Short note for anglers outlines distribution, size, preferred tackle, and external features of muskellunge. Small drawing indicates distinguishing features.

Van Meter, H. D. and M. B. Trautman 1970

An annotated list of the fishes of Lake Erie and its tributary waters exclusive of the Detroit River. Ohio J. Sci. 70(2): 65-78.

Van Oosten, J. 1946

The pikes. U.S. Fish Wildl. Serv. Fish. Leafl. 166. 6 pp.

Revised by Van Oosten (1960). 
Van Oosten, J. 1957

Exotics and hybrids in fish management. Proc. Assoc. Midwest Game Fish Comm. 24th Annu. Meet.: 17-22.

Van Oosten, J. 1960

The true pikes. U.S. Fish Wildl. Serv. Fish. Leafl. 496.9 pp.

General note.

Vasey, F. W. 1968

Fisheries management planning and research. The fishery of Pomme de Terre Reservoir. The fish population of Pomme de Terre Reservoir. Missouri Conserv. Comm., D-J Proj. F-1-R-17, wk. pl. 18 , Job 1.9 pp.

Vasey, F. W. 1972

Fisheries management planning and research. Fish populations of Pomme de Terre Reservoir. Missouri Conserv. Comm., D-J Proj. F-1-R-16, wk. pl. 18, Job 1. 30 pp.

Vesey-Fitzgerald, B. and F. Lamonte, eds. no date

Game fish of the world. New York, Harper and Brothers. 446 pp.

The muskellunge is discussed in two chapters of this book, one on the pikes and walleye and the other on game fishing in Canada. In the former, voracity, distribution, habits, and habitat of the muskellunge are described, and the latter indicates where to find the muskellunge.

Vigren, D. 1965

Musky jamboree. Fish. World, September/October: 43-45.

Vincent, B. et V. Legendre 1974

Répartition géographique du maskinongé, Esox masquinongy, dans le district des Laurentides. Compilation 1972. Québec Minist. Tourisme Chasse Pêche Serv. Aménagement Faune Serv. Recherche Biol. 5 pp.

Distribution of planted muskellunge in the Laurentides District, Quebec.

Voight, W. C. 1928

Bait casting. New York, Longmans, Green.

Wagner, C. C. and E. L. Cooper 1963

Population density, growth, and fecundity of the creek chubsucker, Erimyzon oblongatus. Copeia 1963(2): 350-357.

The young of the creek chubsucker are thought to be valuable as forage for piscivorous game fishes such as the muskellunge.

Wahl, R. M. 1958

First muskie stocking. West Virginia Conserv. Comm., November: 18-19.

Walden, H. T., II 1964

Familiar freshwater fishes of America. 1st ed. New York, Harper and Row. 324 pp.

Walker, V. J. and D. R. Johnston 1962

Ontario Maskinonge project, Lake St. Clair, Summer — Fall, 1961. Ontario Dep. Lands For. Rep. 4 pp. Mimeograph.

To determine information on movement, distribution, abundance, and life history, muskellunge were tagged and released in Lake St. Clair. Water temperature, oxygen concentration, and secchi disc readings were taken at 12 stations and a creel census was conducted.

A further tagging operation was conducted in autumn in cooperation with two commercial fishermen. Length and weight data from Tommy's Boat Livery, Detroit, are included. 
Walker, K., S. Kmiotek and A. Oehnicke 1958

Muskellunge trough-rearing experiment. Wisconsin Conserv. Dep. Fish Manage. Div. Northwest Area Invest. Memo. 2. 8 pp.

This report provides information on the equipment used, procedures followed, and results obtained during an experiment to determine the value of trough-rearing muskellunge fry.

Walkinshaw, C. A. 1947

Maskinonge population. Ontario Fed. Anglers Hunters, News Lett. Bull. 9(2): 1-3.

Waters, J. 1953

There's a tiger in our waters. Ohio Conserv. Bull, 17(10): 20-21, 28-29.

Webster, B. O. 1929

Propagation of muskellunge. Trans. Am. Fish. Soc. (1929) 59: 202-203.

Describes artificial culture of the muskellunge in Wisconsin and initial attempts to rear muskellunge to fingerling size before planting.

Webster, B. O. 1934

Report of the Vice-president of the Division of Fish Culture. Trans. Am. Fish. Soc. 64: 28-32.

Weed, A. C. 1925

Feeding the muskalonge. Copeia 146: 69-70.

The feeding habits of a muskellunge, (Esor immaculatus Garrard), in captivity, were studied. A detailed description is given of a muskellunge taking a carp.

Weed, A. C. 1927

Pike, pickerel and muskalonge. Chicago Field Mus. Nat. Hist. Zool. Leafl. 9: 158-204. (52 pp.)

Attempts to solve the difficulty in naming and identifying fish in the pike family by giving descriptions and pictures of all the fishes involved. Discusses the power that pickerel and pike have of changing colour and colour pattern to suit their surroundings and the colour and markings that one could expect on the various pike species.

Scalation on cheek and operculum to distinguish the pikes is given. There is a key to species of Esox including three so-called species of muskellunge, $E$. masquinongy, $E$. ohioensis, $E$. immaculatus. There are notes on description and distribution for each of these species.

A useful list of scientific names with cross references and common names with cross references concludes the paper.

Weir, J. C. 1955

Nogies Creek Fish Sanctuary. Ontario Dep. Lands For. Lindsay Dist. Newsl. 4 pp. Mimeograph.

Weithman, S. MS 1975

Survival, growth, efficiency, preference and vulnerability to angling of Esocidae. Univ. Missouri, M.Sc. thesis. $97 \mathrm{pp}$.

Wellman, P. I. 1957

How to catch a muskie. Field Stream, May: 88-89, 121-131.

Welter, W. A. 1938

A list of fishes of the Licking River drainage in eastern Kentucky. Copeia 1938(2): 64-68. Esox masquinongy ohiensis Kirtland was collected from the Licking River drainage.

West, J. L. MS 1968

The growth and reproduction of three intergeneric centrarchid hybrids. North Carolina State Univ., Ph.D. thesis. 143 pp. 
Whitaker, J. O., Jr. 1968

Keys to the vertebrates of the eastern United States excluding birds. Minneapolis, Burgess. 255 pp.

In key and distribution map. (pp. 20-21)

White, M. O. and R. E. Gehres 1962

Muskellunge stocking evaluation and age-growth in Piedmont Lake. Ohio Div. Wildl. 6 pp. Mimeograph.

Whitehouse, F. C. 1948

Spor fishing in Canada. Vancouver, Published by author. $188 \mathrm{pp}$.

Primarily of interest to anglers. Contains a section on the muskellunge in which the following subjects are discussed: distribution, distinguishing muskellunge from pike, spawning, voracity, maximum size, fishing qualities, and methods of fishing. The muskellunge is compared to the barracuda. Includes a black and white photograph of a Royal Ontario Museum specimen.

Whitley, J. R. 1967

Fisheries management planning and research. Control of undesirable aquatic vegetation. Missouri Conserv. Comm., D-J Proj. F-1-R-16, wk. pl. 4, Job 3. 10 pp.

Wich, K. and J. W. Mullan 1958

A compendium of the life history and ecology of the chain pickerel Esox niger (Le Sueur). Massachusetts Div. Fish Game Fish Bull. 22. 23 pp.

Mentions artificial hybridization between Esox niger and Esox masquinongy.

Wickliff, E. L. no date

A review of the status of the mascalonge with special reference to the Ohio or Chautauqua Mascalonge. 5 pp. Mimeograph.

Three forms of muskellunge, the Ohio, the Lake Erie, and the Wisconsin, are described and considered to be distinct. Statements of authors such as Rafinesque, Jordan and Evermann, and Henshall are referred to. With emphasis on the Ohio form, the following aspects of the muskellunge are discussed: spawning habits, voracity, protection during spawning period.

Wickliff, E. L. 1933

A review of the status of the muskellunge with special reference to the Ohio or Chautauqua mascalonge. Ohio Div. Conserv. Dep. Agric. Bur. Sci. Res. Bull. 27. 4 pp.

Williams, J. E. 1948

The muskellunge in Michigan. Michigan Dep. Conserv. Bull. 17(10): 10-11, 15 .

Of interest primarily to the sport fisherman, this paper deals with: best Michigan locations for catching muskellunge, record catches, how to catch, length-weight and age-size relationships and explanations, and details of record muskellunge netted.

\section{Williams, J. E. 1953}

The techniques of rearing fingerling walleye and muskellunge as practiced by Wisconsin and Minnesota, and the status of the program as a management tool. Michigan Conserv. Dep. Div. Fish. 1nst. Fish. Res. Rep. 1365. 57 pp.

Williams, J. E. 1954 a

Spawn collection and spawning habits of northern muskellunge in Gogebic County in 1954. Michigan Conserv. Dep. 1nst. Fish. Res. Rep. 1430. 33 pp.

Describes cooperative muskellunge spawn collection by Wisconsin and Michigan in 1954 . Although approximately 400,000 muskellunge eggs were collected and fertilized, only 10 fry hatched. Poor survival was attributed to chilling eggs before and after shipment. Considered muskellunge in lakes near the Wisconsin-Michigan border to be distinct subspecies (Esox masquinongy immaculatus). 
Williams, J. E. 1954 b

Creel census and life history observations concerning muskellunge in Michigan inland waters. Michigan Conserv. Dep. Inst. Fish. Res. Rep. 1432. 67 pp.

Discusses observations made on the muskellunge in its natural habitat, incidental to spawn collection. Information on muskellunge obtained by creel census was used to locate fish, determine time of spawning, and make management recommendations. Winter and summer creel census returns are discussed in detail and analysed. Attempts to propagate muskellunge arificially were unsuccessful.

Williams, J. E. 1959 a

The muskellunge in Michigan. Michigan Dep. Conserv. Fish Div. Pam. 30, D-J Proj. F-15R-2. 5 pp.

Williams, J. E. 1959 b

Techniques for management of warm-water fish. Evaluation of introductory and maintenance stocking of muskellunge. Michigan Dep. Conserv., D-J Proj. F-15-R-1, Job 12: 6-8.

Williams, J. E. 1959 c

Techniques for management of warm-water fish. Fish growth-rate studies. Michigan Dep. Conserv., D-J Proj. F-15-R-1, Job 13: 8-9.

Williams, J. E. 1960

Techniques for management of warm-water fish. Preparation of a monograph on northern pike and muskellunge. Michigan Dep. Conserv., D-J Proj. F-15-R-2, Job 14: 11-16.

Williams, J. E. 1961 a

The muskellunge in Lake St. Clair. Michigan Dep. Conserv. Div. Fish. Inst. Fish. Res. Rep. 1625. 30 pp. Mimeograph.

The following information was obtained from a study of the Lake St. Clair muskellunge: length, weight, length-weight relationship, spawning, and numbers caught. Contains a comparison of Ontario and Michigan regulations.

Williams, J. E. 1961 b

Techniques for management of warm-water fish. Sampling of lake fish populations with seines and toxicants. Michigan Dep. Conserv., D-J Proj. F-15-R-3, Job 2. 5 pp.

Williams, J. E. 1961 c

Techniques for management of warm-water fish. Observations on spawning habits of predatory fish. Michigan Dep. Conserv., D-J Proj. F-15-R-3, Job 10: 14, $18-48$.

Williams, J. E. 1962

Techniques for management of warm-water fish. Sampling of lake fish populations with seines and toxicants. Michigan Dep. Conserv., D-J Proj. F-15-R-4, Job 2. 6 pp.

Williams, J. E. 1963

Research and management of sport fisheries of Michigan. Development and evaluation of techniques for management of warm-water fishes, evaluation of introductory and maintenance stocking of muskellunge. Michigan Dep. Conserv., D-J Proj. F-27-R-1, wk. pl. 3, Job 11: 7.

Williams, J. E. 1965 a

Research and management of sport fisheries of Michigan. Development and evaluation of techniques for management of warm-water fishes. Evaluation of the effects of the reduction in abundance of bluegills in lakes. Michigan Dep. Conserv., D-J Proj. F-27-R-2, wk. pl. 3, Job 3. $6 \mathrm{pp}$.

\section{Williams, J. E. 1965 b}

Research and management of sport fisheries of Michigan. Development and evaluation of techniques for management of warm-water fishes. Evaluation of introductory and maintenance 
stocking of muskellunge. Michigan Dep. Conserv., D-J Proj. F-27-R-2, wk. pl. 2, Job 9: $8-10$.

Williams, J. E. 1965 c

Research and management of sport fisheries of Michigan. Development and evaluation of techniques for management of warm-water fishes. Evaluation of muskellunge regulations of Lake St. Clair. Michigan Dep. Conserv., D-J Proj. F-27-R-2, wk. pl. 3, Job 11: 10-12.

Williams, J, E. 1966

Research and management of sport fisheries of Michigan. Development and evaluation of techniques for management of warm-water fishes. Evaluation of introductory and maintenance stocking of muskellunge. Michigan Dep. Conserv., D-J Proj. F-27-R-3, wk. pl. 3, Job 9. 2 pp.

Williams, J. E. 1967

Research and management of sport fisheries of Michigan. Development and evaluation of techniques for management of warm-water fishes. Evaluation of introductory and maintenance stocking of muskellunge. Michigan Dep. Conserv., D-J Proj. F-27-R-4, wk. pl. 3, Job 9. 3 pp.

Williams, J. E. 1968

Warmwater fish biology and population ecology. Evaluation of maintenance stocking of muskellunge. Michigan Dep. Conserv., D-J Proj. F-29-R-1, Job 4. 6 pp.

Williamson, L. O. 1940 a

Muskellunge tagging. Progress report 1. Wisconsin Conserv. Bull. 5(6): 51-53.

Discusses results of a two-year tagging and recapture study of muskellunge in a Wisconsin lake.

Williamson, L. O. $1940 \mathrm{~b}$

Length-weight relationship of fish. Wisconsin Conserv. Bull. 5(9): 37-40.

Length-weight relationships of muskellunge given in tabular form.

Williamson, L. O. 1942

Spawning habits of muskellunge, northern pike. Wisconsin Conserv. Dep. Bull. 7(5): 10-11.

Wilson, R. L. 1967

The Pleistocene vertebrates of Michigan. Michigan Acad. Sci. Arts Lett. Pap. 52(1): 197-234.

Dentaries and skull parts were identified as muskellunge bones. They were found in postglacial deposits at the Fenton Lake locality, Michigan.

Witman, B. 1970

Big plugs for big Penn. musky — now! Fish. Hunting Guide, December: 43-71.

Wolf, B. 1956

Recipes for Esox. Sports Afield, July: 40-42, 76-77.

Wooding, F. H. 1959

The angler's book of Canadian fishes. Don Mills, Ontario, Collins. 303 pp.

Short account on description, distribution, characteristics (including spawning and growth), and angling methods. Several other vernacular names are listed. (pp. 185-188)

Wooding, F. H. 1972

The book of Canadian fishes. Toronto, McGraw-Hill Ryerson. 303 pp.

Information on the muskellunge given under the following headings: description, distribution, characteristics, and how caught. (pp. 185-188) Actually a revised edition of Wooding (1959).

Woods, L. P. 1956

Musky - pike and pickerel. Sports Afield, July: 20-25, 82. 
Wright, A. H. and A. A. Allen 1913

The fauna of Ithaca. N.Y. Fishes. In Field note-book of fishes, amphibians, reptiles and mammals. Ithaca, New York.

Brief note.

Wright, R. 1892

Preliminary report on the fish and fisheries of Ontario. Ontario Fish Game Comm. 476 pp.

There is a shor description of the muskellunge, referred to as the maskinonge, Esox nobilior. Characters that distinguish it from pike are given.

Wurdels, M. B. 1974

Muskie Bustin' with bucktails. Fins Feathers 3(7).

Wurzer, A. W. 1953

He makes his muskie luck. Outdoor Life 112(2): 39, 69.

Wydallis, E. A. 1960

Observations on the scale development patterns of the eastern chain pickerel, northern pike, Great Lakes muskellunge. Ohio muskellunge, and yellow walleye with respect to age and length. Ohio Univ. Nat. Resour. Inst. Fish. Res. Rep. (1959-1960). 142 pp. Mimeograph.

Hatchery reared specimens were used in this study to determine origin and development of scales. Skin, removed from preserved specimens, bleached and stained, was examined under a microscope. In Esox species, scalation begins above and below the lateral line and in the area below the posterior half of the dorsal fin. Two groups of muskellunge - considered subspecies - were examined.

Young, J. K. 1970

The fish populations of Lake Nipissing - their growth, distribution and habits. Ontario Dep. Lands For. Manage. Unit Preliminary Rep. 56 pp. Mimeograph.

Outlines areas in Lake Nipissing that muskellunge frequent but explains that there is a low population. Includes a growth-rate table from Harkness (1936).

Young, J. K. MS 1971

Maskinonge fishing in Lake Nipissing. Ontario Dep. Lands For. Nipissing-Temagami Fish. Manage. Unit. $21 \mathrm{pp}$. Manuscript.

Results of a creel census of Lake Nipissing fishermen. Scale samples returned with the questionnaires were used to establish age-length and length-weight relationships.

Zim, H. S. and H. H. Shoemaker 1956

Fishes. A guide of fresh- and salt-water species. Golden Nature Guide, New York, Simon and Schuster. 160 pp.

Paragraph note and colour illustration.

Zimmerman, F. A. 1963

A note on the maskinonge fishing in Bass Lake, Manitoulin Island, 1962. Ontario Dep. Lands For. Sudbury Dist. 2 pp. Mimeograph.

Brief summary of the production of muskellunge in Bass Lake, Ontario, based on the creel of an angler.

Zimmerman, F. A. 1964

Maskinonge fishing in Bass Lake, Manitoulin Island, 1963. Ontario Dep. Lands For. 3 pp. Mimeograph.

Summarizes creel census data collected from 65 anglers fishing in Bass Lake. They caught a total of 80 muskellunge, 34 of which were of legal size. Weight and length averages and ranges are reported for the muskellunge caught.

Zwirz, B. 1967

Tigers of the lakes. Sportfishing, August: 11-13, 54. 
Zwirz, B. 1969

Fall tiger hunt. Sportfishing, September/October: 17-18, 38-39.

Zwirz, B. 1975

Proven methods for walleye, pike and muskie. Fish. Guide: 56-61, 121. 


\section{Accounts by Geographical and Political Areas}

Anon. 1928

Anon. 1975

Ackerman, B. 1955

Bailey, R. M. 1951

Bailey, R. M. 1956

Bean, T. H. 1902

Bean, T. H. 1903

Bensley, B. A. 1915

Black, R. D. 1934

Clay. W. M. 1962

Clay, W. M. 1975

Clinton, D. 1815

Cuerrier, J.-P. 1948

Dickinson, W. E. 1960

Evermann, B. W. and E. L.

Goldsborough 1901

Evermann, B. W. and E. L.

Goldsborough 1902

Fedoruk, A. N. 1969

Fedoruk, A. N. 1971

Forbes, S. A. and R. E. Richardson 1920

Greeley, J. R. 1929

Greeley, J. R. 1938

Greeley, J. R. and S. C. Bishop 1932

Greeley, J. R. and C. W. Greene 1931

Harlan, J. R. and E. B. Speaker 1956

Herald, E. S. no date

Hinks, D. 1943

Hubbs, C. L. 1926

Hubbs, C. L. and K. F. Lagler 1941

Hubbs, C. L. and K. F. Lagler 1964

Jordan, D. S. 1882

Kirtland, J. P. 1838 b

Kuhne, E. R. 1939

La Monte, F. 1945

Legendre, V. 1952 c

McAllister, D. E. and B. W. Coad 1974

McAllister, D. E. and E. J.

Crossman 1973 a

McAllister, D. E. and E. J.

Crossman 1973 b

McCrimmon, H. R. 1956

MacCrimmon, H. R. and E. Skobe 1970

MacKay, H. H. 1963
Macins, V. 1972

Mélançon, C. 1958

Montpetit, A.-N. 1897

Moore, G. A. 1968

Morris, A. G. 1967

Morris, J., L. Morris and L. Witt 1972

Nash, C. W. 1908

Osbum, R. C. 1901

Oughton, J. P. MS 1930 a

Oughton, J. P. MS 1930 b

Paetz, M. J. and J. S. Nelson 1970

Pflieger, W. L. 1975

Scott, W. B. 1967

Scott, W. B. and E. J. Crossman 1975

Slastenenko, E. P. 1958

Small, H. B. 1865

Smith, H. M. 1907

Surber, T. 1920

Trautman, M. B. 1957

Van Meter, H. 1950

Wright, A. H. and A. A. Allen 1913

\section{Age and Growth}

Armstrong, A. E. MS 1963

Brewer, D. L. 1968 b

Brewer, D. L. 1968 c

Brewer, D. L. $1970 \mathrm{c}$

Buss, K. and J. Miller 1961 a

Buss, K. and J. Miller 1961 b

Casselman, J. M. 1975

Couture, R. 1964

Crossman, E. J. MS 1954 a

Crossman, E. J. 1956

Devitt, O. E. 1953

Devitt, O. E. 1958

Dube, J. A. and C. A. Rettie 1961

Eddy, S. and K. D. Carlander 1939

Eddy, S. and K. D. Carlander 1942

Fry, F., J.-P. Cuerrier et G.

Préfontaine 1941

Greeley, J. R. 1938

Harkness, W. J. K. 1945

Hourston, A. S. 1952 
Johnson, L. D. 1958 b

Johnson, L. D. 1960 a

Johnson, L. D. 1965 c

Johnson, L. D. 1967 a

Johnson, L. D. $1967 \mathrm{f}$

Johnson, L. D. 1969 b

Johnson, L. D. 1971 a

Juday, C. and C. L. Schloemer 1938

Laarman, P. W. 1963

Laarman, P. W. 1964

Mellen, I. M. 1919

Miller, J. and K. Buss no date

Muir, B. S. 1960

Nikol'skii, G. V. 1961

Parsons, J. W. 1959

Robinson, D. W. 1959

Schloemer, C. L. 1936

Schloemer, C. L. 1938

Simard, A. MS 1966

Simard, A. and E. Magnin 1968

Threinen, C. W. 1957 b

Weithman, S. 1975

White, M. O. and R. E. Gehres 1962

Williams, J. E. 1959 c

Wydallis, E. A. 1960

Young, J. K. 1970

\section{Anatomy}

Bachop, W. E. MS 1958

Bachop, W. E. MS 1963

Bachop, W. E. 1964

Bachop, W. E. 1965

Bachop, W. E. 1966

Bachop, W. E. 1967

Bachop, W. E. 1968

Bachop, W. E. and E. J. Harris 1971

Bachop, W. E. and J. W. Price 1969

Bachop, W. E. and J. W. Price 1971

Bachop, W. E. and F. J. Schwartz 1974

Beamish, R. J., M. J. Merrilees and E. J. Crossman 1971

Berg, L. S. 1936

Boldyreff, E. B. 1935

Crossman, E. J. 1960

Davisson, M. T. 1972

Derochers, J. 1895

Fish, M. P. 1932

Galat, D. L. 1972
Galat, D. L. 1973

Gregory, W. K. 1933

Johnson, L. D. 1954 c

McGregor, J. F. 1970

Merrilees, M. J. MS 1972

Merrilees, M. J. and E. J. Crossman 1974

Nelson, G. J. 1969

Roussow, G. 1961

Trautman, M. B. 1948

Trautman, M. B. and C. L. Hubbs 1935

Wydallis, E. A. 1960

\section{Angling and Record Catches}

Anon. (O. O. S.) 1888

Anon. $1940 \mathrm{~b}$

Anon. 1957

Anon. $1970 \mathrm{c}$

Aflalo, F. G. 1911

Anderson, L. A. 1963

Anderson, L. A. 1973

Armstrong, G. C. 1967

Balcerzak, R. 1971

Bauer, P. 1964

Bean, T. H. 1908

Bergh, K. 1969

Best, E. 1971

Brabant, J. 1977

Brooks, J. 1972

Bryant, G. W. 1954

Buss, K. 1961 a

Caine, L. S. 1949

Camp, R. R. 1951

Carroll, D. 1917

Cartier, J. O. 1967

Chamberland, R. B. 1946

Chambers, E. T. D. 1904 a

Chapralis, J. C. 1954

Chapralis, J. C. 1964

Chapralis, J. C. 1969

Churchill, W. S. 1968

Churchill, W. S. and W. Snow 1964

Claflin, B. 1945

Clark, G. 1947

Clark, G and C. H. May, eds. no date

Clay, S. 1971

Connor, J. 1955

Connor, J. 1956 
Couch, C. 1947

Cross, H. 1943

Czura, P. 1971

Dalrymple, B. W. 1961

Dalrymple, B. 1962

Dalrymple, B. 1968

Davis, W. 1958

Davis, W. 1961

Davis, W. 1964

Decker, E. N. 1922

DeGroot, W. G. 1901

Dieckman, M. 1965

Duck, H. 1971

Elliot, C. 1957

Ellis, M. 1953

Ellis, M. 1957

Ellsworth, F. B. 1915

Evanoff, V., ed. 1962

Fine, I. and E. Werner 1960

Ford, C. 1959

Fuelsch, D. 1963

Fuller, B. 1969 a

Fuller, B. 1969 b

Fuller, B. 1974

Gleason, J. B. 1962

Gleason, J. B. 1966

Gordon, S. W. 1955

Goth, L. A. 1974

Graham, F. H. 1919

Halstadt, W. 1957

Hamer, C. 1973

Hamer, C. 1974

Hanson, A. 1949

Harbour, D. 1972

Harding, J. C. 1915

Hartman, L. 1962

Hartman, L. 1967

Haver, P. 1962

Haworth, P. L. 1910

Hayden, C. A. 1904

Hayes, J. 1965

Hayes, J. 1967

Heacox, C. E. 1958

Henry, S. 1970 a

Henry, S. 1970 b

Henshall, J. A. 1892

Herity, J. C. 1974

Herity, J. C. 1975
Holden, G. P. 1927

Hough, E. 1890

Hough, E. 1901

Howard, S. H., ed. 1942

Ivis, F. M. 1902

Jackson, J. W. 1958

Jay, D. 1968

Jay, D. 1971

Johnson, C. 1929 a

Johnson, C. 1942

Johnson, L. D. 1954 c

Johnson, L. D. 1956 b

Johnson, P. 1949

Johnson, R. E. 1945

Jurgens, J. 1971

Jurgens, J. 1972

Keats, J. 1958

Keats, J. 1962

King, F. 1963

Kirby, E. 1957

Klingbiel, J. 1962

Knourek, F. J. 1972

Knourek, F. J. 1973

Krommer, R. S. 1971

Krotzer, K. 1959

Lane, T. 1966

Lawton, A. 1958

LeBlanc, H. 1969

LeBlanc, H. 1974

Lee, G. R. 1957

Lewis, B. 1968

Lienhard, J. 1961

Lincoln, R. P. 1921

Lincoln, R. P. 1922

Lincoln, R. P. 1948

Lindner, B . 1976

Lockhart, J. 1957

Lucas, J. 1952

Lucas, J. 1953 b

Lucas, J. 1960

Lynde, H. 1891

McClane, A. J. 1953

McClane, A. J. 1954

MacDonald, B. 1950

McKeaque, H. T. and I. C. Rheaume 1956

McNally, T. 1971

MacQuarrie, G. 1956 a 
MacQuarrie, G. 1956 b

MacQuarrie, G. and P. Drotning 1947

Malz, C. 1974

Martin, J. 1974

Martin, R. 1970 a

Martin, R. 1970 b

Martin, R. 1970 c

Martin, R. 1970 d

Mather, F. 1898

Mattis, G. C. 1956

Mattis, G. C. 1964

Mattis, G. C. 1966

Mattis, G. C. 1970

Meseroll, S. 1974

Michaels, C. 1970

Miller, F. E. 1963

Morikubo, S. 1929

Morikubo, S. 1930

Moselle, A. 1953

Moses, B. 1926

Mosher, A. A. 1892

Myers, I. K. 1915

Nansen, C. 1973

Parks, G. H. 1920

Peterson, K. D. 1890

Poole, E. G. 1937

Porter, E. C. 1925

Quarles, J. V., Jr. no date

Ramsell, L. A. 1976 a

Ramsell, L. A. 1976 b

Rathom, J. R. 1902

Reddick, D. V. 1944

Rhead, L. 1910

Rhead, L. 1917

Richards, G. 1968

Richey, D. 1970

Richey, D. 1975

Robinson, B. C. 1920 a

Robinson, B. C. 1920 b

Robinson, B. C. 1923

Robinson, B. C. 1925

Robinson, B. C. 1928

Robinson, B. C. 1945

Robinson, B. C. 1948

Robinson, B. C. 1959

Robinson, B. C. 1963 b

St. John, L. 1920

Sandys, E. W. 1895
Schaldach, W. J. 1943

Schara, R. 1969

Scharf, J. A. 1966 a

Scharf, J. A. 1966 b

Scotford, F. E. 1908

Scott, J. D. 1972

Seaman, R. 1956

Shaw, D. 1958

Shea, P. 1971

Shoemaker, M. E. 1942

Slone, T. H. 1918

Small, H. B. 1865

Smith, K. 1955

Smith, O. W. 1922 a

Smith, O. W. 1922 b

Sosin, M. and J. Clark 1973

Swint, F. J. 1917

Taylor, E. G. 1926

Taylor, J. 1966

Taylor, Z. 1969

Taylor, Z. 1970

Thomas, B. 1971

Thompson, C. S. 1900

Touart, P. 1973

Travis, T. 1922

Voight, W. C. 1928

Wellman, P. 1. 1957

Witman, B. 1970

Wurdels, M. B. 1974

Wurzer, A. W. 1953

Zwirz, B. 1969

Zwirz, B. 1975

\section{Behaviour}

Colesante, R. T. 1977

Graff, D. R. MS 1972

Johnson, L. D. 1962 a

Johnson, L. D. 1965 a

Muir, B. S. MS 1957

\section{Commercial Fishing}

Anon. 1896 b

Dymond, J. R. 1939

Dymond, J. R. 1964 b 


\section{Creel Census}

Anon. $1970 \mathrm{c}$

Bemard, C. 1967

Churchill, W. S. 1962 a

Courtemanche, A. MS 1963 b

Courtemanche, A. MS 1964

Dube, J. A. and C. A. Rettie 1961

Dursley, R. S. and F. E. J. Fry 1961

Erickson, J. 1961

Fry, F., G. Préfontaine et J.-P. Cuerrier 1941

Hacker, V. A. 1966

Hacker, V. A. 1973

Hasse, J. J. MS 1976 a

Heacox, C. E. 1946

Kempinger, J. J. 1972

Moore, E. 1938

Moore, E. and staff 1938

Netsch, M. F. and W. L. Turner 1954

Pasko, D. G. 1949

Spangler, G. R. MS 1966

Spangler, G. R. 1968

Threinen, C. W. 1958 a

Threinen, C. W. and D. W. Walker 1958

Walker, V. J. and D. R. Johnston 1962

Williams, J. E. 1954 b

Young, J. K. MS 1971

Zimmerman, F. A. 1963

Zimmerman, F. A. 1964

\section{Culture and Artificial Propagation}

Anon. 1896 a

Anon. 1907 a

Anon. 1940 a

Anon. $1960 \mathrm{~b}$

Anon. 1961

Anon. 1966 b

Anon. 1967 b

Anon. 1969

Anon. 1970 a

Anon. 1974 a

Anon. 1974 b

Anon. $1974 d$

Annin, J., Jr. 1897

Annin, J., Jr. 1898

Annin, J., Jr. 1899

Bean, T. H. 1897

Bean, T. H. 1907
Bean, T. H. 1908

Bean, T. H. 1910

Bishop, R. D. 1965 a

Bonin, J. D. 1976

Brice, J. J. 1898

Brown, R. R. 1910

Buie, G. D. 1963

Cernohous, L. 1974

Cheney, A. N. 1896

Cheney, A. N. 1898 a

Clark, T. L. 1974 a

Clark, T. L. 1974 b

Clark, T. L. 1975

Colesante, R. 1974

Cotchefer, R. 1902

Cotchefer, R. 1904

Coulloudon, J. et R. Couture 1961

Courtemanche, A., J.-R. Mongeau, G. Pageau et L. Deschamps MS 1963

Couture, R. et Y. Gravel MS 1962 a

Couture, R. et Y. Gravel MS 1962 b

Couture, R. et Y. Gravel 1965

Daley, S. A. 1974

Davis, H. S. 1953

Duerre, D. C. 1966

Dumas, R. F. 1972

Elson, P. F. 1940

Elson, P. F. 1941

Galat, D. L. and A. W. Eipper 1969

Galat, D. L. and A. W. Eipper 1975

Garland, C. 1973

Gibson, R. J. and E. J. Schindler 1969

Graff, D. R. 1968

Graff, D. R. and L. Sorenson 1970

Gravel, Y. et J. Guindon MS 1962

Gravel, Y. et J. Guindon 1965

Grey, J. 1974

Guindon, J. 1965

Hasler, A. D., R. K. Meyer and H. M. Field 1940

Hassan, K. C. and J. R. Spotila 1976

Hunt, J. M. 1966

Johnson, L. D. 1954 a

Johnson, L. D. 1954 d

Johnson, L. D. 1958 a

Johnson, L. D. and H. Laughlin 1955

Klingbiel, J., H. Laughlin and $M$.

Bachler 1959

Klingbiel, J. and A. A. Oehmcke 1958 
Lawrence, J. D. 1907 a

Lawrence, J. D. 1907 b

Leach, G. C. 1927

Mackay, H. H. and W. H. R.

Werner 1934

McKnight, T. 1974

Madden, K. M. and A. D. Lynch 1962

Moore, E. 1926

Mraz, D. F. 1962

Nevin, J. 1901

Norton, R. G. 1940

O'Donnell, D. J. 1945

Oehmcke, A. A. 1949

Oehmcke, A. A. 1951

Oehmcke, A. and K. Walker 1969

Oehmcke, A., K. Walker and $\mathrm{H}$. Laughlin 1969

Paladino, F. V. 1976

Papier, D. and R. Reithmiller 1958

Phillips, R. 1974 a

Phillips, R. 1974 b

Phillips, R. 1975

Phillips, R. and W. J. Graveen 1973

Pratt, K. 1975

Prévost, G. 1951

Prévost, G., ed. 1961

Prince, E. E. 1900

Radonski, G. 1964

Radonski, G. 1965

Raney, E. C. and D. A. Webster 1942

Robertson, J. 1969

Robertson, J. 1972

Roussow, G. 1953

Sanderson, C. H. 1969

Sanderson, C. H. 1974

Sanderson, C. H. and Z. Bean 1974

Schoettger, R. A. and E. W. Steucke, Jr. $\quad 1970$

Seagers, C. no date a

Seagers, C. no date b

Séguin, L.-R. MS 1950

Séguin, L.-R. MS 1951

Séguin, L.-R. 1952 a

Séguin, L.-R. 1952 b

Sorenson, L. MS 1970

Sorenson, L. 1971

Sorenson, L., K. Buss and A. D. Bradford 1966

Stroud, R. H. 1958
Threinen, C. W. 1958 b

Threinen, C. W. 1958 c

Trandahl, A. J. 1974

Tripp, S. 1965

Trombley, R. L. 1974

Wahl, R. M. 1958

Walker, K., S. Kmiotek and A. Oehmcke 1958

Walkinshaw, C. A. 1947

Webster, B. O. 1929

Webster, B. O. 1934

Williams, J. E. 1953

Williams, J. E. 1954 a

Dingell-Johnson Project Reports

Anon. 1958

Apgear, D. B. 1966

Baker, W. D. 1966

Beyerle, G. B. 1971

Beyerle, G. B. 1973

Bishop, R. D. 1965 a

Bishop, R. D. 1965 b

Bishop, R. D. 1966

Brewer, D. L. 1968 a

Brewer, D. L. 1968 b

Brewer, D. L. 1968 c

Brewer, D. L. 1969

Brewer, D. L. 1970 a

Brewer, D. L. $1970 \mathrm{~b}$

Brewer, D. L. 1970 c

Brown, E. H. 1962

Churchill, W. S. 1962 a

Churchill, W. S. 1962 b

Clark, C. F. 1964 b

Colesante, R. T. and R. EngstromHeg 1975

Duerre, D. C. 1966

Dumas, R. F. 1972

Engstrom-Heg, R. 1971

Engstrom-Heg, R. 1972

Erickson, J. 1966

Erickson, J. 1969

Fomey, J. L. 1969

Green, D. M., Jr. 1974

Green, D. M., Jr. 1975 a

Green, D. M., Jr. 1975 b

Hooper, F. F., J. E. Williams, M. H. Patriarche, F. Kent and J. C.

Schneider 1964 
Johnson, L. D. no date

Johnson, L. D. 1958 a

Johnson, L. D. 1961 a

Johnson, L. D. 1961 b

Johnson, L. D. 1962 a

Johnson, L. D. 1962 b

Johnson, L. D. 1962 c

Johnson, L. D. $1962 \mathrm{~d}$

Johnson, L. D. 1965 a

Johnson, L. D. 1965 b

Johnson, L. D. 1965 c

Johnson, L. D. $1965 \mathrm{~d}$

Johnson, L. D. $1965 \mathrm{e}$

Johnson, L. D. 1967 a

Johnson, L. D. 1967 b

Johnson, L. D. 1967 c

Johnson, L. D. $1967 \mathrm{~d}$

Johnson, L. D. 1967 e

Johnson, L. D. $1967 \mathrm{f}$

Johnson, L. D. 1967 g

Johnson, L. D. $1967 \mathrm{~h}$

Johnson, L. D. 1968 b

Johnson, L. D. 1968 c

Johnson, L. D. 1971 a

Johnson, L. D. 1971 b

Johnson, L. D. 1972 b

Johnson, L. D. 1974 b

Johnson, L. D. 1975 a

Kempinger, J. J. 1967 a

Kempinger, J. J. 1967 b

Kempinger, J. J. 1967 c

Kempinger, J. J. 1967 d

Kempinger, J. J. 1970

Kreil, A. L. 1969

Laarman, P. W. 1964

Miles, H. M. 1972

Miles, H. M., S. M. Loehner, D. T. Michaud and S. L. Salivar 1972

Miles, R. L. 1970

Miles, R. L. 1974

Morris, J., L. Morris and L. Witt 1972

Moseley, L. W. 1966

Mraz, D. F. 1962

Netsch, M. F. and W. L. Turner 1954

Orr, O. E. 1958

Parker, B. 1966

Parsons, J. W. 1955 a

Parsons, J. W. 1955 b
Pfitzer, D. W. 1952

Pritzer, D. W. 1954

Priegel, G. R. 1967

Roberts, K. R. 1964

Robinson, D. W. 1959

Robinson, D. W. 1964

Scholl, R. L. 1966

Smith, S. B. and D. M. Green, Jr. 1974

Snow, H. E. 1962

Snow, H. E. 1966

Snow, H. E. 1967 a

Snow, H. E. 1967 b

Snow, H. E. 1967 c

Snow, H. E. 1968 b

Snow, H. E. 1972

Sumner, R. E. 1968

Surber, E. W. 1966

Vasey, F. W. 1968

Vasey, F. W. 1972

Whitley, J. R. 1967

Williams, J. E. 1959 a

Williams, J. E. 1959 b

Williams, J. E. 1959 c

Williams, J. E. 1960

Williams, J. E. 1961 b

Williams, J. E. 1961 c

Williams, J. E. 1962

Williams, J. E. 1963

Williams, J. E. 1965 a

Williams, J. E. 1965 b

Williams, J. E. 1965 c

Williams, J. E. 1966

Williams, J. E. 1967

Williams, J. E. 1968

\section{Distribution and Range}

Anon. 1959

Anon. 1965

Anon. 1973

Becker, G. C. 1964 b

Becker, G. C. 1966

Becker, G. C. 1972

Bissett, E. D. R. 1927

Brewer, D. L. 1968 a

Cahn, A. R. 1927

Carlander, K. D. 1948

Cleary, R. E. 1956

Coulloudon, J. 1965 
Courtemanche, A. MS 1964

Courtemanche, A. et J.-R.

Mongeau 1965

Couture, R. 1972

Crossman, E. J. 1969

Cuerrier, J.-P., F. E. J. Fry et G. Préfontaine 1946

Dymond, J. R. 1922

Dymond, J. R. 1939

Dymond, J. R. 1947

Dymond, J. R., J. L. Hart and A. L. Pritchard 1929

Eddy, S., R. C. Tasker and J. C. Underhill 1972

Evermann, B. W. and E. L. Goldsborough 1907

Forbes, S. A. 1884

Friedrich, G. W. 1933

Fry, F. E. J. and V. B. Chapman 1948

Greeley, J. R. 1929

Greeley, J. R. 1938

Greeley, J. R. and S. C. Bishop 1932

Greeley, J. R. and C. W. Greene 1931

Green, D. M., Jr. 1974

Greene, C. W. MS 1934

Greene, C. W. 1935

Halkett, A. 1913

Harkness, W. J. K. and J. R. Dymond 1936 a

Harkness, W. J. K. and J. R. Dymond $1936 \mathrm{~b}$

Harkness, W. J. K. and F. E. J. Fry 1942

Hubbs, C. L. 1933

Hubbs, C. L. 1940

Hubbs, C. L. and D. E. S. Brown 1929

Hubbs, C. L. and K. F. Lagler 1949

Hubbs, C. L. and K. F. Lagler 1957

Johnson, M. and G. C. Becker 1970

Jordan, D. S. 1877 b

Jordan, D. S. 1878

Jordan, D. S. 1887 b

Jordan, D. S. 1905

Jordan, D. S. 1925

Jordan, D. S. 1929

Jordan, D. S. and H. E. Copeland 1877

Jordan, D. S. and B. W. Evermann 1963

Kirsch, P. H. 1894

Kirtland, J. P. 1838 a

Legendre, V. MS 1952 a
Legendre, V. MS 1952 b

Legendre, V. 1971

Liegey, F., E. H. Donahue and S. W. Eaton 1955

McAllister, D. E. 1968

McCormick, L. M. 1892

Moore, H. H. and R. A. Bream 1965

Nelson, E. W. 1884

Noland, W. E. 1951

Odell, T. T. 1932

Odell, T. T. and W. C. Senning 1938

Osbum, R. C. and E. L. Wickliff 1930

Oughton, J. P. MS 1930 a

Oughton, J. P. MS 1930 b

Paetz, M. J. and J. S. Nelson 1970

Patterson, D. L. 1953

Potvin, C. L. G. et A. Courtemanche 1968

Préfontaine, G. et J.-P. Cuerrier 1941

Prince, E. E. 1909

Radforth, I. MS 1941

Radforth, I. 1944

Richardson, L. R. 1938

Riddle, J. W., Jr. MS 1975

Ross, R. D. 1959

Rostlund, E. 1952

Scott, W. B. 1958

Scott, W. B. 1963

Scott, W. B. and E. J. Crossman 1967

Scott, W. B. and E. J. Crossman 1969

Scott, W. B. et E. J. Crossman 1974

Scott, W. B. and E. J. Crossman 1975

Seaman, E. A. 1948

Shuter, B. J. MS 1971

Simard, A. MS 1966

Small, H. B. 1883

Smith, C. L. 1962

Smith, H. M. and M.-M. Snell 1891

Smith, P. W. no date

Smith, S. B. and D. M. Green, Jr. 1974

Speirs, J. M. 1952

Srivastava, J. M. 1971

Sweigart, A. P. 1935

Toner, G. C. 1933

Toner, G. C. 1937

Van Meter, H. D. and M. B. Trautman 1970

Vincent, B. et V. Legendre 1974 
Welter, W. A. 1938

Whitaker, J. O., Jr. 1968

Young, J. K. 1970

\section{Food and Feeding Habits}

Anderson, L. R. 1948

Beyerle, G. B. 1971

Breder, C. M.. Jr. 1925

Cemohous, L. 1974

Couey, F. M. 1935

Coulloudon, J. 1965

Dube, J. A. and C. A. Rettie 1961

Dufour, M. 1965

Galat, D. L. and A. W. Eipper 1975

Gammon, J. R. 1963

Graff, D. R. and L. Sorenson 1970

Hourston, A. S. 1952

Hunter, G. W., 111 and J. S. Rankin, Jr. 1939

Johnson, L. D. no date

Johnson, L. D. 1954 a

Johnson, L. D. 1954 b

Johnson, L. D. 1961 a

Johnson, L. D. 1962 b

Johnson, L. D. 1965 b

Sanderson, C. H. 1969

Sanderson, C. H. 1974

Schmitz, W. R. and R. E. Hetfeld 1965

Trandahl, A. J. 1974

Wagner, C. C. and E. L. Cooper 1963

Weed, A. C. 1925

\section{Fossils}

Cavender, T. M. 1969

Cavender, T. M., J. G. Lundberg and R.

L. Wilson 1970

McAllister, D. E. 1959

McAllister, D. E. 1962

Pflieger, W. L. 1971

Smith, C. L. 1954

Smith, C. L. 1958

Smith, G. R. 1963

Wilson, R. L. 1967

\section{General Accounts}

Bridges, W. 1970

Buss, K. 1960
Carlander, K. D. 1969

Chamberland, R. B. 1946

Collins, H. H., Jr. 1959

Crossman, E. J. 1971

Cuvier, M. le B. et M. A. Valenciennes 1846

Dymond, J. R. 1964 a

Eddy, S. 1957

Eddy, S. and T. Surber 1960

Eddy, S. and J. C. Underhill 1972

Günther, A. 1880

Henshall, J. A. 1923

Hubbs, C. L. 1933

Jordan, D. S. and B. W. Evermann 1923

Karvelis, E. G. 1964

Kendall, W. C. 1919

Lagler, K. F. 1956

Langlois, T. H. 1954

Le Danois, E. no date

Lincoln, R. P. 1953

McClane, A. J., ed. 1951

McClane, A. J., ed. 1965

MacKay, H. H. 1931

Migdalski, E. C. 1962

Schrenkeisen, R. M. 1963

Séguin, L.-R. 1952 a

Séguin, L.-R. 1952 b

Smith, O. W. 1922 a

Van Oosten, J. 1946

Van Oosten, J. 1960

Vesey-Fitzgerald, B. and F. Lamonte, eds. no date

Walden, H. T., II 1964

\section{Habitat and Environmental Factors}

Anon. 1966 a

Bligh, E. G. 1971

Brewer, D. L. 1970 b

Ferguson, R. G. 1958

Fry, F., J.-P. Cuerrier et G.

Préfontaine 1941

Green, D. M., Jr. 1975 a

Jackson, M. F. and J. L.

Price MS 1949

Johnson, L. D. 1965 d

Johnson, L. D. 1967 b

Johnson, L. D. 1967 c

Johnson, L. D. $1967 \mathrm{~g}$ 
Johnson, L. $1968 \mathrm{~d}$

Johnson, L. D., J. H. Klingbiel, C. A. Wistrom and A. A.

Oehmcke MS 1957

Kleinert, S. J. and P. E. Degurse 1972

Lovett, R. J., W. H. Gutenmann, I. S. Pakkala, W. D. Youngs and D. J. Lisk 1972

Meek, S. E. and R. Newland 1886

Miles, H. M. 1972

Miles, H. M., S. M. Loehner, D. T. Michaud and S. L. Salivar 1972

Miles, H. M., S. M. Loehner, D. T. Michaud and S. L. Salivar 1974

Muir, B. S. MS 1957

Pageau, G. et L. Lévesque 1964

Pageau, G. et L. Lévesque 1967

Pageau, G., Y. Gravel and L. Lévesque 1971

Pfitzer, D. W. 1952

Pfitzer, D. W. 1954

Priegel, G. R. 1967

Ricker, W. 1964

Riddle, J. W., Jr. MS 1975

Smith, P. W. 1971

Threinen, C. W., C. Wistrom, B. Apelgren and H. Snow 1966

Walker, V. J. and D. R. Johnston 1962

\section{Hybrids}

Anon. 1952 b

Armbruster, D. 1966

Beyerle, G. B. 1973

Black, J. D. and L. O. Williamson 1947

Buss, K. 1961 b

Buss, K. 1966

Buss, K. and J. Miller 1967

Cameron, G. S. no date

Cameron, G. S. 1948

Clark, T. L. 1975

Crossman, E. J. and K. Buss 1965

Davisson, M. T. 1972

Dickinson, W. E. 1960

Eddy, S. 1940

Eddy, S. 1941

Eddy, S. 1944

Gibson, M. B. and J. W. MacPherson MS 1954

Godfrey, J., Jr. 1945
Graff, D. R. 1968

Jennings, T. L. and F. Frank 1965

Johnson, R. E. 1945

McCarraher, D. B. 1960

Nansen, C. 1973

Nikolyukin, N. I. 1963

Pratt, K. 1975

Raney, E. C. 1955

Sanderson, C. H. and Z. Bean 1974

Schwartz, F. J. 1972

Scott, D. P. 1964

Seaborn, E. 1937

Slastenenko, E. P. 1956

Slastenenko, E. P. 1957

Tennant, D. and G. Billy 1963

\section{Introduction and Stocking}

Anon. 1854

Anon. 1897 b

Anon. 1898

Anon. 1899

Anon. $1900 \mathrm{a}$

Anon. $1900 \mathrm{~b}$

Anon. $1900 \mathrm{c}$

Anon. $1900 \mathrm{~d}$

Anon. 1901

Anon. 1902 a

Anon. 1904

Anon. 1925

Annin, J., Jr. 1896

Annin, J., Jr. 1898

Annin, J., Jr. 1899

Ayres, W. O. 1854

Becker, G. C. 1964 a

Brown, E. H. 1962

Churchill, W. S. 1950

Churchill, W. S. 1962 b

Couture, R. et Y. Gravel MS 1962 b

Daley, S. A. 1974

Erickson, J. 1961

Fetterolf, C. M., Jr. 1957

Gall, J. 1973

Gammon, J. R. 1960

Gammon, J. R. MS 1961

Grey, J. 1974

Hacker, V. A. 1966

Hein, E. N. 1940

Helm, J. M. 1960 
Johnson. L. D. 1961 b

Johnson, L. D. $1962 \mathrm{~d}$

Johnson, L. D. $1965 \mathrm{e}$

Johnson, L. D. $1967 \mathrm{~d}$

Johnson, L. D. $1967 \mathrm{~h}$

Johnson. L. D. 1968 c

Johnson. L. D. 1969 a

Johnson, L. D. 1971 b

Johnson, L. D. 1972 b

Johnson, L. D. 1974 b

Johnson, L. D. 1974 c

Johnson, L. D. 1975 a

Johnson, L. D. 1975 b

Kempinger, J. J. 1967 b

Kempinger, J. J. 1967 d

Klingbiel, J. 1966

Klingbiel, J. and L. E. Morehouse 1954

McFadden, J. T. 1964

Madden, K. M. and A. D. Lynch 1962

Oehmcke, A. A. 1951

Paquet, G. 1972

Penney, L. 1968

Pflieger, W. L. 1971

Roberts, K. R. 1964

Simard, A. and E. Magnin 1968

Smith, H. M. 1896

Snow, H. E. 1967 b

Snow, H. E. 1968 a

Snow, H. E. 1968 b

Taylor, Z. 1966

White, M. O. and R. E. Gehres 1962

Williams, J. E. 1959 b

Williams, J. E. 1963

Williams, J. E. 1965 b

Williams, J. E. 1966

Williams, J. E. 1967

Williams, J. E. 1968

\section{Length-Weight Relationships}

Anon. 1960 a

Anon. 1964 b

Bernard, C. 1964

Boulenger, E. G. 1931

Courtemanche, A. MS 1963 b

Couture, R. 1964

Devitt, O. E. 1953

Devitt, O. E. 1958
Greeley, J. R. 1938

Harkness, W. J. K. 1945

Hourston, A. S. 1952

Johnson, L. D. 1960 a

Johnson, L. D. 1971 c

Krumholz, L. A. 1949

Schloemer, C. L. 1936

Simard, A. MS 1966

Spangler, G. R. MS 1966

Williams, J. E. 1961 a

Williamson, L. O. 1940 b

Young, J. K. MS 1971

\section{Life History and Habits}

Anon. no date a

Bean, T. H. 1908

Chamberland, R. B. 1946

Colesante, R. T. 1977

Crossman, E. J. MS 1954 b

Crossman, E. J. 1962 b

Ferguson, R. G. 1958

Fish, M. P. 1932

Flower, S. S. 1925

Forney, J. L. 1969

Galat, D. L. 1973

Galat, D. L. and A. W. Eipper 1969

Galligan, J. P. 1962

Gammon, J. R. 1961

Gammon, J. R. 1965

Goode, G. B. 1884

Johnson, L. D. 1966

Johnson, L. D., J. H. Klingbiel, C. A. Wistrom and A. A.

Oehmcke MS 1957

Kleinert, S. J. and D. Mraz 1966

MacGregor, J. M., J. A. Scott and B. C. Dean 1960

Miles, R. L. 1970

Miles, R. L. 1974

Needham, J. G. 1920

Oehmcke, A. A., L. Johnson, J. Klingbiel and C. Wistrom 1974

Parsons, J. W. 1959

Trautman, M. B. 1948

Trautman, M. B., and C. L. Hubbs 1935

\section{Management (general)}

Anon. 1907 b

Anon. 1938 


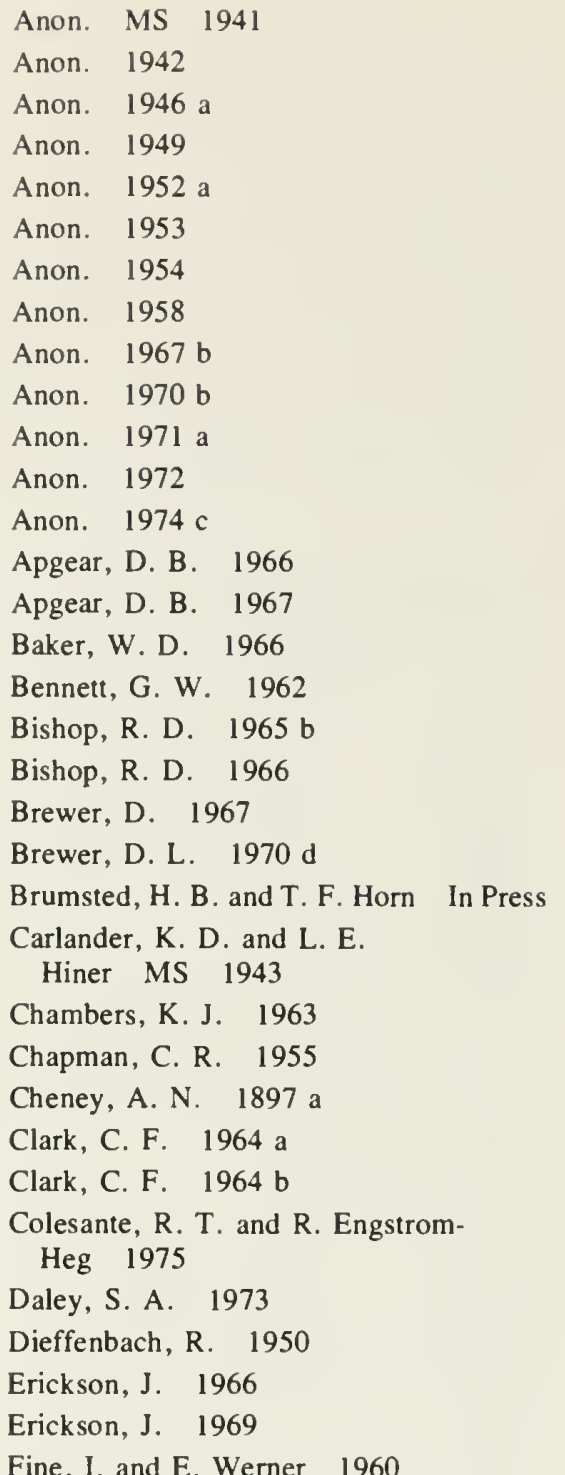

Fine, I. and E. Werner 1960

Gerking, S. R. and K. F. Lagler 1945

Hasse, J. J. MS 1976 a

Heacox, C. E. 1946

Hine, R. L., ed. 1961

Hooper, F. F., J. E. Williams, M. H. Patriarche, F. Kent and J. C.

Schneider 1964

Johnson, L. D. 1959

Johnson, L. D. 1960 b

Johnson, L. D. 1960 c

Johnson, L. D. 1968 a

Johnson, L. D. and D. K. Dunham 1956

Kempinger, J. 1969
Klingbiel, J. 1963

Kreil, A. L. 1969

Kuhne, E. R. 1938

Langlois, T. H. 1930

Langlois, T. H. 1945

MacGregor, J. M., J. A. Scott and B. C. Dean 1960

Mooradian, S. R. and W. F. Shepherd 1973

Moore, E. 1938

Moyle, J. B. and C. R. Burrows 1954

Muir, B. S. MS 1961 b

Oehmcke, A. 1969

Oehmcke, A. A. 1974

Oehmcke, A. A., L. Johnson, J. Klingbiel and C. Wistrom 1974

Parsons, J. W. 1958

Pelton, J. Z. 1956

Raney, E. C. MS 1941

Rathburn, R. and W. Wakeham 1897

Reithmiller, R. H. 1958

Riddle, J. W., Jr. MS 1975

Schrouder, J. 1973

Threinen, C. W. $1958 \mathrm{~d}$

Weir, J. C. 1955

Whitley, J. R. 1967

Williams, J. E. 1961 a

Williams, J. E. 1965 c

\section{Marking and Tagging}

Armstrong, A. E. MS 1963

Coulloudon, J. 1960

Crossman, E. J. MS 1954 b

Engstrom-Heg, R. 1971

Engstrom-Heg, R. 1972

McCleave, J. D. 1964

Muir, B. S. 1960

Muir, B. S. MS 1961 a

Muir, B. S. 1963 a

Muir, B. S. 1963 b

Muir, B. S. 1964

Muir, B. S. and J. G. Sweet 1963

Muir, B. S. and J. G. Sweet 1964

Patrick, B. and R. Haas 1971

Threinen, C. W. 1949

Walker, V. J. and D. R. Johnston 1962

Williamson, L. O. 1940 a 


\section{Parasites, Diseases, Pathology}

Ayles, H. 1970

Bangham, R. V. 1944

Bangham, R. V. 1955

Choquette, L. P. E. 1951

Colesante, R. 1974

Cooper, A. R. 1918

Davis, H. S. 1953

Dechtiar, A. O. 1972 a

Dechtiar, A. O. 1972 b

Dechtiar, A. O. 1972 c

Desrochers, R. and J. Coulloudon 1960

Fallis, A. M. 1964

Fantham, H. B., A. Potter and L. R. Richardson 1939

Fischthal, J. H. 1947

Fischthal, J. H. 1950

Fischthal, J. H. 1957

Hoffman, G. L. 1967

Johnson, L. D. 1954 a

Lincicome, D. R. and H. J. Van

Cleave 1949

McKnight, T. 1974

Mueller, J. F. 1938 a

Mueller, J. F. 1938 b

Nigrelli, R. F. 1954

Phillips, R. 1975

Ritchie, R. 1953

Roussow, G. 1953

Sonstegard, R. A. MS 1970 a

Sonstegard, R. A. 1970 b

Sonstegard, R. A. 1974

Sonstegard, R. A. and K. S.

Sonstegard 1973

\section{Physiology}

Allen, J. L., C. W. Luhning and P. D. Harman 1972

Atwater, W. O. 1885

Bonin, J. D. 1976

Hassan, K. C. and J. R. Spotila 1976

McCormick, N. A. 1924

Miles, H. M. 1972

Miles, H. M., S. M. Loehner, D. T. Michaud and S. L. Salivar 1972

Miles, H. M., S. M. Loehner, D. T. Michaud and S. L. Salivar 1974

Paladino, F. V. 1976
Schoettger, R. A. and E. W. Steucke, Jr. 1970

Scott, D. P. 1964

\section{Popular Accounts}

Anon. 1877

Anon. 1902 b

Anon. $1902 \mathrm{c}$

Anon. 1948

Anon. 1952 b

Anon. 1956

Anon. 1964 a

Anon. 1967 a

Anon. (Staff) 1971 b

Anon. $1971 \mathrm{c}$

Anderson, D. J. 1965

Anderson, L. A. 1966

Anderson, L. A. 1968

Anderson, L. A. 1971

Andrews, H. 1969

Armstrong, A. 1969

Armstrong, J. O. 1904

Balcerzak, R. 1972

Balcerzak, R. 1973 a

Balcerzak, R. 1973 b

Ball, M. 1954

Bashline, J. 1971

Bashline, J. 1973 a

Bashline, J. 1973 b

Baskett, J. N. 1899

Bauer, E. A. 1951 a

Bauer, E. A. 1951 b

Bauer, E. A. 1957 a

Bauer, E. A. 1957 b

Bauer, E. A. 1959

Bauer, E. A. 1961

Bauer, E. A. 1963 a

Bauer, E. A. 1963 b

Bauer, E. A. 1963 c

Bauer, E. A. 1965

Bauer, E. A. 1967

Bauer, E. A. 1970

Bauer, E. A. 1971

Bauer, E. A. 1973

Bauer, E. A. and P. Bauer 1970

Baysinger, B. 1969

Bean, T. H. 1891

Bean, T. H. 1899 
Becker, R. H. 1921

Bell, B. E. 1928

Bennington, J. C. 1959

Bergh, K. 1973

Bergman, R. 1958

Bonnycastle, D. 1906

Botsford, H. 1956

Bowers, R. R. 1958

Bradshaw, H. 1969

Branham, L. 1972

Bredemus, R. N. 1970

Brooks, J. 1970

Brown, A. 1971

Brown, E. 1969

Brown, E. 1971

Brown, J. J. 1876

Burch, R. T. 1967

Buss, K. 1965

Caine, L. S. 1949

Caine, L. S., ed. 1950

Campbell, D. 1958

Canfield, H. S. 1901

Carbine, W. F. 1938

Carhart, A. H. 1932

Carlander, K. D. 1952

Carlson, H. E. 1966

Cary, B. 1968

Castle, J. 1964

Chambers, E. T. D. 1904 b

Cheney, A. N. 1897 b

Cheney, A. N. 1898 b

Circle, H. no date

Circle, H. 1970

Claflin, B. 1943

Clark, G. 1955

Clarkson, E. P. 1963.

Clay, S. 1973

Collins, D. L. 1929

Crossman, E. J. 1975

Cull, J. L., ed. 1934

Davis, W. 1967

DeBoer, M. J. and J. R. Williams 1954

Derochers, J. 1895

Dickson, M. 1971

Dymond, J. R. 1932

Edson, O. 1909

Ellis, M. 1960

Ellis, M. 1964
Emery, A. R. 1974

Evermann, B. W. 1902

Evermann, B. W. 1906

Ewbank, E. L. 1916

Fichter, G. S. 1963

Foote, H. G. 1923

Foote, H. G. 1924

Fox, A. L. 1958

Fox, C. K. 1968

Fox, C. K. 1970

Fuller, B. 1970

Gabrielson, 1. N., ed. 1963

Gardner, K. 1971

Germain, U. E. 1919

Gibbs, J. 1974

Gilfillan, M. C. 1960

Glover, C. R. 1960

Goode, G. B. 1926

Gorham, C. 1974

Grahame, A. 1953

Gregory, M. 1971

Grosvenor, M. B., ed. 1969

Hacker, V. A. 1967

Hall, T. 1951

Hallock, C. 1877

Harkness, W. J. K. 1934

Harkness, W. J. K. 1936 a

Harkness, W. J. K. 1936 b

Harkness, W. J. K. 1936 c

Harkness, W. J. K. 1936 d

Harkness, W. J. K. $1936 \mathrm{e}$

Harkness, W. J. K. $1936 \mathrm{f}$

Harkness, W. J. K. and R. R. Langford 1936

Heacox, C. E. 1958

Heacox, C. E. 1971

Henshall, J. A. 1892

Henshall, J. A. 1904

Herald, E. S. 1961

Hobbs, R. G. 1892

Hoeft, B. 1970

Holder, C. F. no date

Howard, S. H., ed. 1942

Hvass, H. 1965

Janes, T. 1966

Jarvis, W. 1957

Jennings, P. 1957

Johnson, C. 1929 b 
Johnson, C. 1952

Johnson, L. D. 1954 b

Johnson, L. D. 1956 a

Johnson, L. D. $1960 \mathrm{~d}$

Johnson, L. D. $1960 \mathrm{e}$

Johnson, L. D. 1963

Johnson, L. D. $1965 \mathrm{f}$

Johnson. L. $1968 \mathrm{~d}$

Johnson, P. 1963

Jorgensen, W. and J. Jennings 1972

Jurgens, J. 1970

Karas, N. 1966

Karas, N. 1971

Keats, J. 1957

Kirtland. J. P. 1851

Kleeberg, G. S. P. 1924

Larson, V. 1964

Lawrence. H. L. 1967

Levy, H. M. 1962

Lind, J. A. 1964

Lindner, A. 1971

Lindner, R. 1971

Lindsey, A. J. 1970

Lucas, J. 1953 a

Lucas, J. 1959

Lucas, J. 1962

McClane, A. J. 1961

McIntosh, W. C. 1901

MacKay, H. H. 1956

MacQuarrie, G. 1953

Mann, J. 1955

Marshall, J. 1964

Mather, F. 1886 a

Mather, F. 1886 b

Maynard, P. 1970

Mullan, J. 1960

Mussey, W. P. 1897

Norris, T. 1864

Padgett, N. C. 1971

Papier, D. and R. Reithmiller 1958

Pasko, D. G. 1949

Pelton, J. Z. 1951

Penhale, B. 1961

Pierson, E. E. 1913

Pinkowski, B. 1961

Preuss, R. 1965

Rainey, D. 1968

Reddick, D. W. 1962 a
Reddick, D. 1962 b

Reece, M. 1963

Rhead, L. 1906

Rhead, L. 1923

Ricker, W. 1947

Roach, L. S. 1947

Roach, L. S. 1949

Samuels. H. J. 1969

Sandys, E. W. 1889

Sandys, E. W. 1902

Schneberger, E. 1946

Scott, G. C. 1875

Semotok, M. J. and L. Penney 1966

Sisley, N. 1971

Small, H. B. 1866

Smith, L. L., Jr. and N. L. Moe 1944

Snow, H. E. 1960

Sorenson, L. 1960

Sprecher, G. E. 1945

Stick, F. L. 1917

Stockwell, G. A. 1875

Stroud, R. H. 1957

Surface, H. A. 1900

Swanson, G. H. 1969

Tennant, D. 1954

Tennant, D., J. Mann and R.

Reithmiller 1953

Toner, G. C. no date

Trembley, G. 1964

Ulmann, A. 1921

Vigren, D. 1965

Waters, J. 1953

Whitehouse, F. C. 1948

Williams, J. E. 1948

Williams, J. E. 1959 a

Wolf, B. 1956

Wooding, F. H. 1959

Wooding, F. H. 1972

Woods, L. P. 1956

Zim, H. S. and H. H. Shoemaker 1956

Zwirz, B. 1967

\section{Population Studies}

Anon. 1955

Anon. 1960 a

Bernard, C. 1964

Bernard, C. 1967 
Buss, K. 1965

Courtemanche, A. MS 1963 a

Crossman, E. J. MS 1954 a

Crossman, E. J. 1956

Dursley, R. S. and F. E. J. Fry 1961

Erickson, J. 1961

Forney, J. L. 1969

Fry, F., G. Préfontaine et J.-P.

Cuerrier 1941

Green, D. M., Jr. 1975 b

Hacker, V. A. 1966

Hasse, J. J. MS 1976 a

Johnson, L. D. 1972 a

Johnson, L. D. 1974 a

Kempinger, J. J. 1967 a

Kempinger, J. J. 1967 c

Kempinger, J. J. 1970

Kempinger, J. J. 1972

Kempinger, J. J., W. S. Churchill, G. R. Priegel and L. M. Christenson 1975

Klingbiel, J. 1963

McCleave, J. D. 1964

Moseley, L. W. 1966

Muir, B. S. MS 1961 a

Muir, B. S. 1963 a

Muir, B. S. 1963 b

Muir, B. S. 1964

Muir, B. S. and J. G. Sweet 1963

Muir, B. S. and J. G. Sweet 1964

Netsch, M. F. and W. L. Turner 1954

Orr, O. E. 1958

Parsons, J. W. 1955 a

Parsons, J. W. 1955 b

Sheppard, W. 1968

Snow, H. E. 1962

Spangler, G. R. 1968

Vasey, F. W. 1968

Vasey, F. W. 1972

Weithman, S. 1975

Williams, J. E. 1961 b

Williams, J. E. 1962

\section{Predator-Prey Relationships}

Apgear, D. B. 1967

Buss, K. 1965

Churchill, W. S. 1950

Crossman, E. J. 1962 c

Dalrymple, B. 1968
Gammon, J. R. 1960

Gammon, J. and A. D. Hasler 1961

Gammon, J. and A. D. Hasler 1965

Oehmcke, A. A. 1951

Prince, E. E. 1912

Schmitz, W. R. and R. E. Hetfeld 1965

Smith, H. M. 1896

Snow, H. E. 1966

Snow, H. E. 1967 b

Snow, H. E. 1968 a

Snow, H. E. 1968 b

Taylor, Z. 1966

Threinen, C. W. 1959

Threinen, C. W. and A. Oehmcke 1952

Williams, J. E. 1965 a

Proteins, Enzymes, Electrophoresis

Drilhon, A., J.-M. Fine et E. Magnin 1961

Eckroat, L. R. 1974

Sexton, A. D. MS 1963

Uthe, J. R., E. Roberts, L. W. Clarke and H. Tsuyuki 1966

\section{Spawning (natural)}

Breder, C. M., Jr. and D. E. Rosen 1966

Brewer, D. L. 1969

Brewer, D. L. 1970 a

Burnett, W. I. 1854

Courtemanche, A., J.-R. Mongeau, G. Pageau et L. Deschamps MS 1963

Gammon, J. R. 1965

Garland, C. 1973

Johnson, L. D. 1967 e

Johnson, L. D. 1968 b

Penney, L. 1966

Penney, L. 1968

Préfontaine, G. et J.-P. Cuerrier 1941

Robinson, B. C. 1963 a

Sauve, J. and J. Fowler MS 1961

Wickliff, E. L. no date

Wickliff, E. L. 1933

Williams, J. E. 1954 b

Williams, J. E. 1961 a

Williams, J. E. $1961 \mathrm{c}$

Williamson, L. O. 1942 
Taxonomy, Nomenclature, Systematics

Anon. no date b

Anon. (E. M.) 1897 a

Anon. 1946 b

Agassiz. L. 1850

Bailey, R. M. 1956

Bailey, R. M., J. E. Fitch, E. S. Herald, E. A. Lachner, C. C. Lindsey, C. R.

Robins and W. B. Scott 1970

Beamish, R. J., M. J. Merrilees and E. J. Crossman 1971

Bean, T. H. 1881

Bean, T. H. 1897

Bean, T. H. 1902

Bean, T. H. 1903

Berg, L. S. 1936

Bishop, S. C. 1946

Boucher, P. 1964

Cameron, G. S. no date

Cavender, T. M., J. G. Lundberg and R.

L. Wilson 1970

Chambers, E. T. D. 1923

Cope, E. D. 1865

Cope, E. D. 1869

Crossman, E. J. 1960

Crossman, E. J. 1962 a

Crossman, E. J. and J. M. Casselman 1969

DeKay, J. E. 1842

Eckroat, L. R. 1974

Eddy, S. and A. C. Hodson 1951

Forelle, F. 1857

Fowler, H. W. 1918

Girard, C. 1854

Goode, G. B. 1879

Goode, G. B. and Associates, eds. 1884

Guillet, E. C. 1963

Günther, A. 1866

Henshall, J. A. 1920

Henshall, J. A. 1923

Herbert, H. W. 1864

Hourston, A. S. MS 1949

Hourston, A. S. 1955

Hubbs, C. L. and K. F. Lagler 1939

Jordan, D. S. 1877 a

Jordan, D. S. 1884

Jordan, D. S. 1887 a

Jordan, D. S. 1905
Jordan. D. S. 1923

Jordan, D. S. 1925

Jordan, D. S. 1929

Jordan, D. S. and B. W. Evermann 1923

Jordan, D. S. and B. W. Evermann 1963

Jordan, D. S., B. W. Evermann and H. W. Clark 1930

Jordan, D. S. and C. H. Gilbert 1882

Karvelis, E. G. 1964

Kirtland, J. P. 1847

Kirtland, J. P. 1854

Legendre, V. MS 1950

Legendre, V. MS 1952 a

Legendre, V. MS 1952 b

Legendre, V. 1953

Legendre, V. 1954 a

Legendre, V. 1954 b

Le Sueur, C. A. 1818

Lopinot, A. C. no date

Meek, S. E. and R. Newland 1886

Mellen, I. M. 1917

Merrilees, M. J. MS 1972

Merrilees, M. J. and E. J. Crossman 1974

Mosher, A. A. 1892

Nelson, G. J. 1969

Nikol'skii, G. V. 1961

Norman, J. R. 1966

Osburn, R. C. 1901

Prince, E. E. 1898

Prince, E. E. 1901

Richardson, J. 1836

Scott, W. B. and E. J. Crossman 1975

Seaborn, E. 1937

Sexton, A. D. MS 1963

Simard, A. MS 1966

Speirs, J. M. 1951

Speirs, J. M. 1953

Storer, D. H. 1972

Thompson, Z. 1851

Threinen, C. W. 1957 a

Weed, A. C. 1927

Whitaker, J. O., Jr. 1968

Wickliff, E. L. no date

Wickliff, E. L. 1933

Wright, R. 1892 



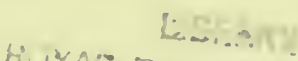

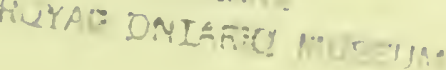



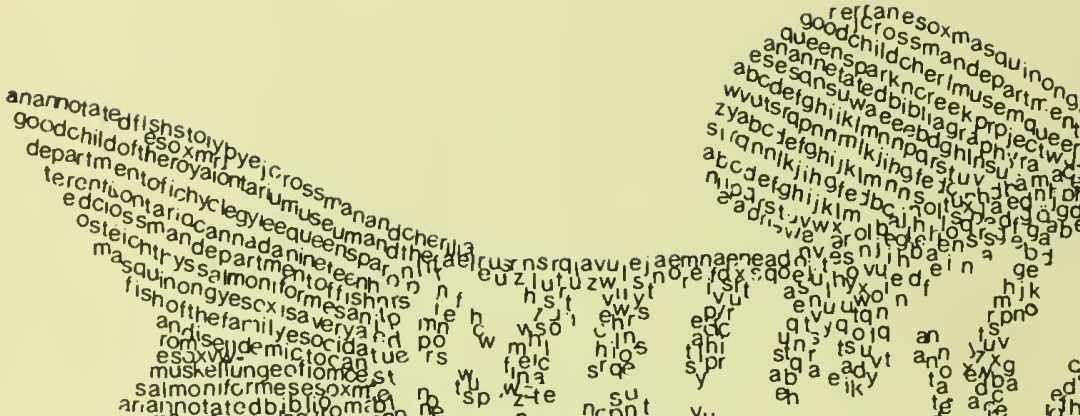

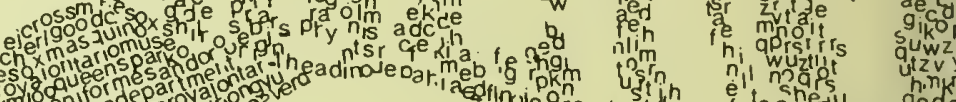

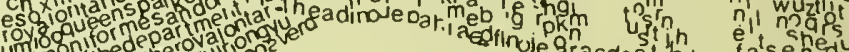
saimos of the atthersgut io are aracosis
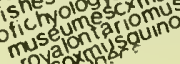